\title{
Republic of Mozambique: Poverty Reduction Strategy Paper-Economic and Social Plan for 2005
}

Poverty Reduction Strategy Papers (PRSPs) are prepared by member countries in broad consultation with stakeholders and development partners, including the staffs of the World Bank and the IMF. Updated every three years with annual progress reports, they describe the country's macroeconomic, structural, and social policies in support of growth and poverty reduction, as well as associated external financing needs and major sources of financing. This country document for the Republic of Mozambique, dated March 11, 2005, is being made available on the IMF website by agreement with the member country as a service to users of the IMF website.

To assist the IMF in evaluating the publication policy, reader comments are invited and may be sent by e-mail to publicationpolicy@imf.org.

Copies of this report are available to the public from

International Monetary Fund • Publication Services

$70019^{\text {th }}$ Street, N.W. • Washington, D.C. 20431

Telephone: (202) 623-7430 • Telefax: (202) 623-7201

E-mail: publications@imf.org • Internet: http://www.imf.org

Price: $\$ 15.00$ a copy

International Monetary Fund

Washington, D.C. 



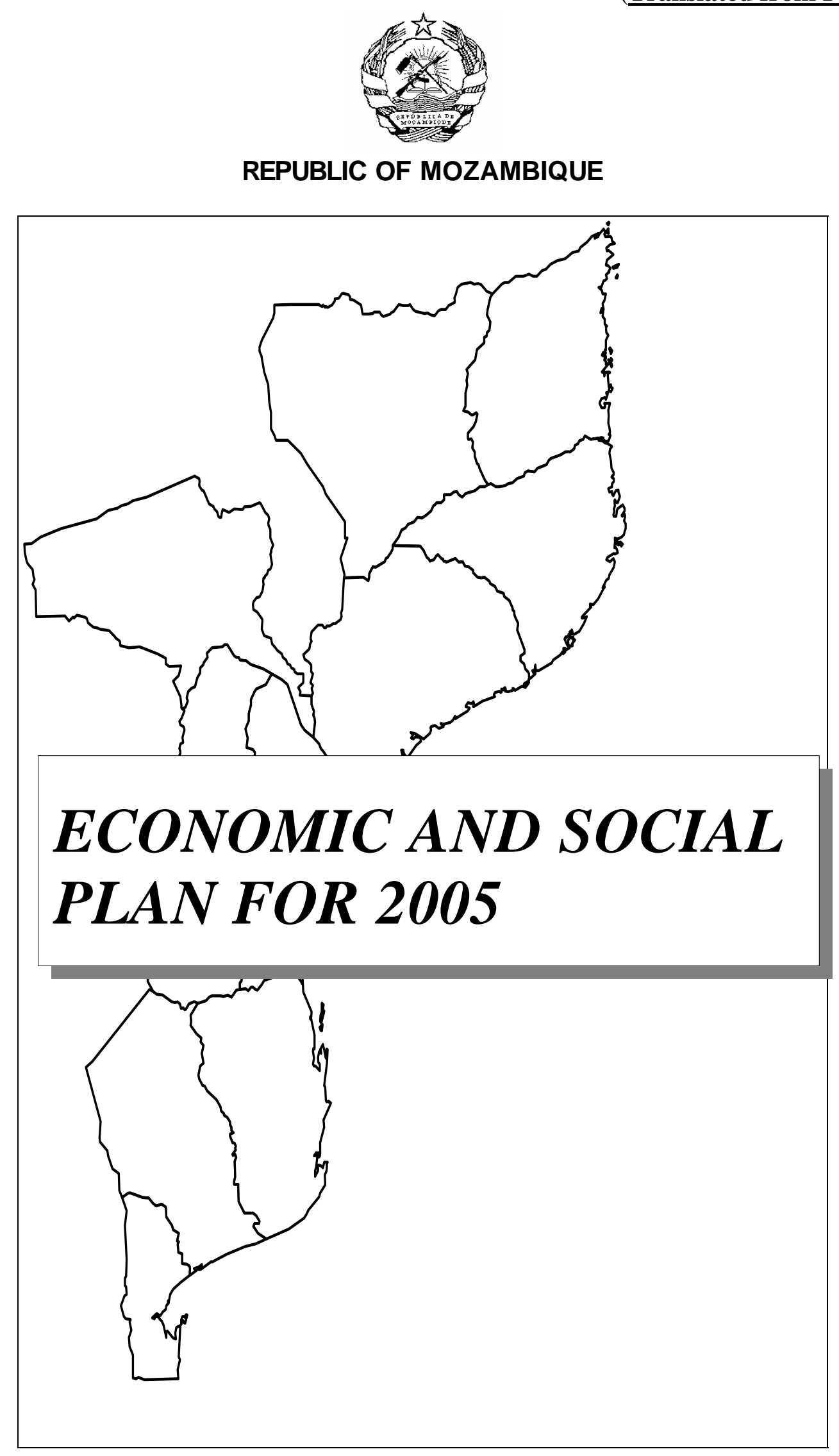

$11^{\text {TH }}$ of March 2005 


\section{CONTENTS}

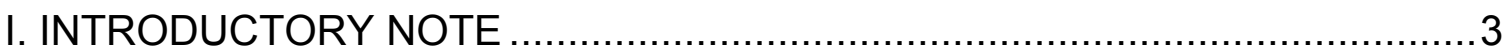

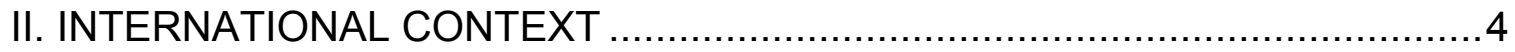

III. NATIONAL SOCIAL AND DEMOGRAPHIC CONTEXT ...........................

III.1 CENTRAL OBJECTIVES AND PRIORITIES OF THE GOVERNMENT .....7

III.2. MILLENNIUM DEVELOPMENT GOALS (MDGs) ................................

III.3. PROJECTIONS OF THE DEMOGRAPHIC AND MACRO-ECONOMIC

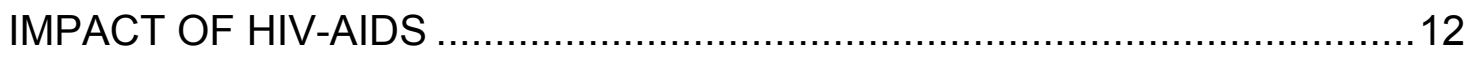

IV. MACROECONOMIC NATIONAL CONTEXT .......................................20

IV.1. OVERALL AND SECTOR PRODUCTION .....................................20

A. AGRICULTURE, LIVESTOCK AND FORESTRY .............................22

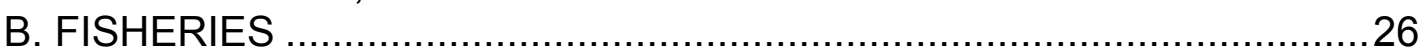

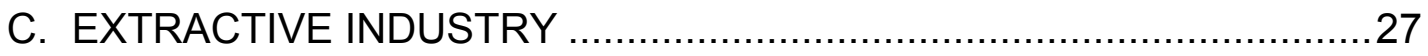

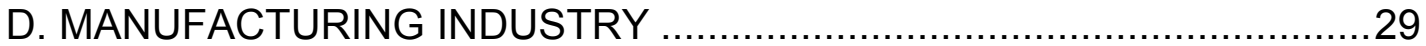

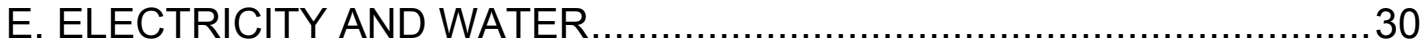

F. CONSTRUCTION

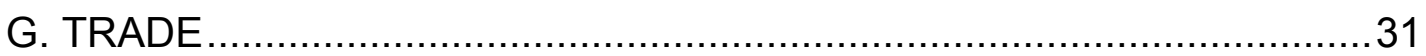

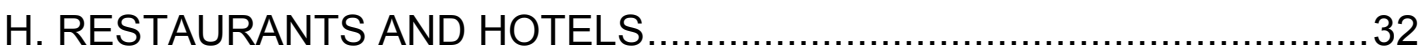

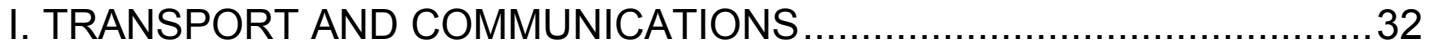

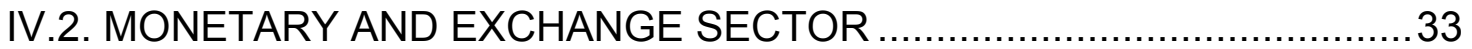

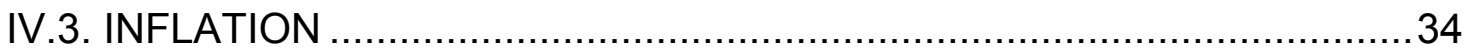

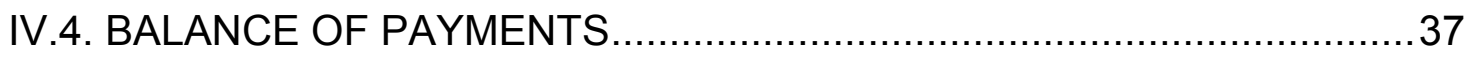

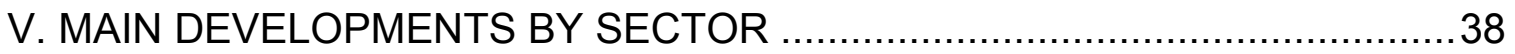

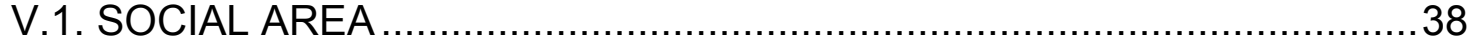

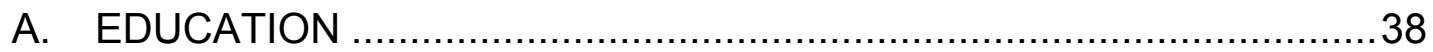

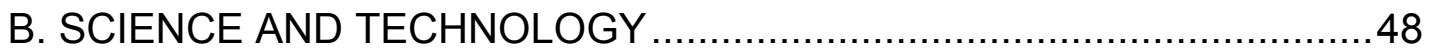

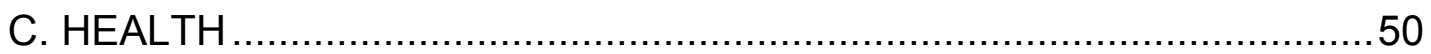

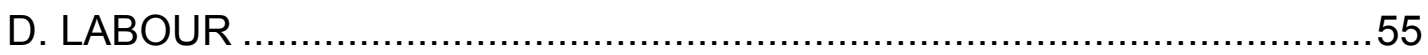

E. WOMEN'S AFFAIRS AND SOCIAL ACTION ................................5

F. VETERANS OF THE NATIONAL LIBERATION STRUGGLE ...............62

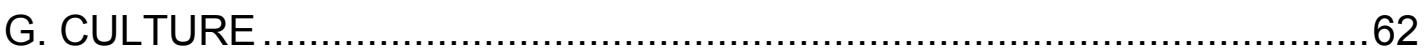

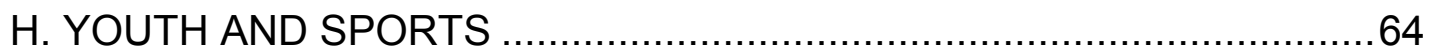

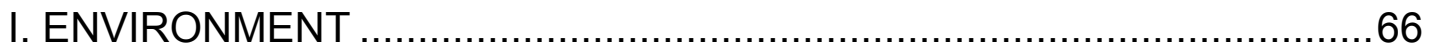

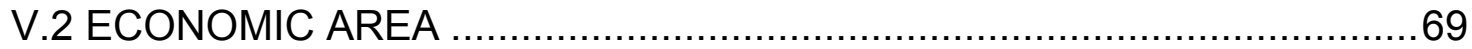

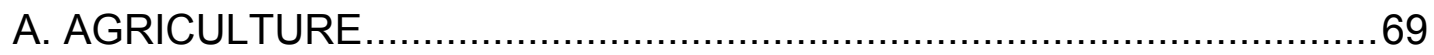

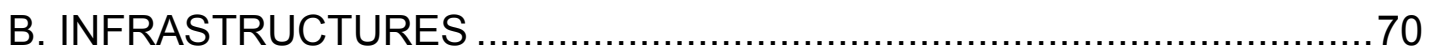

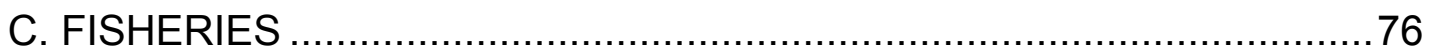

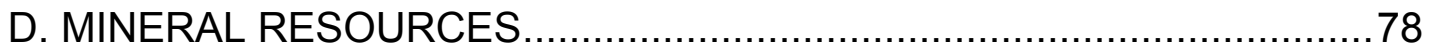

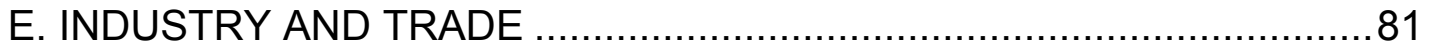

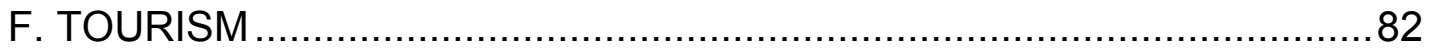

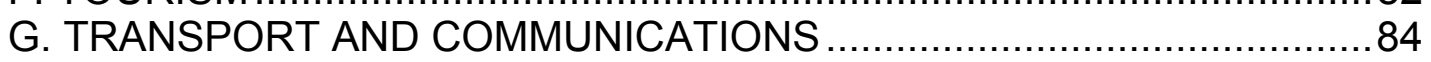

V.3. GOOD GOVERNANCE, LEGALITY AND JUSTICE,

DECENTRALISATION AND DECONCENTRATION ...................................... 86

V.4. FOREIGN RELATIONS AND DEFENCE .........................................93

APPENDIX 1 - REDUCED MATRIX OF MAIN INDICATORS .......................105 


\section{INTRODUCTORY NOTE}

The government's five year plan for the period 2005-2009 sets its main objectives as: (i) Reducing the levels of absolute poverty, which will be pursued through activities in education, health and rural development; (ii) Rapid and sustainable economic growth, focusing attention on the creation of an economic environment that favours private sector activity; (iii) The economic development of the country, aimed in the first place at the rural areas, and having in mind the reduction of regional imbalances; (iv) The consolidation of peace, national unity, justice, democracy and national awareness, as indispensable conditions for the harmonious development of the country; (v) The fight against corruption, crime and red tape; and (vi) The strengthening of sovereignty and international cooperation.

The current document, the Economic and Social Plan for 2005, is the first stage in making operational the government's five year programme for 2005-2009. With it, a new structure is being consolidated, one which was stated in the most recent documents drawn up, and which attempts to ensure better consistency between the various planning instruments as they interact.

Thus the current document consists of four major chapters: namely, International Context, National Macro-economic Context, Main Developments by Sector, and Budgetary Policy.

In the international context, the document presents the evolution of the international economy so as to understand under what economic conditions the country will have to implement its economic and social policy; the chapter on the national macroeconomic context presents the major macroeconomic objectives, and the evolution of the main economic indicators; the chapter on the main developments by sector presents the main policy measures to be implemented by the government, targets and activities. The chapter on budgetary policy presents the package of resources, their source and respective distribution in order to comply with the present Economic and Social Plan. Appended is a matrix of main indicators which makes it possible, in summary form, to assess the government's performance in key sectors. 


\section{INTERNATIONAL CONTEXT}

2003 ended with a recovery in the world economy (3.9\%). 2004 was characterised by a relatively sustainable performance by the world economy. It is estimated that growth reached about $5 \%$, one of the highest figures in the last 30 years, according to the International Monetary Fund (IMF). This growth is essentially due to the performance of the American and Asian economies, and particularly of Japan and China. Latin America also shows signs of recovery, and Africa is showing relatively good prospects.

Despite this recovery, as from the third quarter of 2004 there was a trend towards reduced growth, particularly in the USA, in Japan and in China, due to increased oil prices (in mid-August the price of a barrel was around 44.7 dollars). The risks facing us in 2005 are still linked to the behaviour of oil prices. Inflation risks are relatively low but there should be greater control over interest rates. The fiscal deficits in the advanced economies will continue to pose a challenge in 2005 , since these economies, taken together, had a fiscal deficit equivalent to $3.4 \%$ of their Gross Domestic Product (GDP).

According to recent estimates, made by the IMF and the OECD (Organisation for Economic Cooperation and Development), in 2005 the world economy will grow by almost $4.3 \%$. It is estimated that the growth in developing countries was $6.6 \%$ in 2004 , and will be $5.9 \%$ in 2005 . Africa was expected to reach a $4.5 \%$ growth rate in 2004 and $5.4 \%$ in 2005.

\begin{tabular}{|c|c|c|}
\hline & 2004 & 2005 \\
\hline World GDP Growth & 5.0 & $\overline{4.3}$ \\
\hline USA & 4.3 & 3.5 \\
\hline Japan & 3.4 & 2.3 \\
\hline Euro Zone & 2.2 & 2.2 \\
\hline Advanced economies & 3.5 & 2.9 \\
\hline Developing Countries & 6.6 & 5.9 \\
\hline Africa & 4.5 & 5.4 \\
\hline South Africa & 2.6 & 3.3 \\
\hline International Trade & 8.8 & 7.2 \\
\hline \multicolumn{3}{|l|}{ Imports } \\
\hline Advanced Economies & 7.6 & 5.6 \\
\hline Developing Countries & 12.8 & 11.9 \\
\hline \multicolumn{3}{|l|}{ Exports } \\
\hline Advanced Economies & 8.1 & 6.3 \\
\hline Developing Countries & 10.8 & 10.6 \\
\hline
\end{tabular}

Source: IMF, World Economic Outlook (October 2004); OECD, Economic Outlook (June 2004). 
Global international trade in goods and services will grow by about $9 \%$ in 2004 , and a growth of about $7 \%$ is forecast for 2005. Imports and exports, for 2005, both for the advanced and for the developing economies will present rhythms of growth at the levels of 2004, which are higher than those of 2003.

It is estimated that the GDP of the United States of America grew at a rate of $4.3 \%$, in 2004 , and the American economy is forecast to grow by $3.5 \%$ in 2005 . In 2004, the Federal Reserve Bank increased the interest rate (federal-funds) as a way of controlling inflation, taking into account the growth that is occurring. For 2005 , it is thought that investment will grow, as well as the external sector, particularly exports. Internal demand will also increase.

In Japan growth in 2004 is relatively high, and may reach a growth rate of above $3 \%$. For 2005 , the forecast is $2.3 \%$. This rate will be the result of continued high growth rates in exports at the levels of 2004, and a recovery, albeit moderate, in investment and domestic demand.

In the European Union, in the Euro zone GDP growth in 2004 is estimated at $2.2 \%$, and the same rate is projected for 2005 . Unemployment remains relatively high (9\% in 2004 and $8.7 \%$ in 2005). A recovery of non-residential investment and also of private consumption is forecast for 2005.

The GDP growth rate in South Africa for 2004 is estimated at 2.6\%, and the 2005 forecast is $3.3 \%$.

Zimbabwe recorded a negative growth rate in 2003 of $-9.3 \%$. The estimate for 2004 is $-5.2 \%$, and for 2005 the IMF forecasts a growth rate of $1.8 \%$. In 2003 inflation was about $431.7 \%$, in 2004 about $350 \%$, and for 2005 an inflation rate of around $450 \%$ is forecast.

The terms of trade for the advanced economies show a certain stagnation in the 2004-2005 period. The table below shows the growth rate of the Consumer Price Index for 2004-2005. In the advanced economies, there will tend to be price stability at relatively low inflation levels $(2.1 \%)$, while in the developing economies, inflation is estimated at between 5.5 and $6 \%$. In Africa inflation will be around $8 \%$.

It is forecast that interest rates in the most developed economies will tend to rise slightly, as a way of holding back potential inflation risks, given that these economies have been recovering. 
$-6-$

ECONOMIC AND SOCIAL PLAN FOR 2005

\begin{tabular}{|c|c|c|}
\hline \multicolumn{3}{|c|}{ PERCENTAGE FORECASTS } \\
\hline & 2004 & 2005 \\
\hline \multicolumn{3}{|l|}{ Terms of Trade } \\
\hline Advanced Economies & 0.1 & 0.6 \\
\hline Developing Countries & 3.2 & -0.3 \\
\hline \multicolumn{3}{|l|}{ Prices in dollars } \\
\hline Manufactured goods & 7.5 & 1.5 \\
\hline Oil & 28.9 & \\
\hline Commodities & 16.8 & -3.9 \\
\hline \multicolumn{3}{|l|}{ Inflation } \\
\hline USA & 3.0 & 3.0 \\
\hline Euro Zone & 2.1 & 1.9 \\
\hline Advanced Economies & 2.1 & 2.1 \\
\hline Developing Countries & 6.0 & 5.5 \\
\hline Africa & 8.4 & 8.1 \\
\hline
\end{tabular}

\begin{tabular}{|l|r|r|}
\hline & 2004 & 2005 \\
\hline Short term interest rates & & \\
\hline USA & 1.5 & $2.5-3.0$ \\
\hline United Kingdom & 4.9 & $4.9-5.3$ \\
\hline Euro Zone & 2.1 & $2.2-2.7$ \\
\hline Japan & 0.0 & 0.0 \\
\hline Advanced Economies & 1.9 & $1.9-2.5$ \\
\hline & & \\
\hline Unemployment & & \\
\hline USA & 5.5 & 5.4 \\
\hline Japan & 4.7 & 4.5 \\
\hline Euro Zone & 9.0 & 8.7 \\
\hline Advanced Economies & 6.3 & 6.1 \\
\hline \hline
\end{tabular}

For 2005, unemployment rates in the advanced economies are forecast to decline slightly compared with 2004 levels. This is an indication that the recovery, in terms of job creation, of the world economy still faces some challenges in 2005.

These forecasts point to an international economic scenario for 2004-2005 in which a relatively sustainable recovery occurs, but where it is still necessary to ensure that growth is more balanced in the various regions of the world. There are still some risks to be considered: oil prices, and the fiscal deficits of the developed economies. 


\section{NATIONAL SOCIAL AND DEMOGRAPHIC CONTEXT}

\section{III.1 CENTRAL OBJECTIVES AND PRIORITIES OF THE GOVERNMENT}

In the five year period 2005-2009, the government will continue the efforts under way, concentrating its activity on pursuing the following objectives:

- Reducing the levels of absolute poverty, which will be pursued through promoting rapid, sustainable and wide ranging economic growth, focusing attention on creating an environment favourable to investment and the development of the national business class, and through activities in education, health and rural development;

- The economic and social development of the country, oriented in the first place to the rural areas, having in mind the reduction of regional imbalances;

- The consolidation of National Unity, Peace, Justice and Democracy, as well as citizens' spirit of self-esteem, as indispensable conditions for the harmonious development of the country;

- Valuing and promoting the culture of work, enthusiasm, honesty and accountability;

- The struggle against corruption, red tape and crime;

- The strengthening of Sovereignty and International Cooperation.

Poverty reduction is a challenge for everyone and a fundamental condition for promoting human, economic and social development, in the countryside and in the cities.

This vision includes objectives that may be reached in the short, medium and long terms, enshrined in the national development plans, and in the strategies for fighting poverty and HIVIAIDS, as well as in programmes of regional, continental and international scope, with greatest stress on the New Partnership for Africa's Development (NEPAD) and the Millennium Development Goals (MDGs).

The objective of reducing the levels of absolute poverty presupposes the priority channelling of basic services to the neediest strata of the population.

Hence the main activity of the government will be oriented to improving the living conditions of the majority of our population, which consists of women. Thus women will be at the centre of attention, seeking to ensure that they enjoy 
equality of opportunity and rights, raise their educational level and strengthen their role as educators of future generations, as regards shaping the personality of Mozambicans.

Since the majority of the population in the rural areas still lives in extreme poverty, the government will pay greatest attention to promoting actions that seek the accelerated and sustainable development of the rural areas, and will multiply initiatives aimed at creating wealth in the countryside, as its fundamental strategy in the struggle against poverty.

The government regards the market economy as one of the catalysts for speeding up the country's sustainable economic development. To this end, it will continue implementing actions seeking rapid and multi-sector development in all parts of the country. The harmonious development of the country will be supported by the establishment of conditions for increasing investment and for the flowering of the private sector.

The government fights for good governance, based on the principles of participation in decision making, transparency in the management of the public domain and regular accountability. Thus, corruption and its expressions, which form a phenomenon that blocks the country's social and economic development, will be fought against, with resort to political, penal and judicial measures.

The government will continue establishing conditions for strengthening our sovereignty through strengthening the security of the state, of the economy, and of the defence of citizens' interests.

The government shall also continue to deepen bilateral and multilateral cooperation with all partners and friends, as well as tightening the bonds of international cooperation in order to consolidate Mozambique's integration into regional and international blocs.

Special attention will also be paid to Mozambicans in the diaspora, since they are an integral part of Mozambican society, and enjoy the same constitutional rights and duties.

The reduction of absolute poverty, through promoting social and economic development, includes, among others, the following components:

- Transformation of the socio-demographic characteristics so as to reproduce a substantially better educated and healthy population, consisting of citizens who are better prepared to face the challenges of a dynamic world. Among a population that is on average better educated, and more employable, one should note a significant segment of people endowed with initiative, with 
innovative and entrepreneurial capacity, and who may stimulate the appearance and development of institutions, particularly dynamic companies, of all sizes.

- Development and provision of basic infrastructures (physical, and concerned with the development of applied technological research and extension), and institutional infrastructures that make viable the flourishing of private initiative and investment (national and foreign) on a broad and inclusive base, creating a solid, sustainable and competitive economy in the context of normal insertion into the world market.

For pursuing the objectives of the government programme, key areas for action are the following:

- Education

- Health

- Infrastructures

- Agriculture

- Rural Development

- Good Governance, Legality and Justice

- Macro-economic, Financial and International Trade Policies

\section{III.2. MILLENNIUM DEVELOPMENT GOALS (MDGs)}

The Economic and Social Plan is an important instrument for assessing the country in respect of attaining the Millennium Development Goals (MDGs). The present draft Economic and Social Plan takes the Millennium Development Goals into consideration. These targets are a series of objectives for human development that were established under the Millennium Declaration, which was signed in September 2000 by 147 countries. There exist the following MDGs to be attained by 2015 :

- Eradicate extreme poverty and hunger;

o Achieve universal primary education;

o Promote gender equality and empower women;

o Reduce child mortality;

o Improve maternal health;

o Combat HIVIAIDS, malaria and other diseases;

o Guarantee environmental sustainability; 
o Develop a global partnership for development.

For each objective the United Nations has designed specific targets that can be monitored through quantitative indicators. However, it has been necessary to adjust these targets in the national context to monitor the level of Mozambique's performance in the context of the MDGs. For example, the indicators suggested by the United Nations cannot always be collected annually, so that in these cases indicators more appropriate for the case of Mozambique are chosen.

\section{Eradicate Extreme Poverty and Hunger}

A global MDG target with the objective of cutting by half the percentage of people living in extreme poverty or suffering from hunger, between 1990 and 2015. It should be noted that the targets established in PARPA are, in general, consistent with the MDG targets.

Out of a population estimated at 18.3 million, almost 10 million are still poor. In future, while poverty measured by consumption is an integral component of a multi-dimensional concept of poverty, some attention should be directed to aspects of poverty such as access to public services, which are not directly measured through household surveys based on consumption.

\section{Combat HIVIAIDS}

One of the MDGs is to halt, and begin to reduce, by 2015, the spread of HIVIAIDS. In order to understand the true scale and geographical distribution of the HIVIAIDS problematic, studies have been held into the prevalence and the demographic and macro-economic impact of this pandemic.

To attain this objective, in 2005 action will remain concentrated on the treatment of opportunistic infections, on providing advice about forms of prevention, on supplying anti-retroviral drugs to 25,000 people, including 15,000 pregnant women, and on providing home care to patients with HIVIAIDS. It is expected that in 2005 the HIV prevalence rate among adults will reach $15.6 \%$.

\section{Basic comforts}

One of the MDGs is to cut the proportion of people without access to clean drinking water by half, by 2015. In 1992, according to the statistics of the Public Works and Housing sector, $10 \%$ of rural households had access to safe drinking water, while in 2003 the figure was $39.4 \%$ of households. In urban areas, the rate of growth has been slower, from $29 \%$ in 1991 to $33.3 \%$ in 2003. An important factor associated with this situation is rapid migration. Thus, although the absolute number of individuals in the urban areas who have access to safe drinking water has increased considerably, the coverage has increased more slowly, when viewed as a percentage of the urban population. However, as a 
result of the new urban water and sanitation project in several cities, this number should grow rapidly.

\section{Universal Primary Education}

One of the MDGs is to achieve universal access to primary education by 2015 . Universal primary school enrolment remains a major challenge for Mozambique.

To achieve this goal, efforts in 2005 will remain concentrated on expanding access and improving the quality of education. Thus, it is envisaged that the net enrolment rate in EP1 will rise from the current $75.6 \%$ to $79 \%$ and that the gross admission rate will increase by $19.1 \%$ rising from the current $137.6 \%$ to $156.7 \%$. In terms of improving the quality of education, the new national curriculum will be introduced in 2nd, 4th and 7th grades; the new curriculum will be adopted in the teacher training institutions (CFPP and IMAP) and the free distribution of school textbooks and other educational material will continue.

\section{Gender equality}

One of the MDGs is to eliminate gender inequality in primary and secondary education, preferably by 2005 , and in all levels of education by 2015 at the latest. In recent years the gender gap in primary education has decreased notably. The Education Strategic Plan proposes increasing access to education, with special stress on girls' education. Apart from this, there are programmes such as "Ratio for Girls" which make a major effort to increase the number of female teachers. If current trends persist, it is likely that the objective of reaching gender parity in education will be achieved in first level primary education in 2005, or shortly afterwards.

\section{Reduce child mortality}

A further MDG is to reduce mortality among under fives by two thirds by 2015 . To attain this MDG, Mozambique needs to reduce the mortality rate among children under five from 277/1,000 live births in 1994 to 82/1,000 live births in 2015. The Expanded Vaccination Programme forms part of the government's efforts in this area. The PARPA objective for 2005 of $98 \%$ coverage of BCG (against tuberculosis) was already achieved in 2003. However, much effort is still needed to raise the coverage rate of the DTP (3) vaccination.

As part of the effort to reduce child mortality, vaccination activities will be undertaken for children aged 0-23 months, children in the first grades of school, and women of child-bearing age (15-49 years). Thus it is expected to reach a $98 \%$ coverage rate of the BCG vaccine, $98 \%$ coverage of the VAS vaccine, and $95 \%$ coverage of DPT (3). 


\section{Improve maternal health}

Reducing maternal mortality by three quarters by 2015 is one of the MDGs. A central component of the Strategic Health Plan and of PARPA is the Mother and Child Health and Family Planning Programme (SMI/PF). The PARPA target of cutting the hospital rate of maternal mortality from 175 per 100,000 in 2000 to 160 in 2005 can be achieved.

In order to improve maternal health, implementation of the Mother and Child Health and Family Planning Programme will continue. Thus a reduction in the hospital maternal mortality rate to $0.16 \%$ is expected. Institutional births and family planning (new users) should reach coverage rates of $49 \%$ and $20 \%$, respectively.

\section{Combat malaria}

One MDG is to halt, and begin to reverse, by 2015 , the incidence of malaria and other significant diseases. Prevention programmes are common and effective treatment in hospital continues to be followed closely.

To combat malaria, the use of insecticide treated mosquito nets will be promoted, spraying with insecticides will be undertaken where recommended, and cases of fever will be treated in the community in accordance with the habits prevailing in the communities. Thus it is expected to reach in 2005 a hospital malaria lethality rate in children and in adults of $2.7 \%$ and $5.3 \%$, respectively.

\section{Environmental sustainability}

A further Millennium Development Goal is to integrate the principles of sustainable development into the country's programmes and policies, and reverse the loss of environmental resources.

To achieve this goal, in 2005 priority will be given to publicising the Environmental Strategy for the Sustainable Development of Mozambique, to actions raising awareness of environmental issues, and to the formulation and implementation of specific environmental management policies/programmes.

\section{III.3. PROJECTIONS OF THE DEMOGRAPHIC AND MACRO- ECONOMIC IMPACT OF HIV-AIDS}

The projection for the size of the Mozambican population in 2005 is $19,420,036$ inhabitants, 10,051,611 women and 9,368,425 men with a dependency rate of $86.2 \%$. 
After the information published from the 2002 epidemiological surveillance round, the Multi-Sector Technical Support Group for the Fight against HIVIAIDS updated the information on the demographic impact of HIVIAIDS in Mozambique in order to better guide the initiatives of all stakeholders in the struggle against HIVIAIDS.

The table below presents the national HIV prevalence rate among the adult population (aged between 15 and 49). If the historical pattern is followed, without immediate and effective intervention, by 2010 the prevalence rate will reach $16.8 \%$.

\section{Graph : National Prevalence of HIV in Adults (15 - 49 years)}

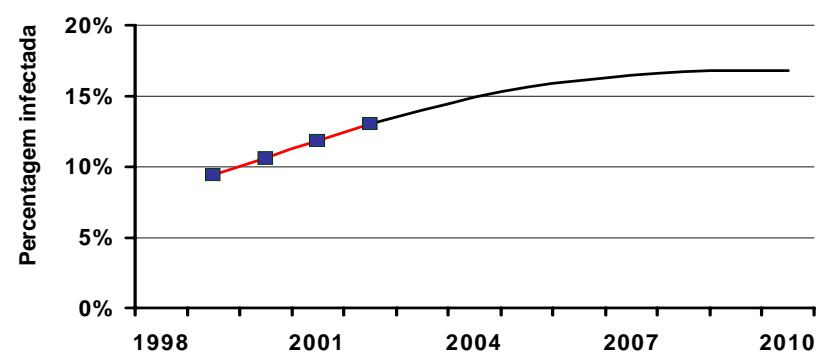

Table: HIVIAIDS prevalence among adults (15-49 years), by region and nationally

\begin{tabular}{|l|l|l|l|l|}
\cline { 2 - 5 } \multicolumn{1}{c|}{} & \multicolumn{4}{c|}{ Both Sexes } \\
\cline { 2 - 5 } \multicolumn{1}{c|}{} & South & Centre & North & National \\
\hline $\mathbf{1 9 9 8}$ & $8.2 \%$ & $12.2 \%$ & $3.2 \%$ & $8.2 \%$ \\
$\mathbf{1 9 9 9}$ & $9.9 \%$ & $13.3 \%$ & $4.1 \%$ & $9.4 \%$ \\
$\mathbf{2 0 0 0}$ & $11.6 \%$ & $14.2 \%$ & $5.3 \%$ & $10.6 \%$ \\
$\mathbf{2 0 0 1}$ & $13.2 \%$ & $15.0 \%$ & $6.8 \%$ & $11.8 \%$ \\
$\mathbf{2 0 0 2}$ & $14.5 \%$ & $15.7 \%$ & $8.4 \%$ & $13.0 \%$ \\
$\mathbf{2 0 0 3}$ & $15.6 \%$ & $16.2 \%$ & $10.0 \%$ & $14.0 \%$ \\
$\mathbf{2 0 0 4}$ & $16.4 \%$ & $16.7 \%$ & $11.5 \%$ & $14.9 \%$ \\
$\mathbf{2 0 0 5}$ & $16.9 \%$ & $17.0 \%$ & $12.8 \%$ & $15.6 \%$ \\
$\mathbf{2 0 0 6}$ & $17.2 \%$ & $17.3 \%$ & $13.8 \%$ & $16.1 \%$ \\
$\mathbf{2 0 0 7}$ & $17.3 \%$ & $17.5 \%$ & $14.6 \%$ & $16.5 \%$ \\
$\mathbf{2 0 0 8}$ & $17.3 \%$ & $17.6 \%$ & $15.1 \%$ & $16.7 \%$ \\
$\mathbf{2 0 0 9}$ & $17.2 \%$ & $17.7 \%$ & $15.4 \%$ & $16.8 \%$ \\
$\mathbf{2 0 1 0}$ & $17.1 \%$ & $17.7 \%$ & $15.5 \%$ & $16.8 \%$ \\
\hline
\end{tabular}


In 2004, in the south, the lowest prevalence rate is recorded in Inhambane province $(8.6 \%)$, and no great differences are noted between the prevalence rates in Maputo City (17.3\%), Maputo Province (17.4\%) and Gaza (16.4\%). In the Centre, Sofala province has the highest prevalence rate $(26.5 \%)$ followed by Manica with $19 \%$, Tete with $14.2 \%$ and Zambézia with $12.5 \%$, while in the north, Niassa province $(11.1 \%)$ shows the highest prevalence, followed by Nampula (8.1\%) and Cabo Delgado (7.5\%).

In terms of the number of people living with HIVIAIDS in Mozambique, the projections indicate that about 1.4 million people were infected with the virus in 2004. Of these, 68,000 are children (0-4 years), 529,000 are men (15-49 years) and 779,000 are women (15-49 years).

\section{Projection of number of people living with HIVIAIDS}

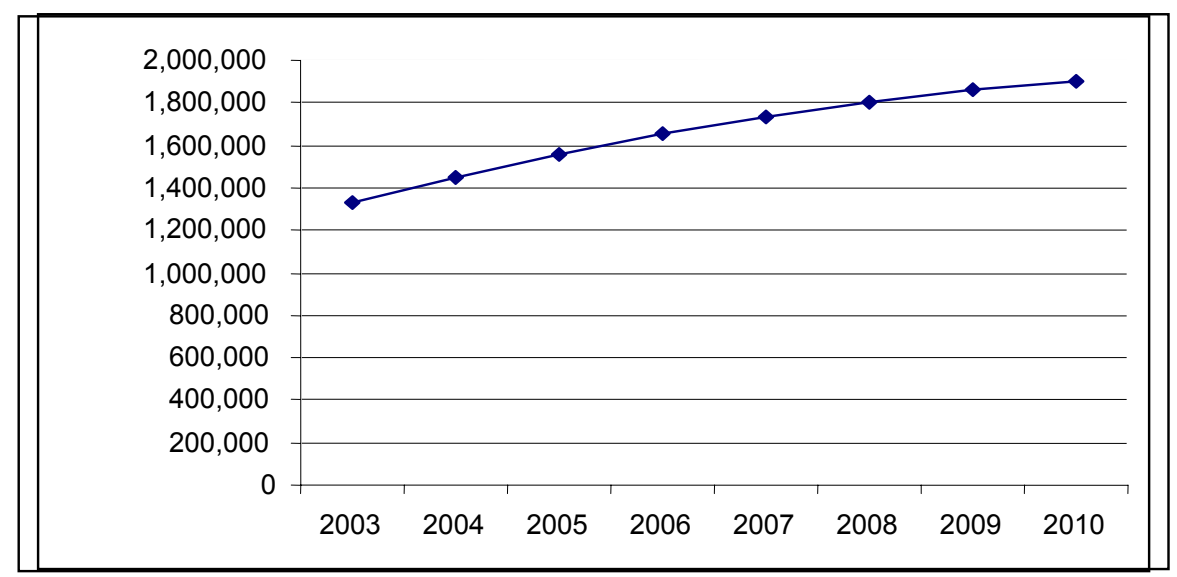

To calculate the projection of new cases of AIDS it must be borne in mind that the period from infection with HIV until the development of full-blown AIDS varies with age. Normally this period is shorter in children than in adults, with a median of 1 and 8 years respectively. It is estimated that 500 people are newly infected with HIV every day. The majority of new cases of AIDS will occur among people who are currently HIV positive. According to the projections, the number of new cases of AIDS might reach 178,084 by 2010 if there are no effective interventions. 


\section{Graph: New Cases of AI DS}

1999-2010

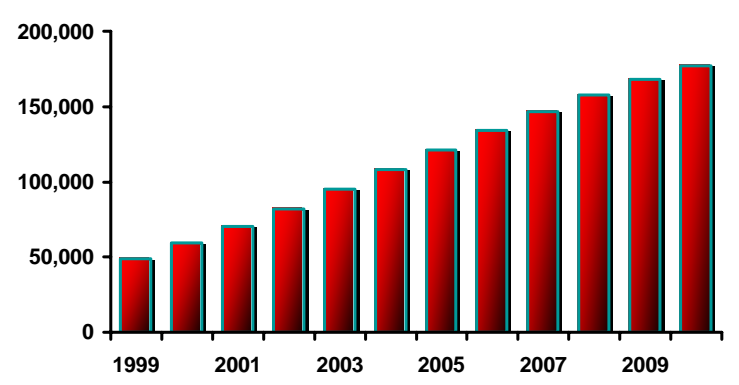

In a short time AIDS has become one of the main causes of death in Mozambique. The graph below shows the accumulated deaths due to AIDS. From this graph it can be seen that in just 5 years, from 1999 to 2003, 309,814 people died from AIDS. The number of deaths estimated for 2004 is 97,079 . It is important to stress that this mortality is differentiated by regions. About $58 \%$ of the deaths happened in the Central region of the country. The fact that this region is so much worse hit than the other regions may be explained by factors such as the larger size of the population, and the earlier start of the epidemic. It is forecast that in the next 7 years, the number of deaths from AIDS in Mozambique will triple, even with the expansion of ARV therapy.

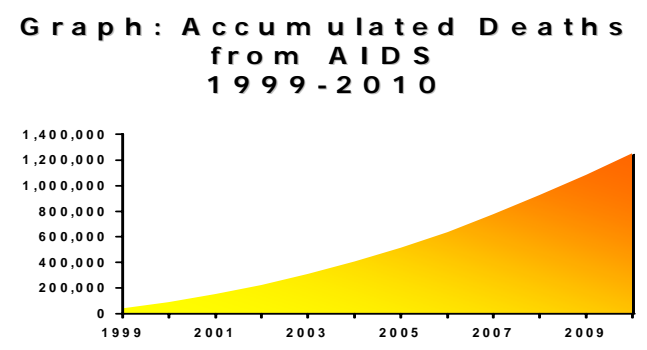




\section{Projection of the number of deaths from HIVIAIDS}

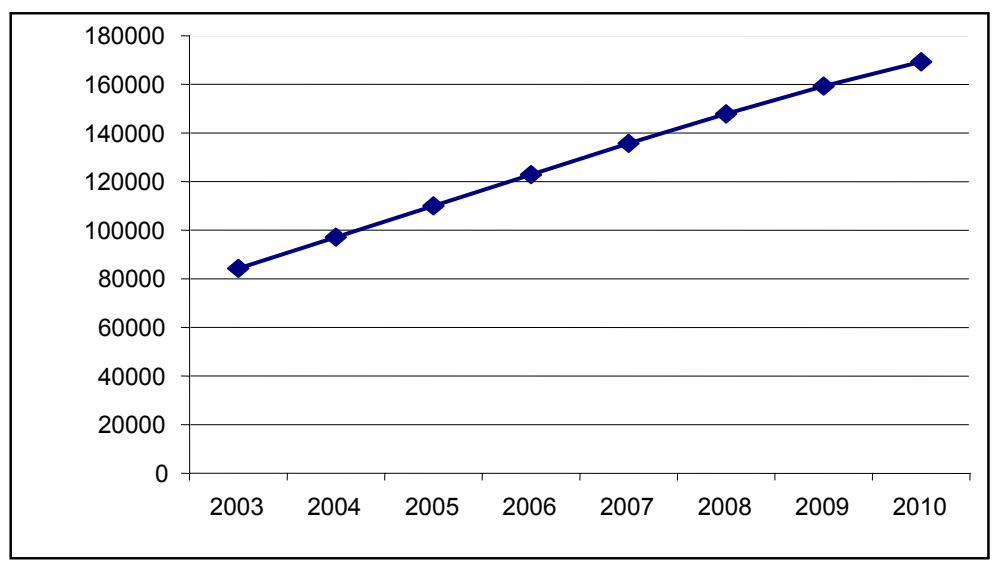

The graph below refers to children aged 0-17 years, whose mothers died of AIDS and from other causes. A comparison of the orphans whose mothers died of AIDS with orphans whose mothers died from other causes shows a very large difference. We note that the number of maternal orphans due to AIDS is tending to increase, while the number of orphans whose mothers die for other reasons is tending to decline slightly. It is forecast that the number of maternal orphans due to AIDS will increase from about 227,834 in 2004, to about 272,051 in 2005.

Over time, the proportion of these AIDS orphans will tend to rise. In 2010, if there is no effective intervention, it is expected that more than 500,000 maternal orphans (about $48 \%$ of all maternal orphans), will result from AIDS. It is important to stress that the fact that the mothers died of AIDS does not mean that all the orphans carry the HIV virus. In reality most of these orphans are HIV negative, either because they were born before their mothers were infected, or because vertical transmission did not occur.

\section{Graph 9: Maternal Orphans \\ (0-17 years), 1999-2010}

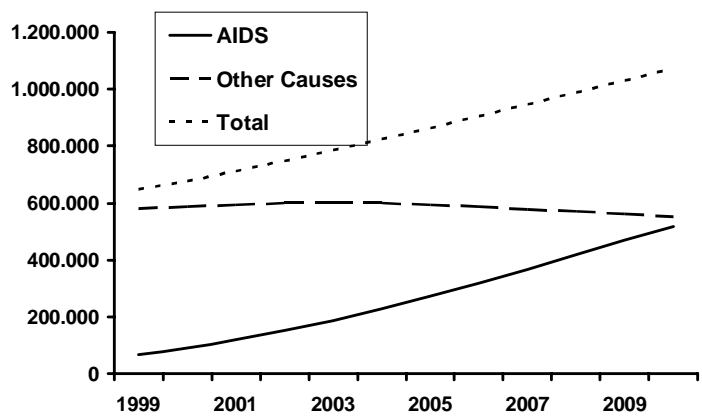


A further consequence of AIDS is the reduced life expectancy or longevity of the population, as can be noted from the graph below. In a scenario without AIDS, it has been estimated that life expectancy at birth would rise from approximately 44 years in 1999 to about 50 years in 2010. But considering the effects of the epidemic, the longevity of Mozambicans could be lower in future. For the year 2010 , it is forecast that this deficit may rise to over 14 years, if there are no effective interventions.

\section{Graph : Life expectancy 1999-2010}

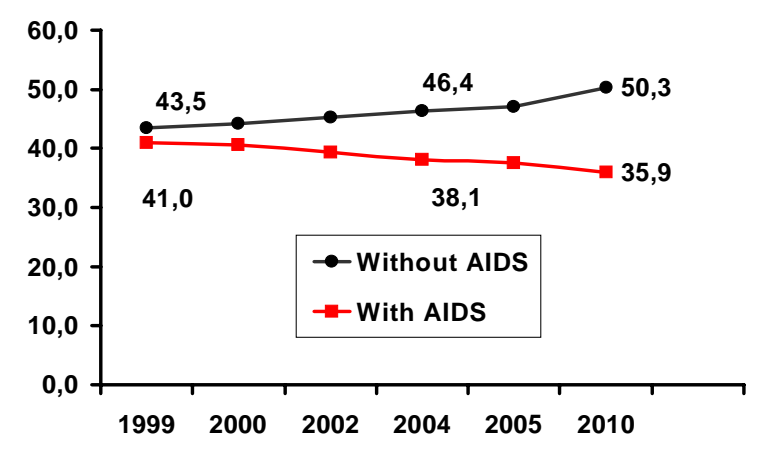

This study presents relevant data for designing action in the struggle against HIV-AIDS. Analysis of the data from the 2002 round strengthens the hypothesis that the Central region has reached the mature phase of the epidemic's evolution, with the exception of Zambézia, where the epidemic is growing. The Southern region, with the epidemic slowly on the rise, is in the intermediate phase of the epidemic's evolution. In the Northern region, the epidemic seems to be still in a phase of growth. Young people, particularly girls, are the most vulnerable group. The mortality caused by AIDS is changing the population structure due to a sudden decrease in the number of adults over 30 years old. This will have negative effects on the country's socio-economic fabric.

For 2005, in the struggle against the spread of HIVIAIDS, the government's actions will concentrate on:

- Increasing access to testing and counseling services;

- Reducing HIV transmission from mother to child, through supplying antiretroviral drugs;

- Increasing the capacity of the health units to diagnose and treat opportunist diseases; 
- Anti-retroviral treatment in selected health units, expecting to cover 20,800 people;

- Provision of home care to patients with HIVIAIDS;

- $58 \%$ of funds channelled by the CNCS-SE to OSC's (Civil Society Organisations), and public and private sector institutions to strengthen their capacities;

- $20 \%$ of community initiatives supported by CNCS-SE in supporting the country's orphans and vulnerable children;

- Ensuring improved coordination of interventions by all partners involved in the fight against HIVIAIDS, in the light of PEN II and of the Operational Plan in the framework of the national response;

- Divulge the Strategic Plan for the Fight against HIVIAIDS - PEN 2005/2009 (PEN II) and its respective Operational Plan;

- Ensure that all sectors draw up operational plans that contribute to meeting the objectives and targets of PEN II;

- Encourage the various sectors to promote harmonisation of their respective development plans and programmes with the national strategy to fight against HIVIAIDS;

- Negotiate simplification of disbursement mechanisms and administrative procedures for the funds made available for the fight against HIVIAIDS;

- Propose the establishment of levels of authority by administrative division for the approval of projects against HIVIAIDS;

- Ensure greater involvement of local communities and their leaderships in actions fighting against HIVIAIDS; and

- Strengthen the income generating capacity, the food security and nutritional support of individuals, families and communities affected by HIVIAIDS.

In 2005 , it is expected that the HIV prevalence among adults will reach $15.6 \%$.

\section{Macro-economic impact of HIV-AIDS}

The literature on HIVIAIDS and economic growth is far from drawing definitive conclusions as to the magnitude of the impact and the relative importance of various channels through which this impact may occur. Nonetheless, some essential indications arise from the analyses made so far. Among them, the long duration of this pandemic is crucial. For example, the official projections of the demographic impact of HIVIAIDS on Mozambique assume an interval of 9 years between infection and death. Given the long period separating infection and death, the projections for deaths from AIDS up to 2013 are already essentially 
programmed within the system. This happens because most of the people who, according to the estimates, will die in this decade, and at the start of the next decade, are currently infected with HIVIAIDS. Given that the pandemic is going to continue over a long period of time, small impacts on the determinants of growth (such as technical progress, physical capital and human capital) are going to accumulate, with substantial implications for the economy.

Recently, special attention has been paid to the accumulation of human capital. With AIDS it is expected that the population of school age will shrink, reducing that part of the school age population who actually attend school. This calls into question the capacity of the education system to carry out its duties. All these factors point to a reduction in the ratio of accumulation of human capital. If, as is believed, educated people tend to be more productive and innovative, then lower rates of accumulation of human capital, due to an educational system that has deteriorated, will reduce the economic growth rate, possibly during a considerable period of time.

Analyses of the implications of HIVIAIDS for growth, using a computational model of general equilibrium for Mozambique undertaken in 2001-2002, show that AIDS cases and deaths may have a great impact on economic growth. The analyses show that annual GDP growth rates per capita would be between $0.3 \%$ and $1.0 \%$ lower than in a fictitious scenario without AIDS, during the period from 1997 to 2010, with strongest effects in the period 2005 - 2010. The largest causes of reduction in growth are: (1) slower productivity growth rate, (2) slower rate of population growth and of accumulation of human capital, and (3) reduced ratio of accumulation of physical capital. Each of these three effects is important.

Given that the HIV-AIDS pandemic will probably last for a prolonged period of time, the impacts mentioned will go on accumulating, resulting in major long term impacts on the economy. Consequently, successful initiatives in preventing faster spread of HIV infection, and in fighting economic upheavals due to deaths from AIDS, while maintaining at the same time the basic conditions for growth, will probably earn large returns.

Maintaining the basic conditions for growth is also important. PARPA envisages growth in GDP of about eight per cent, and in per capita GDP of five per cent per year - growth rates that were achieved in the previous decade. As for economic growth per capita, the projected impacts of AIDS on economic growth represent a fraction of the target. For the period 2005-2010, this fraction should be within the interval of between 10 and 50 per cent of the target growth rate per capita of five per cent. Thus, mitigating the pandemic and maintaining the basic conditions for economic growth are both important for continued economic growth and poverty reduction, although the second element (the maintenance of the basic conditions for economic growth) is probably more important. 


\section{MACROECONOMIC NATIONAL CONTEXT}

The results observed over the past year during the implementation of the 2004 PES indicate that the targets laid down are being reached. The preliminary data indicate:

- A growth in Gross Domestic Product of $7.2 \%$.

- An accumulated inflation rate of $9.3 \%$.

- A growth in commodity exports, excluding those from mega-projects, of about $11 \%$.

For 2005, the government's economic and social policy, following and making operational the strategy for the struggle against absolute poverty, expressed in the Action Plan for the Reduction of Absolute Poverty (PARPA), will continue to be marked by a series of actions contributing to sustainable economic growth and to reducing absolute poverty and social inequalities. Thus the main objectives to be achieved are set as follows:

- A growth in Gross Domestic Product of between 7 and $8 \%$.

- Holding the annual inflation rate in the range of 7 to $8 \%$.

- A growth in commodity exports, excluding those from mega-projects, of about $6 \%$ and, including the mega-projects, $46.5 \%$.

\section{TOTAL SUPPLY AND DEMAND - GROWTH RATES IN VOLUME (\%)}

\begin{tabular}{|lrrrr|}
\hline & 2002 & 2003 & 2004 & 2005 \\
\hline TOTAL SUPPLY & 16.6 & 11.5 & 5.6 & 13.2 \\
TOTAL GROSS DOMESTIC PRODUCT & 7.4 & 8.1 & 7.2 & 7.7 \\
IMPORTS & 50.1 & 20.4 & 1.8 & 26.5 \\
& & & & \\
TOTAL DEMAND & 16.6 & 11.5 & 5.6 & 13.2 \\
CONSUMPTION & 7.7 & $\mathbf{1 6 . 1}$ & 3.5 & 14.9 \\
$\quad$ Private Consumption (by difference) & 10.6 & 18.0 & 3.3 & 15.5 \\
$\quad$ Government Consumption & -12.0 & 0.1 & 5.4 & 9.1 \\
& & & & \\
GROSS CAPITAL FORMATION & 52.4 & -11.1 & -9.9 & 20.4 \\
EXPORTS & 7.7 & $\mathbf{3 4 . 8}$ & $\mathbf{3 3 . 3}$ & 1.9 \\
\hline GDP AT CURRENT PRICES 10^6 Meticais & $\mathbf{8 5 , 2 0 6 , 7 8 9}$ & $\mathbf{1 0 2 , 7 5 3 , 2 0 0}$ & $\mathbf{1 2 4 , 0 9 2 , 7 8 4}$ & $\mathbf{1 4 4 , 2 0 6 , 5 8 7}$ \\
\hline
\end{tabular}

\section{IV.1. OVERALL AND SECTOR PRODUCTION}

Overall and sector production for 2005 indicates a growth rate of $5.7 \%$. To attain this result, the expected performance in agriculture, mineral resources, 
manufacturing industry and transport and communications will be determinant. Excluding aluminium, production will grow at a rate of $6.3 \%$. In fact, phase II of Mozal reached its maximum productive capacity in 2004 ; for 2005 , an aluminium production of almost the same levels as 2004 is forecast.

\section{OVERALL AND SECTOR PRODUCTION - Growth Rates in Volume (\%)}

\begin{tabular}{|llll|}
\hline PRODUCTION & $\mathbf{2 0 0 3}$ & $\mathbf{2 0 0 4}$ & $\mathbf{2 0 0 5}$ \\
\hline AGRICULTURE, LIVESTOCK AND FORESTRY & 8.6 & 9.1 & 6.6 \\
$\quad$ Agriculture & 9.8 & 9.0 & 7.2 \\
Livestock & 17.4 & 12.8 & 5.1 \\
Forestry & -8.7 & 5.6 & 3.1 \\
FISHERIES & 11.1 & -3.8 & 7.7 \\
MINING INDUSTRY & 31.6 & 215.7 & 41.6 \\
MANUFACTURING INDUSTRY & 14.9 & 12.7 & 3.1 \\
ELECTRICITY AND WATER & -12.6 & 5.7 & 14.8 \\
CONSTRUCTION & -7.6 & -14.6 & 0.2 \\
TRADE & 5.3 & -0.1 & 6.5 \\
REPAIR SERVICES & 2.1 & 0.1 & 0.2 \\
RESTAURANTS AND HOTELS & 8.6 & 1.1 & 0.7 \\
TRANSPORT AND COMMUNICATIONS & 8.6 & 16.4 & 13.1 \\
FINANCIAL SERVICES & 0.8 & 0.9 & 1.0 \\
RENT OF BUILDINGS & 2.4 & 2.5 & 2.5 \\
SERVICES TO COMPANIES & 2.0 & 1.9 & 3.1 \\
GOVERNMENT SERVICES & 6.1 & 5.6 & 9.3 \\
OTHER SERVICES & 9.7 & 8.5 & 0.8 \\
\hline TOTAL PRODUCTION & $\mathbf{4 . 8}$ & $\mathbf{4 . 6}$ & $\mathbf{5 . 7}$ \\
\hline TOTAL PRODUCTIONS WITHOUT ALUMINIUM & $\mathbf{2 . 3}$ & $\mathbf{2 . 2}$ & $\mathbf{6 . 3}$ \\
\hline TOTAL PRODUCTION - NO GAS OR ALUMINIUM & $\mathbf{2 . 4}$ & $\mathbf{1 . 3}$ & $\mathbf{5 . 5}$ \\
\hline TOTAL PRODUCTION WITHOUT MEGA-PROJECTS & $\mathbf{7 . 4}$ & $\mathbf{5 . 1}$ & $\mathbf{7 . 3}$ \\
\hline
\end{tabular}

Without mega-projects, production will grow at a rate of $7.3 \%$. As may be concluded, the presence of mega-projects, under construction and operating, conditions and distorts the normal behaviour of the overall production of the economy which has evolved at the rate of about $7.0 \%$. The joint increase to be noted in agriculture, manufacturing industry and transport and communications is equivalent to about $60 \%$ of the programmed increase.

All the other sectors will present a positive evolution. Worthy of note are the increases forecast in the sectors of Mineral Resources (41.6\%) and Electricity and Water $(14.8 \%)$. The performance of the mining sector is based on the increases in the production of the Pande-Temane gas; while increased energy production results from the normal functioning of Hidroeléctrica de Cahora Bassa, after the end of rehabilitation, modernisation and automation work that 
began in 2003, and the expansion of the national electricity grid to the northern region and other parts of the country.

The construction sector will record a reversal of its performance indicators of recent years, associated with the end to construction of major undertakings that are now operational.

\section{A. AGRICULTURE, LIVESTOCK AND FORESTRY}

As in the 2003/04 campaign, no dramatic climatic disturbances are forecast for the 2004/2005 agricultural campaign, and policy for the sector will remain oriented towards the reduction of absolute poverty and towards guaranteeing the food security of rural households, To this end, the family sector, given its importance in reducing levels of absolute poverty will continue to merit special attention in order to raise levels of production and productivity.

The effort in this sector will be centred on promoting the sustainable use of resources, with community participation, livestock assistance, the encouragement of basic food and cash crops, making available sustainable production and post-harvest technologies, and simplification of the procedure for obtaining DUAT (Land Use Titles), with greater stress on the small producers.

\section{AGRICULTURAL PRODUCTION (Growth Rates in Volume \%)}

\begin{tabular}{|l|rrr|}
\hline TOTAL & $\mathbf{2 0 0 3}$ & $\mathbf{2 0 0 4}$ & $\mathbf{2 0 0 5}$ \\
COMMERCIAL & $\mathbf{9 . 8}$ & $\mathbf{9 . 0}$ & $\mathbf{7 . 2}$ \\
FAMILY SECTOR TOTAL & 109.3 & 10.5 & 12.0 \\
FAMILY SECTOR MARKETED & 3.4 & 8.8 & 6.6 \\
AUTOCONSUMPTION & 4.3 & 12.1 & 8.3 \\
\hline
\end{tabular}

A growth in agricultural production is thus expected of about $7.2 \%$ overall. The commercial sector will record an increase of $12.0 \%$ resulting from the significant increase in production expected in some food crops and products for industry, notably tobacco, given the weight they have in the structure of commercial marketing. The dynamic of this sector is linked to the restructuring and rehabilitation of some productive units, particularly for sugar cane, cotton, tobacco and maize. 


$\begin{aligned} & \text { COMMERCIAL PRODUCTION AND FAMILY SECTOR MARKETING } \\
& \text { (Growth Rates in Volume \%) }\end{aligned}$
\begin{tabular}{|llll|}
\hline ITEM & $\mathbf{2 0 0 3}$ & $\mathbf{2 0 0 4}$ & $\mathbf{2 0 0 5}$ \\
\hline EXPORT PRODUCTS & $\mathbf{- 4 . 4}$ & $\mathbf{1 0 . 5}$ & $\mathbf{1 6 . 6}$ \\
Cashew nuts & 27.2 & -32.6 & 62.8 \\
Cotton & -34.8 & 69.9 & 0.0 \\
Copra & 14.7 & -3.1 & 0.0 \\
Sugar cane & 21.9 & -3.3 & 21.9 \\
Citrus & 5.0 & 1.6 & 0.0 \\
Leaf tea & 0.9 & 19.2 & 5.8 \\
\hline BASIC FOOD CROPS & $\mathbf{1 3 . 6}$ & $\mathbf{6 . 0}$ & $\mathbf{5 . 3}$ \\
Maize & 7.9 & 16.1 & 5.9 \\
Unhusked rice & 8.5 & -5.5 & 7.0 \\
Sorghum & -0.4 & 5.1 & 6.4 \\
Cassava & 4.2 & 4.6 & 5.2 \\
Shelled groundnuts & 0.1 & 19.6 & 7.0 \\
Beans & 1.7 & 7.1 & 7.7 \\
Vegetables & 60.5 & 10.5 & 0.0 \\
Onions & 105.6 & -22.3 & 9.3 \\
\hline PRODUCTS FOR INDUSTRY & $\mathbf{8 0 . 5}$ & $\mathbf{2 8 . 4}$ & $\mathbf{1 5 . 6}$ \\
Tobacco & 73.2 & 68.3 & 22.9 \\
\hline Tomato & 86.5 & 0.0 & 6.8 \\
\hline TOTAL & $\mathbf{2 0 . 5}$ & $\mathbf{1 1 . 7}$ & $\mathbf{9 . 3}$ \\
\hline
\end{tabular}

For the group of export products, growth of $16.6 \%$ is forecast. Thus a growth rate higher than that recorded in $2004(10.5 \%)$ is expected.

Cashew production will grow by $62.8 \%$. To promote production of this crop, there will be continued training of producers, and development of activities to handle pests and disease, in Cabo Delgado, Nampula, Zambézia, Inhambane, Gaza and Maputo provinces.

For the group of basic food crops, growth of approximately $5.3 \%$ is forecast. In general, increases are expected in all food crops, namely grains, root crops and legumes, due to increases in the area under cultivation and in productivity. In recent years, there has been a growth rate in food crops relatively higher than the rate of expansion of the area under cultivation, which reflects improvements in productive technical efficiency, and the success of the agricultural services provided to the rural population.

The production and marketing levels of maize $(5.9 \%)$ and cassava $(5.2 \%)$ are worth stressing. These are the products with most weight in food crops taken as 
a whole, and are thus fundamental in guaranteeing food security and reducing absolute poverty.

For the group of products for industry, growth of $15.6 \%$ is forecast. Determinant in this is the growth recorded in tobacco production and marketing $(22.9 \%)$.

Dynamism in family sector marketing is expected. There are prospects for increases in all crop groups - namely export crops (18.8\%), food crops $(6.0 \%)$ and products for industry $(12.8 \%)$.

\section{FAMILY SECTOR MARKETING}

(Growth Rates in Volume \%)

\begin{tabular}{|llll|}
\hline ITEM & $\mathbf{2 0 0 3}$ & $\mathbf{2 0 0 4}$ & $\mathbf{2 0 0 5}$ \\
\hline EXPORT PRODUCTS & $\mathbf{- 4 . 7}$ & $\mathbf{1 7 . 3}$ & $\mathbf{1 8 . 8}$ \\
Cashew nuts & 27.2 & -32.6 & 62.8 \\
Cotton & -27.1 & 79.1 & 0.0 \\
Copra & 1.4 & 3.7 & 3.0 \\
Sugar cane & 0.0 & 0.0 & 0.0 \\
Citrus \\
Leaf tea
\end{tabular}

\begin{tabular}{|llll|}
\hline BASIC FOOD CROPS & $\mathbf{5 . 4}$ & $\mathbf{7 . 8}$ & $\mathbf{6 . 0}$ \\
Maize & 1.0 & 15.0 & 6.6 \\
Unhusked rice & 19.0 & -6.5 & 7.5 \\
Sorghum & 0.3 & 5.1 & 6.0 \\
Cassava & 3.8 & 4.3 & 5.3 \\
Shelled groundnuts & 0.0 & 20.0 & 6.8 \\
Beans & 1.7 & 7.2 & 7.8 \\
Vegetables & 7.4 & 13.9 & 0.0 \\
Onion & 55.6 & 6.5 & 9.6 \\
\hline PRODUCTS FOR INDUSTRY & $\mathbf{8 . 7}$ & $\mathbf{3 3 . 1}$ & $\mathbf{1 2 . 8}$ \\
Tobacco & 40.9 & 46.9 & 13.2 \\
Tomato & -29.7 & 0.0 & 11.4 \\
\hline TOTAL & $\mathbf{4 . 3}$ & $\mathbf{1 2 . 1}$ & $\mathbf{8 . 3}$ \\
\hline
\end{tabular}

Despite the high figures programmed for auto-consumption (5.5\%), in recent years there have been improvements in family sector marketing, and an increase of $8.3 \%$ is forecast for 2005 .

In the livestock sector, an overall growth rate of $5.1 \%$ is forecast. 


\section{LIVESTOCK PRODUCTION (Growth Rates in Volume (\%)}

\begin{tabular}{|lllll|}
\hline ITEM & \multicolumn{2}{c}{ 2004 } & \multicolumn{2}{c|}{ 2005 } \\
& COMM. & FAM. & COMM. & FAM. \\
\hline Cattle & 13.6 & 11.3 & 8.0 & 8.0 \\
Pigs & 0.0 & 4.9 & 4.9 & 4.9 \\
Live birds & 19.0 & 12.8 & 4.2 & 4.2 \\
Fresh eggs & 41.6 & 35.9 & 4.5 & 4.0 \\
\hline TOTAL & $\mathbf{1 8 . 3}$ & $\mathbf{1 2 . 5}$ & $\mathbf{5 . 1}$ & $\mathbf{5 . 0}$ \\
\hline
\end{tabular}

Key: $\mathrm{COMM}=$ Commercial sector; $\mathrm{FAM}=$ Family sector

Domestic contribution to the overall supply of beef has been growing in recent years. In fact, while only $26 \%$ of beef consumption came from national cattle production in 2000, the figure rose to $58 \%$ in 2001 and to $67 \%$ in 2002. Apart from the livestock breeding programme, this change results: from a relaxation of the containment policy, thanks to the stabilisation of the herd, the ban on the entry into Mozambique of cattle from neighbouring countries due to health problems, and to the environment of stability which has made it possible to step up marketing.

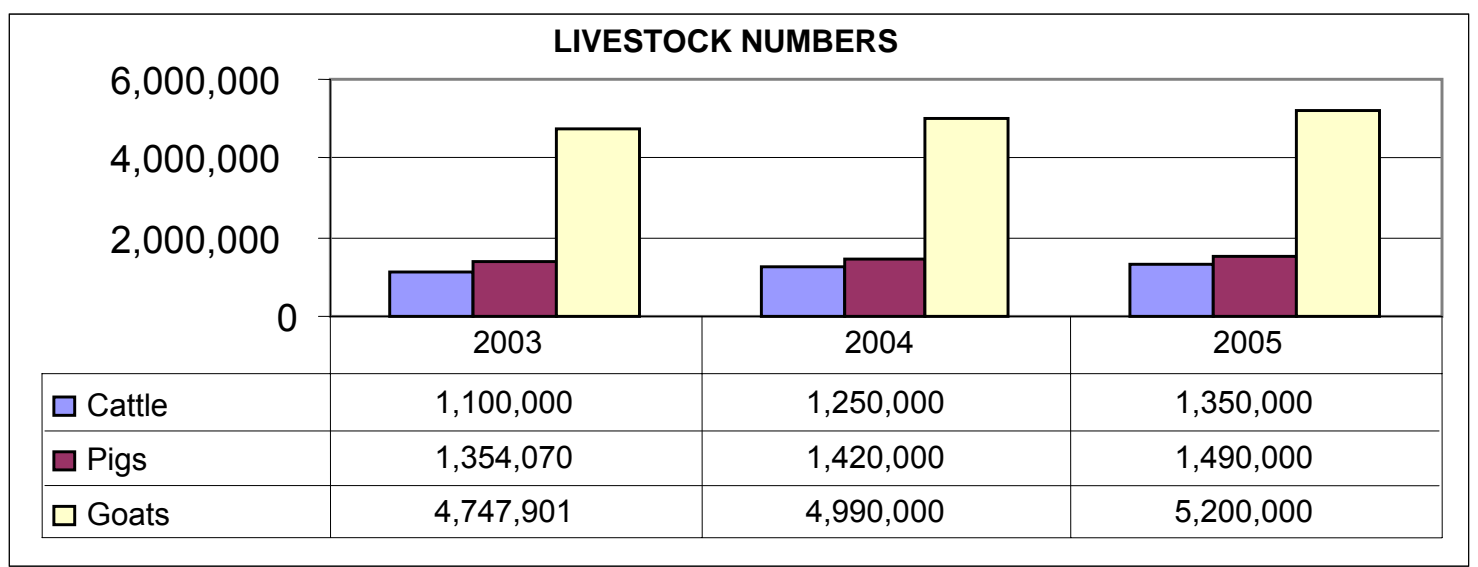

According to recent Agricultural Survey data (TIA 2003), in the coming years the country might reach the effective peak of about 1.5 million head of cattle recorded in the 1980s.

Forestry production will grow by $3.1 \%$ in 2005 . To secure sustainable exploitation of forestry resources, the Development Policy and Strategy for the forestry sector and the Forestry Regulations have promoted exploitation in the form of forestry concessions, thus reducing disorderly exploitation. 


\section{B. FISHERIES}

Improvements in the system for gathering statistical data on artisanal fishing, with the adoption of the sampling method, allows us today to present a more realistic picture of the contribution made by this sub-sector to fisheries production. The production of artisanal fishing, commercial fishing and fish farming, taken as an aggregate, is forecast to rise in 2005 by $7.7 \%$. This results essentially from the rapid growth in fish farming, and the significant contribution of artisanal fishing.

FISHERIES PRODUCTION (Growth Rates in Volume \%)
\begin{tabular}{|llll|}
\hline TOTAL & $\mathbf{2 0 0 3}$ & $\mathbf{2 0 0 4}$ & $\mathbf{2 0 0 5}$ \\
\hline COMMERCIAL & $\mathbf{1 1 . 1}$ & $\mathbf{- 3 . 8}$ & $\mathbf{7 . 7}$ \\
FAMILY SECTOR TOTAL & -9.2 & -3.2 & 7.4 \\
FAMILY SECTOR MARKETED & 41.6 & -4.4 & 7.9 \\
AUTO-CONSUMPTION & 53.8 & -5.5 & 8.0 \\
\hline
\end{tabular}

ARTISANAL FISHING - Growth Rates in Volume (\%)
\begin{tabular}{|lllr|}
\hline ITEM & $\mathbf{2 0 0 3}$ & $\mathbf{2 0 0 4}$ & $\mathbf{2 0 0 5}$ \\
\hline
\end{tabular}
\begin{tabular}{|llll|}
\hline Lobster & 10.0 & 0.0 & 0.0 \\
Crab & -55.6 & -57.9 & 0.0 \\
Deep water prawns & 0.0 & 0.0 & 0.0 \\
Fresh and frozen fish & 66.7 & -4.3 & 8.5 \\
Kapenta & 0.0 & 0.0 & 0.0 \\
By-catch & 0.0 & 0.0 & 0.0 \\
Prawns * & -8.3 & -26.3 & 16.3 \\
Crayfish & 0.0 & 0.0 & 0.0 \\
Squid and octopus & -38.4 & -40.9 & -13.0 \\
\hline
\end{tabular}




COMMERCIAL FISHING - Growth Rates in Volume (\%)
\begin{tabular}{|llll|}
\hline IITEM & $\mathbf{2 0 0 3}$ & $\mathbf{2 0 0 4}$ & $\mathbf{2 0 0 5}$ \\
\hline & 7.7 & 100.0 & 150.0 \\
\hline Lobster & -50.4 & 175.0 & -43.2 \\
Crab & -9.7 & -28.2 & 2.8 \\
Deep water prawns & 68.0 & -53.1 & 112.3 \\
Fresh and frozen fish & 16.2 & 67.6 & -0.1 \\
Kapenta & 0.6 & -8.5 & -2.6 \\
By-catch & -17.5 & 9.3 & -0.4 \\
Prawns * & 37.5 & 20.0 & 13.6 \\
Crayfish & -25.0 & 73.5 & -22.7 \\
Squid and octopus & & & \\
\hline
\end{tabular}

* Includes fish farming

Commercial prawn production will record a slight decline $(-0.4 \%)$, despite growth in the production of farmed prawns, resulting from the expansion of production areas in Zambézia, Sofala and Cabo Delgado. The traditional prawn catch is forecast to reach 8,000 tonnes, against 8,085 tonnes in 2004. In general, the fisheries produce export plan is about 15,730 tonnes, against 20,504 in 2004 . It should be noted that there will be continued increase in exports from fish farming, with the start of the commercial catch and export of live farmed prawns, to be used as reproducers for fish farming production.

\section{EXTRACTIVE INDUSTRY}

Production from extractive industry has been showing significant levels of growth, with the alteration of the production structure with new products gaining in weight. The plan for 2005 forecasts a growth rate of $41.6 \%$. This growth is based on the increases forecast in the production of natural gas at Pande-Temane, and limestone, riolites and tantalite, in Maputo, Inhambane and Zambézia provinces. In the current productive structure, these products represent about $80 \%$ of national mining production. Gas is the mining product that creates the greatest production value in this sector.

In the search for sustainable exploitation of natural gas, additional reserves of gas have been located in areas adjacent to the Temane field. Conclusion of evaluating the reserves is expected this year.

Tantalite production has increased with the opening of the new mine at Naquissupa, and with the re-activation of old mines. The reactivation of the Muiane mine is expected in 2005. 
Extension of the national electricity grid to Ancuabe, forecast for late 2005, opens good prospects for reactivating graphite production.

\begin{tabular}{|c|c|c|c|}
\hline \multicolumn{4}{|c|}{ MINERAL RESOURCES - Growth Rates in Volume (\%) } \\
\hline ITEM & 2003 & 2004 & 2005 \\
\hline Coal & -15.6 & -55.0 & 58.6 \\
\hline Bauxite & 29.3 & -23.9 & 17.0 \\
\hline Graphite & 0.0 & 0.0 & 0.0 \\
\hline Unworked bentonite & 0.0 & 0.0 & 21.8 \\
\hline Worked bentonite & 18.0 & -15.5 & 8.1 \\
\hline Sieved bentonite & 57.9 & -32.5 & 35.3 \\
\hline Activated bentonite & 0.0 & 0.0 & 0.0 \\
\hline Marble sheets & 2.5 & 33.6 & 12.2 \\
\hline Marble blocks & -0.2 & 36.5 & 10.2 \\
\hline Garnets & -61.3 & 511.0 & 76.9 \\
\hline Lapidated stones & 0.0 & 0.0 & 0.0 \\
\hline Gold & 271.6 & -10.8 & 16.1 \\
\hline Aquamarines & -69.4 & 132.1 & 3.9 \\
\hline Tourmalines & 370.4 & 170.2 & 1.0 \\
\hline Tantalite & 302.3 & 277.4 & 4.6 \\
\hline Beryl & 44.2 & -65.1 & 112.5 \\
\hline Sand & 72.4 & 4.2 & 14.4 \\
\hline Limestone & 3.6 & 18.2 & 5.4 \\
\hline Riolites & -9.6 & 5.8 & 3.6 \\
\hline Granite & -19.5 & -3.4 & 4.6 \\
\hline Dumortiorite & 0.0 & 182.5 & 10.6 \\
\hline Natural gas & 4.1 & 91405.1 & 91.0 \\
\hline \begin{tabular}{|l} 
TOTAL \\
TOT
\end{tabular} & 31.6 & 215.7 & 41.6 \\
\hline
\end{tabular}

Coal production is expected to continue recording strong signs of recovery $(58.6 \%)$ once the problems concerned with the productive process at the Chipanga XI mine are solved, stimulated by the rise in coal prices, with increased demand on the world market.

The levels of production of marble in sheets and blocks have been unstable due to several factors, notably the existence on the market of alternative products, such as tiles and granite imported from South Africa. Increases in production are expected in 2005 , with the installation of new equipment in the quarries, and with a reliable energy supply to the quarries, thanks to the expansion of the national electricity grid to the north of the country.

Garnet production will record growth of $76.9 \%$ in 2005. Privatisation of the company SOMEC, E.E., which holds the exploitation rights over this mining area, is under way. 
The production of granite, bauxite, bentonite and dumortiorite has faced problems in finding markets. These products are conditional on orders and supply contracts previously signed with clients. In 2005 efforts will be pursued to rehabilitate the bentonite mine at Boane which was destroyed by the 2000 floods.

Small scale mining production (gold, tourmalines, aquamarines and quartz) has recorded positive results in the last 3 years, and positive levels of growth are also expected in 2005. The main supports for the results in gold production are the performance of licensed operators in Nampula, Zambézia, Manica and Niassa, government support for artisanal operators, and rehabilitation of access routes to the gold production areas in Niassa.

\section{MANUFACTURING INDUSTRY}

In 2005 industry will continue to be one of the determinant factors for economic development. Growth in commercial industrial production of $3.1 \%$ is forecast. Mozal will continue producing at its full installed capacity, and its production is forecast as stationary (0.5\%) in comparison with 2004.

\begin{tabular}{|l} 
MANUFACTURING INDUSTRY - Growth Rates in Volume (\%) \\
\begin{tabular}{|lrrr|}
\hline BUSINESS SECTOR & & & \\
\hline Item & $\mathbf{2 0 0 3}$ & $\mathbf{2 0 0 4}$ & $\mathbf{2 0 0 5}$ \\
\hline Food processing & 3.9 & 9.8 & 4.4 \\
Drinks and tobacco & 12.7 & 3.7 & 4.6 \\
Textiles and clothing & -7.6 & 10.9 & 12.0 \\
Leather and leather articles & 33.6 & -4.7 & 0.3 \\
Wood industry & 17.9 & -51.4 & 0.0 \\
Paper and printing & -9.5 & 45.5 & 1.3 \\
Chemical products & 14.2 & -5.3 & 0.9 \\
Non-metallic minerals & 21.4 & 3.4 & 0.0 \\
Basic engineering & 51.1 & 33.7 & 0.5 \\
Aluminium & 51.6 & 33.8 & 0.5 \\
Steel & 0.0 & 0.0 & 0.0 \\
Others & -40.5 & 2.1 & 1.2 \\
Metallic prod.,machines and equip. & 53.3 & 5.0 & 4.0 \\
Furniture and other manufactured goods & 161.5 & 13.7 & 2.8 \\
\hline TOTAL & $\mathbf{2 3 . 7}$ & $\mathbf{1 7 . 4}$ & $\mathbf{3 . 2}$ \\
\hline
\end{tabular}
\end{tabular}

The food, drink and tobacco industries are the major pivot for growth in the country's manufacturing industry because, on the one hand, of the dynamism they have shown in recent years, and on the other, because of the weight they have in the overall structure of industrial production. 
Improvement in the performance of the drinks industry is expected, with the rehabilitation and installation of new equipment in the company Cervejas de Moçambique (Beers of Mozambique).

The timber and furniture industries, after strong signs of recovery in 2003, with the increase in demand for school furniture, are forecast to show stationary behaviour in 2005, because the main productive unit (NOVARTE) is facing financial problems.

The behaviour of the paper and printing industries has been unstable over the last 3 years. After presenting a sharp rate of growth in 2002, in 2003 they recorded declines in production. The substantial performance registered in 2004 does not allow prospects for high rates of growth, although some sign of recovery in this area is envisaged. Thus a slight growth rate (1.3\%) is forecast in 2005.

The chemical, rubber and plastics industry has shown oscillations in its production levels, due to the presence on the market of similar products imported at low cost, with greatest impact on the manufacture of chemical products and plastic materials.

In the area of basic engineering, a growth of only $0.5 \%$ is forecast, explained by an increase in aluminium production from the 547,606 tonnes produced in 2004, to 550,344 tonnes. Excluding aluminium, this sector will grow by $2.3 \%$, despite the entry of two new companies, Memoz and Ferpinta Moçambique. The first is dedicated to metallurgical services, and the second to producing zinc sheeting.

Some constraints remain in the industrial sector, concerning the poor quality of the electricity supplied, the high costs of production caused by the excessive cost of electricity, water, customs charges, obsolete technologies and limited access to bank credit, which result in low levels of production and competitiveness of some industrial units.

An improvement in the quality of the electricity supplied to industries in northern Mozambique is expected in 2005, thanks to the expansion of the national electricity grid in this part of the country. On the other hand, it is expected that implementation of Ministerial Diploma No 99/2003, of 13 August, that approves the Customs Regulations for manufacturing industry, will stimulate the areas covered, through reducing customs charges on imported raw materials.

\section{E. ELECTRICITY AND WATER}

The energy and water sector is forecast to grow by $14.8 \%$. This performance is based on the conclusion of the modernisation and automation work at Hidroeléctrica de Cahora Bassa, which will allow the normal operation of the 
generators, and hence increased production of electricity for export both in a regime of firm energy and one of peak power.

In 2005, the expansion of the electricity grids to 20 district capitals and the installation of solar-powered systems in 10 localities are envisaged. Water production will continue to accompany the additional needs created by rural and urban population growth, which allows a forecast of a slight growth of $2.5 \%$.

\section{F. CONSTRUCTION}

In the area of construction and assembly, a reversal in the trend of the production indicators recorded in recent years is expected, which will represent a return to the normal functioning of this sector, after the conclusion of building work on Phase II of Mozal and of the Pande-Temane gas pipeline. In 2005, continued promotion of the heavy sands projects of Moma, Chibuto and Moebase is forecast, with a view to attracting larger volumes of investment.

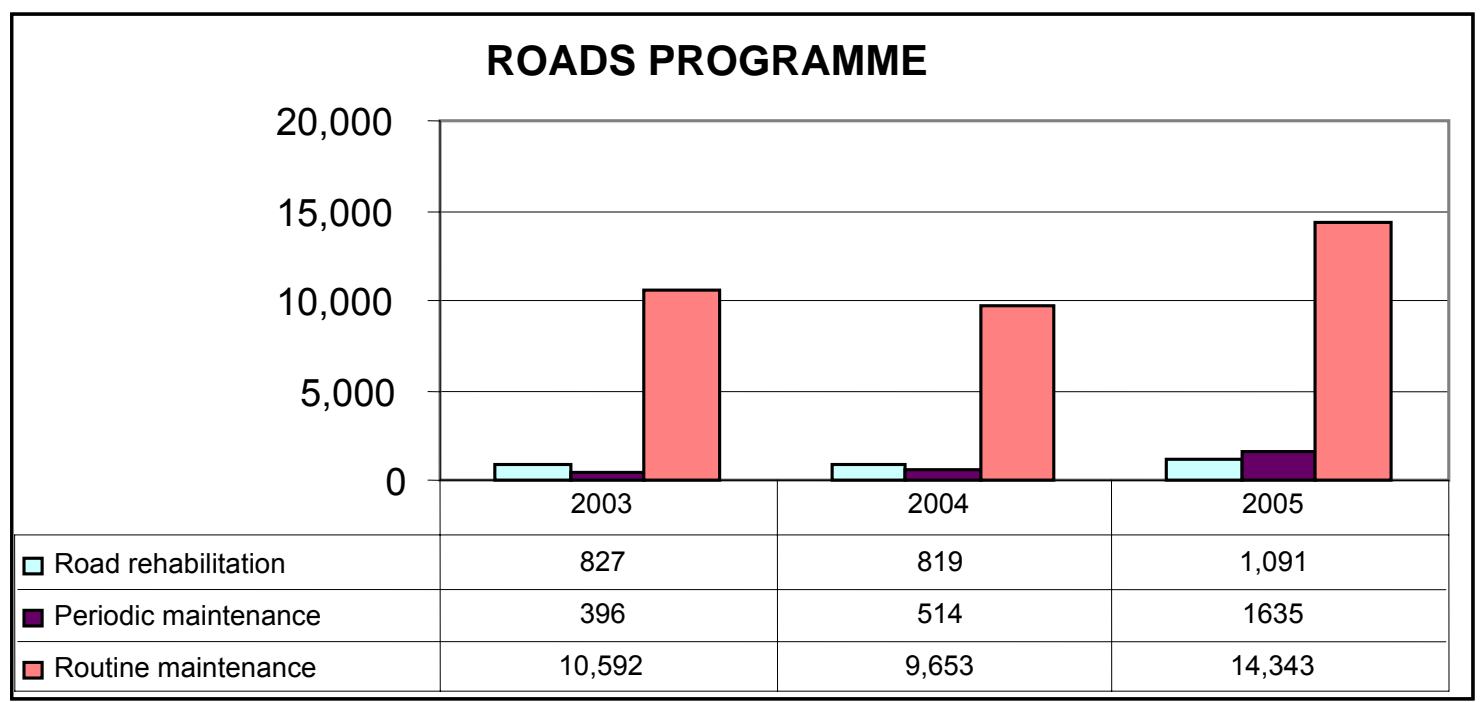

Excluding the mega-projects sub-sector, the construction sector will show a trend to growth compared with the levels of 2004. The work programmed in the roads area covers a total distance of 17,069 kms against 10,988 kms in 2004 .

\section{G. TRADE}

In the trade area, the Plan for 2005 forecasts a growth rate of $6.5 \%$. This growth is based on the envisaged growth in production of the real sector of the economy. Also forecast is an increase in commodity imports to feed the 
commercial flow of the economy. However, the accelerated increase forecast in the total volume of imports, as seen on the balance of payments, is due to demand from the mega-projects, and these provide no profit margin to domestic economic agents, since their imports go through no transactions internally.

\section{H. RESTAURANTS AND HOTELS}

The current pace of investments in the sector, and particularly the expansion in the number of beds and of hotels and similar establishments, is opening good prospects for the continuous growth of the sector. The entry into operation in 2003 of accommodation establishments classified with three, four and five stars, sustains the 2005 production plan. The performance envisaged is based on the forecast increase in tourism revenue in the balance of payments.

\section{TRANSPORT AND COMMUNICATIONS}

Production for 2005 indicates that the sector will reach an overall growth rate of $13.1 \%$. Road transport $(8.4 \%)$ and communications services $(37.7 \%)$ will contribute significantly.

TRANSPORT AND COMMUNICATIONS - Growth Rates in Volume (\%)
\begin{tabular}{|llll|}
\hline Item & $\mathbf{2 0 0 3}$ & $\mathbf{2 0 0 4}$ & $\mathbf{2 0 0 5}$ \\
\hline Rail transport & 68.8 & 13.6 & 16.6 \\
Road transport & -4.2 & 19.2 & 8.4 \\
Transport by pipeline & -13.1 & 3.5 & 15.5 \\
Maritime transport and coastal shipping & 171.7 & 61.4 & 9.8 \\
Air transport & 156.9 & 238.2 & -2.2 \\
Services related with Transport & 29.3 & -47.0 & 4.0 \\
Communications services & 2.8 & 15.7 & 37.7 \\
\hline TOTAL & $\mathbf{8 . 6}$ & $\mathbf{1 6 . 4}$ & $\mathbf{1 3 . 1}$ \\
\hline
\end{tabular}

The growth in road transport results from the increase recorded in public and semi-collective passenger transport, caused by the growth of the country's cities and towns, the encouragement of licensing of vehicles that have more than 25 seats, and the acquisition of new public buses.

Road freight transport has been conditioned by the needs imposed by the entire production and marketing of the real sector of the economy. In 2005, the volume 
of freight carried by roads will be relatively stagnant, compared with the amounts transported in 2004, associated with the freight transport recorded during the construction of the Pande gas pipeline.

The telecommunications performance is due to the expansion of the fixed and mobile telecommunications networks. Of particular note is the aggressive stance of the mobile and fixed phone operators as they try to expand their markets.

Although air traffic has been stimulated with the opening of new points of entry to the country, the implementation of the new civil aviation policy, the simplification of procedures for the licensing and entry of aircraft, and the increase in tourism, it will experience a decline in 2005 , reflecting the fact that this year no major international events are foreseen, like those that drove international passenger traffic in 2004.

\section{IV.2. MONETARY AND EXCHANGE SECTOR}

The monetary and exchange policy to be pursued in 2005 is guided by the final objectives of government economic policy, in terms of economic growth, the control of inflation, and equilibrium of the balance of payments.

In 2004 the monetary programme envisaged an annual growth in the Money Supply of $15 \%$, but by the end of December it had only grown by $6.1 \%$, influenced, essentially, by the appreciation of the metical against the US dollar. For 2005 an annual growth of $14.5 \%$ in the Money Supply is forecast, Gross International Reserves should cover between 5 and 6 months of imports of goods and services, and the programme makes space for a growth in Credit to the Economy in line with the nominal growth in GDP.

Interventions on the interbank monetary and exchange markets will be prioritized to regulate the behaviour of the monetary aggregates and thus guarantee the inflation objective.

In the area of strengthening the financial system, the following are envisaged:

- Concluding the timetable for the introduction of International Financial Reporting Standards (IFRS) in the institutions under its supervision;

- Finalising the study on the implications of the transition to IFRS on tax policy;

- Implementation of International Accounting Standards (IAS);

- Strengthening the institutional capacity of the Bank of Mozambique and of other regulatory authorities through issuing and implementing regulations 
on the Law of Credit Institutions and Financial Companies (LICSF) and the regulation on micro-finance;

- Implementation of the strategy of selling the state's shares in BIM.

\section{IV.3. INFLATION}

The accumulated rate of inflation, from January to December 2004, was $9.3 \%$ according to the Aggregate Price Index of the three main cities: Maputo, Beira and Nampula (MABENA). Breaking the figure down by cities, one notes that Nampula had slightly higher accumulated inflation with $11.9 \%$, while Maputo city reached $9.1 \%$ and Beira $8.5 \%$.

\begin{tabular}{|c|c|c|c|c|c|c|c|c|c|c|c|c|}
\hline & JAN & FEB & MAR & APR & MAY & JUN & JUL & AUG & SEP & OCT & NOV & DEC \\
\hline \multicolumn{13}{|l|}{ INDEX: } \\
\hline 2002 & 141.4 & 144.0 & 142.9 & 141.7 & 140.6 & 141.4 & 142.8 & 143.7 & 144.9 & 145.7 & 148.0 & 151.7 \\
\hline 2003 & 153.1 & 155.5 & 158.4 & 159.8 & 160.6 & 160.3 & 160.9 & 161.3 & 161.9 & 163.1 & 164.4 & 169.0 \\
\hline 2004 & 174.1 & 175.7 & 177.5 & 178.9 & 179.2 & 178.7 & 179.3 & 179.1 & 179.2 & 180.2 & 181.2 & 184.7 \\
\hline \multicolumn{13}{|c|}{ MONTHLY VARIATION (\%): } \\
\hline 2002 & 1.6 & 1.8 & -0.7 & -0.9 & -0.7 & 0.6 & 1.0 & 0.6 & 0.9 & 0.6 & 1.5 & 2.5 \\
\hline 2003 & 0.9 & 1.6 & 1.8 & 0.9 & 0.5 & -0.2 & 0.4 & 0.3 & 0.4 & 0.7 & 0.8 & 2.8 \\
\hline 2004 & 3.0 & 0.9 & 1.0 & 0.8 & 0.2 & -0.3 & 0.3 & -0.1 & 0.0 & 0.6 & 0.6 & 1.9 \\
\hline \multicolumn{13}{|c|}{ YEAR ON YEAR GROWTH RATE (\%): } \\
\hline 2002 & 24.5 & 25.9 & 24.0 & 21.5 & 19.7 & 18.9 & 17.2 & 14.7 & 13.9 & 11.4 & 9.6 & 9.0 \\
\hline 2003 & 8.3 & 8.0 & 10.8 & 12.8 & 14.2 & 13.3 & 12.6 & 12.3 & 11.7 & 11.9 & 11.1 & 11.4 \\
\hline 2004 & 13.7 & 13.0 & 12.1 & 11.9 & 11.6 & 11.5 & 11.4 & 11.1 & 10.6 & 10.5 & 10.2 & 9.3 \\
\hline \multicolumn{13}{|c|}{ ACCUMULATED GROWTH RATE DURING THE YEAR (\%): } \\
\hline 2002 & 1.6 & 3.5 & 2.7 & 1.8 & 1.1 & 1.6 & 2.7 & 3.2 & 4.2 & 4.7 & 6.4 & 9.0 \\
\hline 2003 & 0.9 & 2.5 & 4.4 & 5.3 & 5.8 & 5.6 & 6.0 & 6.3 & 6.7 & 7.5 & 8.4 & 11.4 \\
\hline 2004 & 3.0 & 3.9 & 5.0 & 5.8 & 6.1 & 5.7 & 6.1 & 6.0 & 6.0 & 6.6 & 7.2 & 9.3 \\
\hline
\end{tabular}

Source: National Statistics Institute

The fall in inflation is linked, among other things, to the performance of the real sector of the economy, the moderate expansion of the money supply, and the favourable evolution of the public accounts. One should also mention the impact of the appreciation of the Metical against the Rand and the US dollar, which softened the pressure from the group of non-food commodities, associated with the continual rise in oil prices on the international and domestic markets.

Although it declined by $-0.1 \%$ in June, and was stationary in July, when looked at in accumulated and annual terms the Maputo city price index rose by $9.1 \%$ by the end of the year, rather than the $11 \%$ programmed. 
Unlike what happened in 2003, the evolution of inflation over the period has been strongly influenced by the index of non-food commodities, which, in accumulated terms, increased by $4.8 \%$. Of particular importance was housing which by December had risen by $22.4 \%$. These increases were associated with the continual rise of oil prices on the international and domestic markets, and the adjustment upwards of some prices fixed administratively. One should also mention that, albeit on a smaller scale, the depreciation of the metical against the rand had some influence on the evolution of the index, particularly in the behaviour of food prices.

\begin{tabular}{|c|c|c|c|c|c|c|c|c|c|c|c|c|}
\hline & JAN & FEB & MAR & APR & MAY & JUN & JUL & AUG & SEP & OCT & NOV & DEC \\
\hline \multicolumn{13}{|l|}{ INDEX: } \\
\hline 2002 & 144.1 & 146.0 & 145.0 & 145.4 & 145.6 & 147.1 & 148.6 & 149.4 & 149.6 & 150.2 & 153.0 & 157.5 \\
\hline 2003 & 157.1 & 160.7 & 164.9 & 166.9 & 169.7 & 168.3 & 168.3 & 169.4 & 170.6 & 172.3 & 173.8 & 179.2 \\
\hline 2004 & 184.4 & 185.3 & 187.1 & 189.6 & 190.8 & 190.7 & 190.7 & 189.8 & 189.5 & 190.6 & 192.7 & 195.5 \\
\hline \multicolumn{13}{|c|}{ MONTHLY VARIATION (\%): } \\
\hline 2002 & -0.2 & 1.3 & -0.7 & 0.3 & 0.1 & 1.1 & 1.0 & 0.6 & 0.1 & 0.4 & 1.9 & 2.9 \\
\hline 2003 & -0.3 & 2.3 & 2.6 & 1.2 & 1.6 & -0.8 & 0.0 & 0.6 & 0.7 & 1.0 & 0.9 & 3.1 \\
\hline 2004 & 2.9 & 0.5 & 1.0 & 1.3 & 0.6 & -0.1 & 0.0 & -0.5 & -0.2 & 0.6 & 1.1 & 1.5 \\
\hline \multicolumn{13}{|c|}{ YEAR ON YEAR GROWTH RATE (\%): } \\
\hline 2002 & 22.9 & 24.9 & 23.2 & 22.2 & 19.5 & 18.3 & 16.6 & 15.2 & 14.3 & 10.5 & 8.9 & 9.1 \\
\hline 2003 & 9.0 & 10.1 & 13.7 & 14.8 & 16.5 & 14.4 & 13.2 & 13.3 & 14.0 & 14.7 & 13.6 & 13.8 \\
\hline 2004 & 17.4 & 15.3 & 13.5 & 13.6 & 12.5 & 13.3 & 13.3 & 12.0 & 11.1 & 10.6 & 10.8 & 9.1 \\
\hline \multicolumn{13}{|c|}{ ACCUMULATED GROWTH RATE IN THE YEAR (\%): } \\
\hline 2002 & -0.2 & 1.2 & 0.5 & 0.7 & 0.9 & 1.9 & 3.0 & 3.5 & 3.6 & 4.1 & 6.0 & 9.1 \\
\hline 2003 & -0.3 & 2.0 & 4.7 & 6.0 & 7.7 & 6.9 & 6.9 & 7.5 & 8.3 & 9.4 & 10.4 & 13.8 \\
\hline 2004 & 2.9 & 3.4 & 4.4 & 5.8 & 6.5 & 6.4 & 6.4 & 5.9 & 5.7 & 6.3 & 7.5 & 9.1 \\
\hline
\end{tabular}

Source: National Statistics Institute 
PRICE INDEX - BEIRA - BASE DEC $1998=100$

\begin{tabular}{|c|c|c|c|c|c|c|c|c|c|c|c|c|}
\hline & JAN & FEB & MAR & APR & MAY & JUN & JUL & $A \cup G$ & SEP & OUT & NOV & DEC \\
\hline \multicolumn{13}{|l|}{ INDEX: } \\
\hline 2002 & 146.3 & 147.7 & 146.2 & 142.1 & 140.8 & 142.3 & 143.5 & 144.9 & 148.0 & 149.0 & 150.3 & 151.1 \\
\hline 2003 & 153.4 & 153.5 & 155.9 & 157.2 & 158.5 & 160.5 & 161.8 & 161.4 & 161.2 & 162.3 & 163.6 & 166.4 \\
\hline 2004 & 171.2 & 174.4 & 176.4 & 176.5 & 175.9 & 174.9 & 176.6 & 177.3 & 177.6 & 178.4 & 178.2 & 180.5 \\
\hline \multicolumn{13}{|c|}{ MONTHLY VARIATION (\%): } \\
\hline 2002 & 5.1 & 0.9 & -1.0 & -2.8 & -0.9 & 1.0 & 0.9 & 1.0 & 2.1 & 0.7 & 0.9 & 0.5 \\
\hline 2003 & 1.6 & 0.1 & 1.5 & 0.9 & 0.8 & 1.3 & 0.8 & -0.2 & -0.1 & 0.7 & 0.8 & 1.7 \\
\hline 2004 & 2.9 & 1.8 & 1.2 & 0.1 & -0.3 & -0.6 & 1.0 & 0.4 & 0.1 & 0.5 & -0.1 & 1.3 \\
\hline \multicolumn{13}{|c|}{ YEAR ON YEAR GROWTH RATE (\%): } \\
\hline 2002 & 28.4 & 25.5 & 22.9 & 17.7 & 18.2 & 18.9 & 17.3 & 14.2 & 14.8 & 14.9 & 11.7 & 8.5 \\
\hline 2003 & 4.9 & 4.0 & 6.6 & 10.6 & 12.5 & 12.9 & 12.8 & 11.4 & 8.9 & 8.9 & 8.8 & 10.2 \\
\hline 2004 & 11.6 & 13.6 & 13.2 & 12.3 & 11.0 & 9.0 & 9.1 & 9.8 & 10.1 & 9.9 & 9.0 & 8.5 \\
\hline \multicolumn{13}{|c|}{ ACCUMULATED GROWTH RATE IN THE YEAR (\%): } \\
\hline 2002 & 5.1 & 6.1 & 5.0 & 2.1 & 1.2 & 2.2 & 3.1 & 4.1 & 6.4 & 7.1 & 8.0 & 8.5 \\
\hline 2003 & 1.6 & 1.6 & 3.2 & 4.0 & 4.9 & 6.3 & 7.1 & 6.9 & 6.7 & 7.4 & 8.3 & 10.2 \\
\hline 2004 & 2.9 & 4.8 & 6.0 & 6.1 & 5.7 & 5.1 & 6.1 & 6.5 & 6.7 & 7.2 & 7.1 & 8.5 \\
\hline
\end{tabular}

Source: National Statistics Institute

PRICE INDEX - NAMPULA - BASE DEC $1998=100$

\begin{tabular}{|c|c|c|c|c|c|c|c|c|c|c|c|c|}
\hline & JAN & FEB & MAR & APR & MAY & JUN & JUL & AUG & SEP & OUT & NOV & DEC \\
\hline \multicolumn{13}{|l|}{ INDEX: } \\
\hline 2002 & 125.4 & 133.2 & 132.6 & 131.4 & 126.7 & 123.9 & 125.4 & 125.1 & 126.3 & 127.2 & 129.2 & 136.1 \\
\hline 2003 & 141.4 & 144.3 & 143.6 & 142.9 & 136.9 & 135.2 & 136.7 & 136.8 & 137.2 & 136.6 & 137.6 & 142.9 \\
\hline 2004 & 148.3 & 149.1 & 150.3 & 150.5 & 150.1 & 149.3 & 149.8 & 150.7 & 151.8 & 152.9 & 152.7 & 160.0 \\
\hline \multicolumn{13}{|c|}{ MONTHLY VARIATION (\%): } \\
\hline 2002 & 1.4 & 6.2 & -0.5 & -0.8 & -3.6 & -2.2 & 1.2 & -0.3 & 1.0 & 0.7 & 1.6 & 5.4 \\
\hline 2003 & 3.8 & 2.1 & -0.5 & -0.5 & -4.2 & -1.2 & 1.1 & 0.1 & 0.3 & -0.4 & 0.7 & 3.8 \\
\hline 2004 & 3.8 & 0.6 & 0.8 & 0.1 & -0.3 & -0.5 & 0.4 & 0.6 & 0.7 & 0.7 & -0.1 & 4.7 \\
\hline \multicolumn{13}{|c|}{ YEAR ON YEAR GROWTH RATE (\%): } \\
\hline 2002 & 23.2 & 32.0 & 30.8 & 29.1 & 25.3 & 22.3 & 20.6 & 14.7 & 11.5 & 8.1 & 7.9 & 10.0 \\
\hline 2003 & 12.7 & 8.3 & 8.3 & 8.7 & 8.0 & 9.1 & 9.0 & 9.4 & 8.7 & 7.5 & 6.5 & 5.0 \\
\hline 2004 & 4.9 & 3.3 & 4.7 & 5.3 & 9.6 & 10.4 & 9.6 & 10.2 & 10.7 & 11.9 & 11.0 & 11.9 \\
\hline \multicolumn{13}{|c|}{ ACCUMULATED GROWTH RATE IN THE YEAR (\%): } \\
\hline 2002 & 1.4 & 7.7 & 7.1 & 6.2 & 2.4 & 0.1 & 1.3 & 1.1 & 2.1 & 2.8 & 4.4 & 10.0 \\
\hline 2003 & 3.8 & 6.0 & 5.5 & 5.0 & 0.5 & -0.7 & 0.4 & 0.5 & 0.8 & 0.4 & 1.1 & 5.0 \\
\hline 2004 & 3.8 & 4.4 & 5.2 & 5.3 & 5.0 & 4.5 & 4.9 & 5.5 & 6.3 & 7.0 & 6.9 & 11.9 \\
\hline
\end{tabular}

Source: National Statistics Institute

Considering the results achieved in 2004, the rate of inflation projected for 2005 is between 7 and $8 \%$ 


\section{IV.4. BALANCE OF PAYMENTS}

Commodity exports in 2005 are forecast to reach 1,529 million dollars, which, compared with 2004, will represent a growth of about 5\%. Exports from the mega-projects continue to dominate the range of goods traded by Mozambique on world markets, contributing with about 1,132 million dollars.

TRADE BALANCE - 10^6 USD

\begin{tabular}{|l|rrrr|}
\hline & 2002 & 2003 & 2004 & $2005 \mathrm{PL}$ \\
\hline TRADE BALANCE & -582.7 & -627.8 & -302.0 & -629.0 \\
Exports (fob) & 680.2 & 1043.9 & 1451.9 & 1529.0 \\
$\quad$ Of which: Mega-projects & 436.9 & 680.9 & 1048.5 & 1132 \\
Growth Rate (\%) & & 53.5 & 39.1 & 5.3 \\
Imports (cif) & -1262.9 & -1671.7 & -1753.9 & -2158.0 \\
$\quad$ Of which: Mega-projects & 404.2 & -303.6 & -279.7 & -460.0 \\
\hline
\end{tabular}

For their part, commodity imports in 2005 are forecast to reach 2,158 million dollars, of which 460 million are imports by the mega-projects.

In 2005 it is expected that the deficit on the balance of services will worsen by about $74 \%$ compared with the previous year - that is, that the deficit will rise from 279.7 to about 486 million dollars.

BALANCE OF SERVICES - $10^{\wedge} 6$ USD

\begin{tabular}{|l|rrrr|}
\hline & 2002 & 2003 & 2004 & $2005 \mathrm{PL}$ \\
\hline BALANCE & -151.8 & -272.6 & -279.7 & -486.0 \\
Revenues & 454.3 & 303.9 & 255.6 & 407.0 \\
Expenditure & -606.1 & -576.6 & -535.2 & -893.0 \\
\hline
\end{tabular}

As for the entry of foreign exchange into Mozambique to finance investment, in 2005 this may undergo a decline of about $15 \%$ compared with the previous year, influenced by a decline in private loans, taking into account that an increase in direct foreign investment is expected.

PRIVATE FOREIGN LOANS AND FOREIGN INVESTMENT - 10^6 USD

\begin{tabular}{|l|rrrr|}
\hline & 2002 & 2003 & 2004 & $2005 \mathrm{PL}$ \\
\hline Private loans (disbursements) & 791.1 & 383.5 & 420.8 & 227.2 \\
Direct foreign investment & 156.3 & 336.7 & 131.9 & 242.9 \\
TOTAL & 947.4 & 720.2 & 552.7 & 470.1 \\
\hline
\end{tabular}




\section{MAIN DEVELOPMENTS BY SECTOR}

\section{V.1. SOCIAL AREA}

\section{A. EDUCATION}

In the area of Education in 2005, there will be continuing priority on expanding access and improving the quality of education. Strengthening institutional capacity at the various levels of educational administration will be a further priority.

\section{General Education}

\section{Expansion of Access to Education}

In 2005 the number of pupils in General Education is forecast to grow by about $18 \%$ in comparison with 2004, thus maintaining the growth trend recorded in previous years. By levels of education, sharper growth is forecast in the number of pupils in primary education. In 2005 it is envisaged that the school network will grow by about 7\% compared with 2004 .

The construction of schools at low cost will be promoted in 2005 with a view to expansion of access. Thus the pilot phase of the School Construction at Low Cost Programme will be undertaken in four provinces, namely Cabo Delgado, Nampula, Tete and Zambézia.

General Education: Pupil numbers in 2003/2005

\begin{tabular}{|l|r|r|r|c|c|r|r|r|r|r|}
\hline & \multicolumn{4}{|c|}{ Schools } & \multicolumn{5}{|c|}{ Pupils } \\
\cline { 1 - 4 } Level & Achieved & Achieved & Planned & \multicolumn{2}{|c|}{ Evolution (\%) } & Achieved & Achieved & Planned & \multicolumn{2}{|c|}{ Evolution (\%) } \\
\cline { 10 - 12 } & 2003 & 2004 & 2005 & 2004 & 2005 & 2003 & 2004 & 2005 & 2004 & 2005 \\
\hline EP1 & 8,071 & 8,373 & 8,761 & 3.7 & 4.6 & $2,825,971$ & $3,071,564$ & $3,620,850$ & 8.7 & 17.9 \\
EP2 & 950 & 1,116 & 1,352 & 17.5 & 21.1 & 355,618 & 409,279 & 512,272 & 15.1 & 25.2 \\
ESG1 & 125 & 140 & 153 & 12.0 & 9.3 & 141,795 & 168,798 & 187,066 & 19.0 & 10.8 \\
ESG2 & 29 & 30 & 35 & 3.4 & 16.7 & 18,291 & 21,350 & 23,140 & 16.7 & 8.4 \\
\hline Total & 9,175 & 9,659 & 10,301 & 5.3 & 6.6 & $3,341,675$ & $3,670,991$ & $4,343,328$ & 9.9 & 18.3 \\
\hline
\end{tabular}

Source: MINED

\section{Pre-school Education}

In the area of Pre-school Education, the following activities will be undertaken in 2005:

- Develop and introduce experimentally training courses for monitors for the "Community Creches"; 
- Develop the Parental Education Programme, through the radio, and of the Literacy and Adult Education programmes, in order to ensure care and education for children.

\section{Special Education}

In the area of Special Education, the inclusion of children with special educational needs, children with motor disabilities, and blind and deaf children will continue. The rehabilitation of two special schools will also be undertaken.

\section{Primary Education}

About 3.6 million children are forecast to attend First Level Primary Education (EP1), which is an increase of $17.9 \%$ compared with 2004 . These pupils will attend 8,761 schools, which is an increase of $5 \%$ on the 2004 figure.

In terms of the school coverage rate, the net EPI enrolment rate is forecast to rise from the current $75.6 \%$ to $79 \%$ and the gross admission rate should rise by $19.1 \%$, from the current $137.6 \%$ to $156.7 \%$.

As for gender, it is expected that net EPI enrolment rate of girls in 2005 will reach $77 \%$ (3.8\% more than in 2004), and that the percentage of EP1 pupils who are girls will rise from the current $45.9 \%$ to $47 \%$.

At the same time, and as part of implementing the Gender Strategy in Education, the gender parity plan of action and the strategy to care for and assist orphans and vulnerable children will be implemented.

In Second Level Primary Education (EP2), the number of pupils in 2005 is forecast to grow by about $25 \%$ compared with 2004 . That is an increase of a further 102,993 pupils on the 409,279 pupils enrolled in 2004 . Thus the trend to strong growth in this level of education is continuing. That growth has been under way since 1995, and particularly since 2000 . As a result, the gross enrolment rate in this level will rise from the current $41.0 \%$ to $51.1 \%$ in 2005 .

As for schools, it is envisaged that a further 236 schools will provide this level of education in 2005, thus increasing the number of schools teaching EP2 from the current 1,116 to 1,352 .

In terms of entry, 216,700 pupils are forecast to enter 6th grade for the first time in 2005 , which is a rise of $15.2 \%$ compared with the 2004 figure. The gross admission rate will rise from the current $37.5 \%$ to $43.1 \%$ in 2005 , thus maintaining the growth trend noted since the 1995 school year. 


\section{Secondary education}

About 187,100 l pupils are forecast to attend the 1st Cycle of Secondary Education (ESG1) in 2005, which is a growth of $10.8 \%$ when compared to the figures observed in 2004. These pupils will attend a total of 153 schools, which is an increase of 13 on the number of schools which taught this level of education in 2004 (140 schools).

As for the Second Cycle of Secondary Education (ESG2), in 2005 about 23,100 pupils will attend these grades, which is a increase of $8.4 \%$ on the 2004 figure $(21,400$ pupils). This level of education will be taught in 35 schools, five more than in 2004.

\section{Distance Learning}

- Implementation of the Secondary Education Distance Learning Project (PESD) and its expansion to a further 5 districts in Nampula province;

- Development of a plan to implement the pilot 11th/12th grades project, under the Distance Learning in Mozambique strategy;

- Establishment of the National Distance Learning Institute (INED) and of the national network of Provincial Distance Learning Centres;

- Development of strategies to improve the quality of distance learning programmes;

- Training the staff involved in distance learning;

- Development of a joint programme with the UP for training secondary school teachers through distance learning;

- Registration of 5,000 teachers for the mid-level teacher training course by correspondence;

- Registration of 1,625 new teachers on the basic $\left(7^{\text {th }}+3\right)$ teacher training course by correspondence;

\section{Teacher training}

The training of the teaching staff will continue in 2005, in the framework of the efforts under way in the education system to raise the teachers' professional qualifications. 
During 2005, there will be a reflection on teacher training strategy, seeking to upgrade teachers at all levels so as to respond to the imperatives of Technical and Professional Training.

Thus it is expected that in 2005 a total of 5,541 students will attend the 7 th +3 teacher training courses (CFPPs), slightly less than the number attending in $2004(5,853)$, which is a decline of $-5,3 \%$. This course will be taught in 11 colleges located in all the provinces except Maputo City.

As for the mid-level teacher training courses (IMAPs), it is envisaged that in 2005 a total of 4,057 students will attend the 10 existing IMAPs, which is a slight growth, of $0.4 \%$, on the number of students registered in 2004 .

Training of the Teaching Staff

\begin{tabular}{|l|r|r|r|c|c|}
\hline \multicolumn{1}{|c|}{ Level } & Achieved & Achieved & Planned & \multicolumn{2}{|c|}{ Evolution(\%) } \\
\cline { 5 - 6 } & 2003 & 2004 & 2005 & 2004 & 2005 \\
\hline CFPP's (Basic) - Total students & 5,193 & 5,853 & 5,541 & 12.7 & -5.3 \\
IMAP's (Mid-level) - Total students, day & & & & & \\
course (Mid-level) - Total students, night & 3,841 & 4,040 & 4,057 & 5.2 & 0.4 \\
IMAP's (Mid-l, & 1,708 & 2,243 & 2,259 & 31.3 & 0.7 \\
course & 10,742 & 12,136 & 11,857 & 13.0 & -2.3 \\
\hline Total
\end{tabular}

Source: MINED

$\underline{\text { In-service teacher training }}$

- Continue the "CRESCER" programme of in-service teacher training;

- Undertake national programmes of continuous professional development for teachers and trainers at all levels based on the CRESCER experience.

Technical and Professional Education

In this educational sub-system, it is envisaged that in 2005 elementary technical education will be taught in 11 schools with a total of 1,717 students, which is an increase of $35.4 \%$ on the 2004 figure (1,268 students).

In 2005 , the basic level day course will be attended by a total of 20,316 students, an increase of $2.2 \%$ on the figure for 2004 (19,878 students).

The mid-level day course will be attended by 3,917 students, which is a rise of $11.4 \%$ compared with the figure for the current academic year (3,516 students).

In the field of culture, a reflection will be undertaken seeking to include the Arts Schools in the National Education System. 


\section{Adult Education}

In the area of literacy and adult education, it is envisaged that in 2005 a total of 810,00 students will attend the 1 st and 2 nd years, which is an increase of $50.7 \%$ on the number observed in 2004 (537,600 students). Of this number, 645,900 will be enrolled in the normal literacy programmes, and the rest $(164,100)$ will be included in literacy activities via radio. The number of units that it is forecast will teach this level of education is 6,347 , a much larger number than the 5,288 that existed in 2004.

For the $3^{\text {rd }}$ year it is proposed that in 2005 a total of 189,800 students will attend, which is a growth of $53.9 \%$ on the number observed in 2004 (123,300 students).

Achieving the above targets will rely on the participation of civil society, whose support has been important, particularly in Non-Formal Education, which involves programmes of improving the living conditions of citizens, and thus contributing in creating opportunities for reducing absolute poverty. With regard to the analysis of effectiveness, for the first time in the country, a data base and instruments for gathering and treating data in this area will be used.

\section{Improving the Quality of Education}

With the purpose of improving the quality of education, the following are planned for 2005:

- Implement the new curriculum nationally in $2^{\text {nd }}, 4^{\text {th }}$ and $7^{\text {th }}$ grades;

- Continue the process of transforming the curriculum of General Secondary Education;

- Reach an EP1 finishing rate of $48 \%$;

- Reduce the EP1 repetition rate to $15.6 \%$;

- Reach an EP1 finishing rate for girls of $41 \%$;

- Adopt the new curriculum in the teacher training institutions (CFPPs and IMAPs);

- Establish the comprehensive in-service training programme, serving the needs of $40 \%$ of EP1 and EP2 teachers;

- Implement in all public schools the Direct Support to Schools programme;

- Set up new ZIPs and continue revitalising those that already exist;

- Distribute the free school text books and other education resources; and

- Continue school building activities.

In the area of school sports and health, the following activities will be prioritised: 
- Hold the 7th National School Sports Festival;

- Distribute first aid medical kits in 10 provinces, in order to help improve the health of children at school; and

- Remove parasites from EP1 pupils in Gaza and Inhambane provinces and in Muanza and Dondo districts in Sofala.

In the HIVIAIDS area, the following activities will be undertaken:

- Expand the multi-sector programme on Sexual and Reproductive Health for adolescents and young people to 2 more provinces (Niassa and Inhambane). The programme will thus be present in 8 of the country's provinces;

- Introduce and implement a new prevention programme entitled "Basic Life Skills Package" in 3 provinces (Zambézia, Tete, Cabo Delgado);

- Implement the radio programme "World without Secrets" in 3 provinces (Zambézia, Tete e Cabo Delgado);

- Draft and distribute a manual on School Health and HIVIAIDS, along with a specific fund for activities on these topics, for all basic education schools (together with the Direct Support to Schools programme);

- Implement the 2nd phase of the programme for school directors entitled "Managing Schools in the context of HIVIAIDS";

- Print and distribute 80,000 copies of the brochure "HIVIAIDS and You";

- Introduce the pilot programme of support for orphaned and vulnerable children (COV's), benefiting about 50,000 children;

- Hold a national competition aimed at students on preventing and mitigating the effects of HIVIAIDS;

- Select and introduce indicators on the impact of HIVIAIDS on the sector, in the statistical survey system in force; and

- Train provincial focal points and working groups throughout the country in matters of HIVIAIDS, management and planning.

\section{Institutional Development}

In the area of strengthening the system's administrative and management capacity, priority will be given to training school directors and managers of the system at provincial and district level and developing partnerships with civil society. 
2005 will see the start of implementing the Education Strategic Plan (PEE) for the period 2005-2009. To ensure that the funds allocated to the sector are fully disbursed in due time, expenditure reports will be drawn up for analysis at the annual PEE review meeting.

In the area of involving the community in Education, the School Councils Manual will be distributed, and provincial and district teams will be set up to deal with the functioning of the School Councils.

Furthermore, the education management documents will be revised and enriched, at school, district, provincial and central levels, seeking to improve the circulation of information and the taking of decisions.

In the human resource area, challenges for the sector in 2005 are to finish regularising the pending cases of staff not yet formally in the system, appoint to effective positions staff who have concluded academic levels, but whose placing in the career structure was not changed earlier for lack of coverage in the budget, and upgrade the financial managers who deal with processing staff wages.

\section{HIGHER EDUCATION}

In 2005 higher education will continue to prioritise development of a work force capable of responding scientifically and technologically to the major challenges of the country's economic development. Special attention will be paid to expanding access to higher education through polytechnics in strategic areas for national development and in provinces where higher education institutions do not yet exist, to improving the quality of the courses given and to expanding education opportunities from citizens outside Maputo through expanding the higher education institutions.

To achieve these objectives, the following activities will be undertaken:

In improving the quality and relevance of higher education

- Establish the national system of accumulating and transferring academic credits;

- Set up the national accreditation, assessment and quality guarantee system;

- Introduce and monitor implementation of internal assessment and quality guarantee mechanisms in the higher education institutions;

- Define and approve staff statutes in public higher education;

- Train teaching staff through strengthening the existing programmes, prioritising the training of teachers for secondary education, which is determinant for the quality of this education and for the professional 
orientation of the students;

- Set up a scholarship fund in order to promote the opening, consolidation and growth of post-graduation programmes;

- Improve coordination between the various levels of education as one way of guaranteeing quality;

- Promote initiatives and/or finance activities to improve quality in the higher education institutions (QIF — Quality Improvement Fund);

- Conclude the definition of a Policy of Access to Public Higher Education;

- Make supervisory visits to public and private higher education institutions; and

- Harmonise academic degrees at SADC level.

Expand access to higher education with equity through:

- Start implanting higher polytechnic institutes in Gaza, Manica and Tete;

- Continue implanting distance learning with the creation of INED;

- Prepare the establishment of the National Scholarship Fund.

Improve administrative and financial management of the public higher education institutions through:

- Defining a Policy of Public Funding for Higher Education;

- Training staff of the public higher education institutions in the areas of administration and management;

- Promoting the financial and patrimonial autonomy of the public institutions;

- Make the PEES (2nd Phase) operational with the involvement of all public and private higher education institutions.

Develop scientific research in the higher education institutions through:

- Promoting research activities in post-graduate programmes in the higher education institutions in areas of knowledge that are important for national development, and for poverty reduction, particularly in the fields of education, agriculture, health, fisheries, energy, water, biotechnology, agro-processing, the environment, among others.

Contribute to the transfer of technology and innovation through:

- Promoting the role of educational institutions in disseminating science and technology, for example, through scientific conferences and publications. 
As for the specific activities to be undertaken in 2005 by the public higher education institutions, the following are envisaged:

\section{Eduardo Mondlane University (UEM)}

So that the education provided may attain excellence, and as a result of the curriculum reform under way, the UEM in 2005 will continue to prioritise the introduction of new methods of teaching and assessment, updating the libraries and improving educational resources with the support of information technologies.

Thus, to achieve the objectives defined, the following are envisaged:

\section{Teaching-Learning}

- Finance activities that seek to improve the admission system;

- Introduce systems of credit and assessment of teachers by students;

- Adjust the currícula to the introduction of the credits system;

- Introduce student-centred teaching methods;

- Produce material to publicise courses and to advise candidates;

- Prepare the new pedagogic regulations and other pertinent legislation;

- Assess the masters' courses;

- Equip and computerise the libraries;

- Equip the laboratories;

- Undertake activities linked to curriculum reform;

- Continue the upgrading/training of teachers at the pedagogic and postgraduate level; and

- Support the opening of new courses (Higher School of Marine Sciences and Oceanography in Quelimane).

\section{$\underline{\text { Research }}$}

Quality in education imposes a greater dynamic in research, which should capitalise on the constant increase of teachers doing post-graduate work and on the creation and development of centres of excellence.

Thus, in the research area, and to ensure excellence and quality, the following are envisaged:

- Finance 15 new research projects; 
- Hold the 4th research seminar;

- Set up a working group to formulate research policy;

- Hold monthly public lectures on results from the work undertaken and proceed to define lines of research; and

- Increase the participation of UEM teachers and researchers in international scientific events.

\section{Extension}

Extension is one of the vital components of the UEM's mission. In this context, the University possesses support centres, one of which is the Judicial Practice Centre of the Law Faculty, which provides legal assistance to the neediest members of the community. Thus, in 2005, the Centre will introduce the component of field work, imposed by the need to intervene in preventing damage to the fundamental rights of citizens.

\section{Expansion of the UEM in Mozambique}

The country's higher education sub-system does not yet meet the needs in terms of training qualified cadres. Furthermore, the number of places offered does not meet the growing needs and the demand that will be felt in the future. This situation demands expansion of the sub-system.

To face the need for expansion, in 2005 it is planned to acquire installations for the operations of the Higher School of Marine Sciences and Oceanography in Quelimane.

\section{Pedagogic University}

In 2005 expansion of access and improving the quality of the teachers trained will remain the priority. Thus the University will continue to prioritise the building of infrastructures, curriculum revision and the development of institutional capacity.

In this context, and in order to achieve the objectives laid down, the following activities will be undertaken:

\section{Expansion and strengthening of institutional capacity}

- Establish conditions for setting up new university campuses in Maputo, Beira, Nampula and Quelimane;

- Equip the institution and install a modern communications system; and 
- Design qualifications programmes for the technical and administrative staff. Implement new currícula

- Hold monitoring seminars as part of the introduction of new study plans.

Teaching, research and extension

- Hold staff training seminars;

- Hold the 2nd National Meeting on Educational Research in Mozambique; and

- Consolidate the Pedagogic University's publishing branch.

Post-graduation

- Continue the 1st Masters' Course in Education;

- Prepare the Masters' Course in Mathematics and Portuguese; and

- Continue post-graduate (masters and doctoral) studies abroad.

\section{Higher Institute of International Relations}

In 2005 the expansion of training areas in international relations and public administration are the main objectives to be pursued within the efforts under way to train and graduate professionals with the quality required to meet demand on the labour market.

Thus in 2005 attention will remain concentrated on expanding teaching with the introduction of new courses (Public Administration Course); on improving the quality of education through curriculum reforms, research, and the introduction of new technologies and methodologies of administration in teaching and learning, and in the training of teaching staff.

\section{B. SCIENCE AND TECHNOLOGY}

In this area, the government will implement the Science and Technology Policy, the general objective of which is to develop an integrated system for the production and management of knowledge directed at national needs so as to stimulate the sustainable development of the country.

Information and Communication Technologies will continue to play a fundamental role in improving the quality of education, as well as to impress a greater dynamic on administrative activities, guaranteeing efficiency in attending to the concerns of the public. Thus there will be continued promotion of scientific and 
technological innovation to make the country more competitive in the region and in the world.

Thus the activities to be pursued in $\mathbf{2 0 0 5}$ are as follows:

- Dissemination of the Science and Technology Policy and definition of the strategy and mechanisms for implementing it, with identification of priority areas on which to concentrate;

- Establishment of a forum with the objective of guaranteeing that coordination of national and international partners promotes integrated development programmes;

- Establishment of the institutional basis for implementing the Science and Technology Policy, prioritising the creation of three provincial directorates and upgrading the provincial reflection groups;

- Implementation of a national expedition of scientists and researchers to diagnose the main obstacles to development which can be analysed and solved from the technological point of view;

- Creation of a National Fund for scientific research;

- Establishment of sector scientific councils in four priority areas (water, agriculture, health and energy) and formulation of strategic plans for research in these four areas;

- Implementation of a prize-giving system for scientific work;

- Creation of the first national scientific journal;

- Promotion of initiatives and funding for applied research activities and innovative processes;

- Promotion of scientific research and encouragement for programmes of cooperation between technical and professional education, polytechnics and the local business class;

- Creation of an incubator for the agricultural area;

- Establishment of Multimedia Community Centres at district level;

- Creation of the virtual sugar museum;

- Formulation of a research strategy for the biotechnology area;

- Formulation of an ethical code of conduct for researchers, and a proposal for its implementation;

- Launch of the Mozambican Institute of Information and Communication Technologies, with at least one anchor company in Maputo province being the first technology park in the country; 
- Implementation of the «Equamat» competition as a way of supporting mathematics teaching and the use of information and communication technologies in secondary schools in at least three provinces;

- Creation of the Academy of Sciences of Mozambique;

- Organisation, in collaboration with partners in the area, of the $3^{\text {rd }}$ Mozambican Exhibition of Science and Technology;

- Drafting proposals for agreements and regulations that seek to coordinate the Sector with the institutions with executive responsibilities in the area of scientific research;

- Holding olympiads in the area of information and communication technologies; and

- Developing the institution through drawing up its statutes, staff table, training programme and other activities.

\section{HEALTH}

In the area of health, the priority will remain increasing access and improving quality in the provision of primary health care, in the context of reducing excessive mortality and morbidity among the population at large, and in the high risk and poor groups in particular.

\section{Provision of Health Care}

In this area, the main objectives for 2005 are the following:

- Institutionalise the Quality Guarantee Programme in the framework of consolidating the quality of health care and services; and

- Maintain the evolution of the overall volume of activities, and reduce geographical disparities in the consumption of health services.

\begin{tabular}{|c|c|c|c|c|c|}
\hline \multicolumn{6}{|c|}{ Evolution of Overall Health Activity, $2002-2005$} \\
\hline Indicators & $\begin{array}{c}2002 \\
\text { Achieved }\end{array}$ & $\begin{array}{c}2003 \\
\text { Achieved }\end{array}$ & $\begin{array}{c}2004 \\
\text { Forecast }\end{array}$ & $\begin{array}{c}2005 \\
\text { Planned }\end{array}$ & $\begin{array}{c}\text { \% Growth } \\
2005\end{array}$ \\
\hline \multicolumn{6}{|l|}{ OVERALL ACTIVITY } \\
\hline Care Units ('000) & 62,896 & 67,298 & 72,000 & 76,320 & 6 \\
\hline Care units/Inhabitant & 3.60 & 3.80 & 3.80 & 3.90 & \\
\hline \multicolumn{6}{|c|}{ EXTERNAL CONSULTATIONS } \\
\hline External Consultations ('000) & 15,336 & 17,058 & 17,265 & 18,076 & 5 \\
\hline External consultations/Inhabitant & 0.85 & 0.92 & 0.91 & 0.93 & \\
\hline
\end{tabular}

Source: MISAU 


\section{Expanded Vaccination Programme (PAV)}

In this area, in 2005 efforts will be undertaken to attain the following objectives:

- Reduction in mortality and morbidity from diseases that can be prevented through vaccination of children aged 0-23 months, children in the initial grades of school, and women of child-bearing age (15-49 years);

- Increased availability of equipment and assorted materials for the operation of the Programme with greatest attention to the areas with the greatest shortfalls;

- Strengthening the quality of data on PAV; and

- Holding the vaccination campaign against measles among children aged 9 months to 14 years old.

\begin{tabular}{|l|c|c|c|c|c|}
\hline \multicolumn{1}{|c|}{ Evolution of the coverage rates of the Expanded Vaccination Programme, 2001-2005, \% } \\
\hline & 2001 & 2002 & 2003 & 2004 & 2005 \\
& Achieved & Achieved & Achieved & Forecast & Planned \\
\hline BCG [0-11 Months] & 97 & 97 & 109.7 & 98 & 98 \\
VAS [9-23 Months] & 94 & 94 & 96.6 & 98 & 98 \\
DPT/HB (3rd Dose) & 82 & 87 & 91.5 & 98 & 95 \\
Anti-Polio (3rd Dose) & 82 & 87 & 89.6 & 98 & 95 \\
VAT-2a Pregnant Women & - & - & 56.9 & 60 & 75 \\
VAT-2 2 Women 15-49 years & - & 7.1 & 16.4 & 25 & 35 \\
\hline
\end{tabular}

Source: MISAU

Mother and Child Health and Family Planning Programme (SMI/PF)

In this area, the main objectives for 2005 are the following:

- Reduction of the hospital maternal mortality rate to $0.16 \%$;

- Reduction of the rate of hospital deaths among new-born infants;

- Increased accessibility and availability of essential, basic and complete obstetric services;

- Reduction of the number of neo-natal deaths from asphyxiation, premature birth, and hypothermia;

- Improvement in care for newly born infants;

- Provide more health professionals with the skills to offer quality emergency obstetric care for women in childbirth, particularly for the rural areas; and

- Establishment of quality standards and criteria for services provided for children. 


\begin{tabular}{|c|c|c|c|c|c|}
\hline \multicolumn{6}{|c|}{ Evolution of Coverage Rates of Mother and Child and Family Planning Programme, 2001-2005, \% } \\
\hline Indicators & $\begin{array}{c}2001 \\
\text { Achieved }\end{array}$ & $\begin{array}{c}2002 \\
\text { Achieved }\end{array}$ & $\begin{array}{c}2003 \\
\text { Achieved }\end{array}$ & $\begin{array}{c}2004 \\
\text { Forecast }\end{array}$ & $\begin{array}{c}2005 \\
\text { Planned }\end{array}$ \\
\hline Ante-natal consultations & 100 & 100 & 109.5 & 99.5 & 100 \\
\hline Institutional births & 41.2 & 43 & 54.1 & 47 & 49 \\
\hline Post-natal consultations & 50.5 & 53.8 & 57.4 & 54 & 58 \\
\hline Family Planning (New Users) & 15.26 & 16.72 & 17 & 18 & 20 \\
\hline $1^{\text {st }}$ consultation children (0-11 Months) & 96 & 97 & 98 & 98 & 98 \\
\hline $1^{\text {st }}$ Consultation children (0-4 Years) & 62 & 64 & 66 & 68 & 70 \\
\hline
\end{tabular}

Source: MISAU

In the area of the School and Adolescent Health Programme, in 2005 it is planned:

- To set up health services adequate to the needs of school and adolescent health;

- To train health professionals to work with adolescents, in Family Planning, treating abortion complications, and preventing and treating HIVIAIDS;

- Strengthen technical capacity at central and provincial levels;

- Improve the system and mechanisms for coordination with other institutions;

- Approve and publicise the Policy of Adolescent Reproductive Health; and

- Expand implementation of specific reproductive health services for adolescents and young people.

In the area of nutrition, the following will be prioritised in 2005:

- Educational activities on appropriate dietary habits;

- Reduction in micro-nutrient deficiency through distributing Vitamin A capsules to all children aged 6-59 months, during growth control consultations;

- Implement the Nutritional Rehabilitation Programme in its components of training, equipment and making products available;

- Promotion of production and consumption of foods rich in micro-nutrients;

- Promotion of the availability and consumption of iodised salt;

- Promotion of appropriate processing of bitter cassava in Zambézia and Nampula provinces; and

- Promotion of breast milk, and adequate complementary feeding.

Thus, it is hoped that the proportion of children with insufficient weight falls to $6 \%$ and that the proportion of children born in hospital with low weight at birth is no more than $10 \%$. 


\section{Major endemic diseases}

In this area, in 2005 priority will be given to the prevention, control and treatment of the main epidemic diseases that have most influence on the morbidity and mortality of the population. Thus, among others, the following activities will be undertaken:

\section{HIVIAIDS}

Under implementation of the Strategic Plan against HIVIAIDS, efforts will be made to guarantee anti-retroviral treatment to 20,800 people and to prevent vertical transmission.

\section{Malaria}

- Promote the use of insecticide-treated mosquito nets throughout the country;

- Treatment of cases of fever in the community in accordance with the habits prevailing in the communities;

- Promotion of integrated treatment of childhood diseases and of ante-natal treatment for women in 20 districts; and

- Spraying with residual insecticides where recommended.

As a result of these actions, it is expected that in 2005 a hospital lethality rate from malaria among children and adults of $2.7 \%$ and $5.3 \%$, respectively will be reached.

\section{$\underline{\text { Tuberculosis }}$}

- Introduction of the 6 month tuberculosis treatment regime, with drugs in combined fixed doses;

- Reduction of patients abandoning treatment to less than $10 \%$;

- Strengthening the capacity and quality of staff, including laboratory staff, in the areas that most need this, through training and supervision; and

- Introduction of TPC (preventive treatment with cotrimoxazol) or anti-retroviral treatment for patients with HIV and Tuberculosis, gradually and wherever possible.

As a result of these actions, it is expected that the tuberculosis mortality rate will fall to $12 \%$ and that the percentage of new tuberculosis cases with positive cured basciloscopy reaches $75 \%$. 


\section{Leprosy}

- Expansion of the geographical coverage of drugs for TMA (therapy with associated medicines) through the involvement of more community volunteers; and

- Increase in information and education in the most endemic areas (Nampula and Zambézia).

\section{Pharmaceutical area}

In this area, efforts will continue in 2005 to improve the availability of medicines in health units, guaranteeing the consumption of safe, effective and good quality dugs. Thus the main objectives are as follows:

- Improved management in the supply of medicines to the provincial level and in the health units; and

- Timely distribution of the medicines requested.

\section{Expansion of the Health Network}

In this area, priority will be given to increasing access to health care through the expansion and rehabilitation of the health network. The following are planned for 2005:

\begin{tabular}{|l|c|c|c|}
\hline & Construction & Promotion & $\begin{array}{c}\text { Rehabilitation/Expansion/ } \\
\text { Change of function }\end{array}$ \\
\hline $\begin{array}{l}\text { Hospitals } \\
\text { Health }\end{array}$ & 1 & 2 & 10 \\
Centres & 12 & - & 14 \\
$\begin{array}{l}\text { Stores } \\
\text { Science }\end{array}$ & 1 & - & - \\
Institute & 2 & - & - \\
$\begin{array}{l}\text { Laboratories } \\
\text { Administrative }\end{array}$ & 1 & - & - \\
Services & 4 & - & 5 \\
\hline
\end{tabular}

$>$ Construction of the Matola General Hospital

$>$ Conversion of the Health Centre at Caia into a Rural Hospital, and of the Health Centre at Gorongosa into a District Hospital

$>$ Construction of the medical stores in Beira

$>$ Construction of the Infulene and Quelimane Health Science Institutes

$>$ Construction of the National Drug Control Quality Laboratory. 
In the area of developing human resources, in 2005 initial and continual training of workers will be prioritised, in order to improve constantly their professional performance.

As for Institutional Development, greater attention will be paid to strengthening the organisation and management of the health care system, including aspects of training in leadership and planning.

Under the Strategic Health Plan (PESS), 2005 will see the revision of the plan for the period 2006-2010, and leadership and management courses will be held in the health services, with greatest stress on the rural areas.

\section{LABOUR}

In the area of labour, the main objectives in 2005 will be on improving the general business environment so as to attract more private investment to the country, on job creation, and on institutional capacity building, with the purpose of reducing absolute poverty. A further priority will be implementing labour laws and regulations, and extending services of the social security system to the entire country.

To achieve the objectives defined, the following are envisaged:

Normative Action

- Conclude the revision of the Labour Law;

- Draw up, in coordination with the social partners, a draft diploma for the introduction of public and private labour mediation, conciliation and arbitration; and

- Draw up a draft diploma to expand the personal scope of the Social Security System to cover waged workers of the informal sector, independent workers and the self-employed.

\section{Employment, labour and professional training}

- Identify job opportunities for 4,000 job seekers;

- Train professionally 2,000 unemployed, including disabled people, registered at the job centres;

- Promote apprenticeships for 600 graduates from the technical schools and institutes, in the coordination of formal education with professional training in companies; 
- Upgrade the training sector for management training of micro and small business people;

- Train 220 women organised in associations, in management of micro and small businesses;

- Prepare and analyse proposals for productive micro-projects to be financed under FARE, seeking to create job opportunities for their beneficiaries;

- Accompany and evaluate the Project for Social Reinsertion of former miners in Magude, Chókwè and Massinga districts;

- Support financially and accompany implementation of 200 self-employment projects;

- Control the recruitment, hiring and legalisation of Mozambican workers abroad;

- Continue the construction and equipping of the Lichinga, Quelimane, Pemba and Vilanculos professional training centres;

- Rehabilitate and equip the Chimoio professional training centre;

- Rehabilitate the premises of the Employment Promotion Office in Maputo, Manhiça and Chibuto; and

- Produce regular information bulletins on registered unemployment, strikes, work accidents, social security, migrant labour and professional training.

\section{Professional Relations}

- Promote tripartite social dialogue and free collective labour bargaining in companies; and

- Inspect 5,000 establishments in various areas of activity throughout the country.

\section{Social Security}

- Draft a proposal to revise funeral benefits and encourage the voluntary maintenance of the registration of unemployed workers;

- Open district directorates and/or representations in Monapo, Malema, Namapa, Chibuto and Mocímboa da Praia; and

- Register 1,600 companies and 30,000 workers in the social security system.

Strengthening institutional capacity

- Build new premises for the Ministry of Labour;

- Rehabilitate and expand the premises of the Studies Office and the Documentation and Information Centre (CDI); 
- Hold professional training seminars for 34 employment staff;

- Provide additional training to 12 labour administration agents;

- Recycle 30 labour inspectors and train 20 new labour inspectors;

- Finish the computerisation of the social security system; and

- Finish building premises for the Gaza, Tete and Dondo delegations, and start building the Social Security premises in Zambézia and Nampula.

\section{E. WOMEN'S AFFAIRS AND SOCIAL ACTION}

In this area, attention will remain concentrated in 2005 on institutional development and capacity building, on raising the status of women, and on promoting gender equity, security, assistance and social integration for the target vulnerable groups, particularly children, the elderly and the disabled.

In this context, the following stand out among the various actions to be undertaken:

$\underline{\text { In the area of institutional development and capacity building }}$

- Continue drafting the Strategic Plan for the sector;

- Train, upgrade and improve the skills of staff working in the sector of women's affairs and social action;

- Improve the methodologies used to gather and analyse statistical data on the programmes and target groups;

- Design monitoring and evaluation instruments (with indicators disaggregated by sex), to measure the impact of protection and social reinsertion programmes;

- Continue regulating the operations of public and private social units; and

- Strengthen coordination and articulation with social actors.

In the area of promoting women's status

- Approve and publicise the National Gender Policy and Strategy;

- Continue activities to train, inform and counsel women;

- Guarantee the integration of a gender perspective in the policies, programmes and projects of the Government and in civil society organisations and the private sector; 
- Implant Provincial Councils for Women's Advancement, a well as gender units in the various government institutions; and

- Continue promoting awareness and social reinsertion of women victims of violence, and women living with HIVIAIDS.

In the area of child protection

- Draw up the National Plan of Action for Children and submit it for approval;

- Participate in revising legislation concerning children;

- Continue the integration of orphaned and abandoned children, and those living with HIVIAIDS;

- Continue developing income generating and professional training projects for street children, and those involved in child prostitution.

In the area of the Location and Family Reunification Programme, it is expected that in 2005 the number of children to be documented will grow by $7 \%$ in comparison with 2004 , due to family abandonment, natural phenomena and social ones such as violence, ill-treatment and the poverty of households, which contribute to the separation of children from their parents.

Location and Family Reunification Programme
\begin{tabular}{|l|r|r|r|c|c|}
\hline & 2003 & 2004 & 2005 & \multicolumn{2}{|c|}{ Evolution $\%$} \\
\cline { 5 - 6 } \multicolumn{1}{|c|}{ Indicators } & Achieved & Achieved & Planned & 2004 & 2005 \\
\hline Number of children documented & 1,197 & 932 & 1,000 & -22.1 & 7.3 \\
Number of children reunited & 429 & 300 & 300 & -30.1 & 0.0 \\
\hline
\end{tabular}

Source: MMAS

In the area of Pre-School Education, in 2005, priority will continue to be given to improving the quality of services provided to children, and to consolidating preschool education on a mass scale in rural and peri-urban areas.

At the same time, activities will be undertaken to make religious communities, NGOs and the private sector aware of the need to provide support to community initiatives concerning the building of more creches and the creation of sustainable methods for running them.

In this context, it is expected that in 2005, the number of children, private centres and community creches will increase, compared with 2004. 


Pre-school education
\begin{tabular}{|l|r|r|r|r|c|}
\hline \multicolumn{1}{|c|}{ Indicators } & 2003 & 2004 & 2005 & \multicolumn{2}{|c|}{ Evolution \% } \\
\cline { 5 - 6 } & Achieved & Forecast & Planned & 2004 & 2005 \\
\cline { 5 - 6 } Number of children's centres (state) & 15 & 15 & 15 & 0.0 & 0.0 \\
Number of children attending & 1,483 & 1,097 & 1,400 & -26.0 & 27.6 \\
Number of children's centre (private) & 103 & 100 & 100 & -2.9 & 0.0 \\
Number of children attending & 7,954 & 9,365 & 9,500 & 17.7 & 1.4 \\
Number of community creches & 533 & 450 & 500 & -15.6 & 11.1 \\
Number of children attending & 37.410 & 29,000 & 30,000 & 22.5 & 3.4 \\
Number of monitors & 870 & 700 & 700 & -19.5 & 0.0 \\
\hline
\end{tabular}

Source: MMAS

In the areas of the psychological and social rehabilitation and integration of children under difficult circumstances, continued priority will be given to involving community organisations, religious institutions, NGOs and the private sector in caring for orphans and abandoned children in orphanages, accommodation centres and in communities.

Thus it is forecast that in 2005 the number of children cared for in state and private orphanages will rise by $40 \%$ and $4 \%$ respectively, compared with 2004 . The number of centres for street children will increase, while other kinds of centres will not.

Children under difficult circumstances

\begin{tabular}{|l|r|r|r|r|c|}
\hline \multicolumn{1}{|c|}{ Indicators } & 2003 & 2004 & 2005 & \multicolumn{2}{|c|}{ Evolution, \% } \\
\cline { 5 - 6 } & Achieved & Forecast & Planned & 2004 & 2005 \\
\hline Number of street centres & 71 & 70 & 80 & -1.4 & 14.3 \\
Number of children cared for & 10,659 & 8,700 & 9,000 & -18.4 & 3.4 \\
Number of orphanages (state) & 8 & 8 & 8 & 0.0 & 0.0 \\
Number of children cared for & 345 & 214 & 300 & -38.0 & 40.2 \\
Number of orphanages & 14 & 13 & 13 & -7.1 & 0.0 \\
(Private) & & & & & \\
Number of children cared for & 685 & 628 & 650 & -8.3 & 3.5 \\
\hline
\end{tabular}

Source: MMAS

In the area of care for the elderly, actions will continue in 2005 to assist them and promote their rights, and to integrate them in families and in the community. It is forecast that the number of elderly people cared for in private centres will decline in comparison with 2004, while the number in state centres will rise.

As an integral part of the efforts under way to support the elderly, in 2005 the following activities will be undertaken.

- Making communities aware of the need to set up Open Community Centres; and 
- Implementation of National Ageing Policy.

Programme of caring for the elderly

\begin{tabular}{|l|r|r|r|c|c|}
\hline & 2003 & 2004 & 2005 & \multicolumn{2}{|c|}{ Evolution, \% } \\
\cline { 5 - 6 } \multicolumn{1}{r|}{ Indicators } & Achieved & Forecast & Planned & 2004 & 2005 \\
\hline Old People's Homes (State) & 10 & 9 & 9 & -10.0 & 0.0 \\
No of old people cared for & 255 & 215 & 215 & -15.7 & 0.0 \\
Old People's Homes (Private) & 12 & 11 & 13 & -8.3 & 18.2 \\
No of old people cared for & 281 & 462 & 400 & 64.4 & -13.4 \\
\hline
\end{tabular}

Source: MMAS

In order to improve care for the disabled and encourage their integration into income generating activities, the following activities are envisaged in 2005:

- Boost school attendance by disabled children/youths in coordination with other state institutions and NGOs;

- Continue to place disabled adults who are able to work in micro-credit, income generation and professional training activities;

- Equip the premises for the Institute for the Visually Disabled in Beira;

- Continue efforts to promote participation by disabled people in sporting and cultural activities;

- Support the development of special education for disabled children from the perspective of inclusive education and physical rehabilitation; and

- Continue training/upgrading of sign language interpreters, and divulging sign language.

Care for the Disabled

\begin{tabular}{|l|r|r|r|c|c|}
\hline & 2003 & 2004 & 2005 & \multicolumn{2}{|c|}{ Evolution, \% } \\
\cline { 5 - 6 } \multicolumn{1}{r|}{ Indicators } & Achieved & Forecast & Planned & 2004 & 2005 \\
\hline Disabled people identified & 12,800 & 5,500 & 6,000 & -57.0 & 9.1 \\
Disabled people accompanied & 6,228 & 600 & 1,200 & -90.4 & 100.0 \\
Disabled children integrated & 2,165 & 3,400 & 3,000 & 57.0 & -11.8 \\
Number of transit centres & 8 & 6 & 6 & -25.0 & 0.0 \\
Disabled people cared for & 290 & 44 & 100 & -84.8 & 127.3 \\
Special Schools & 3 & 3 & 3 & 0.0 & 0.0 \\
Number of pupils & 308 & 207 & 300 & -32.7 & 44.9 \\
Institute for Visually Disabled & 1 & 1 & 1 & 0.0 & 0.0 \\
Number of pupils & 75 & 81 & 170 & 8.0 & 109.9 \\
\hline
\end{tabular}

Source: MMAS

In the area of support for drug addicts, the chronically ill, and prisoners, the following activities will be undertaken in 2005: 
- Continue educational programmes and establish community counselling groups on preventing and fighting against drug consumption;

- Promote support for the social, community and family reintegration of drug addicts and former prisoners, through education, professional training and income-generating programmes; and

- Design and implant experimentally a sustainable model of information, counselling, recovery and reinsertion for drug addicts and former prisoners.

\section{Programmes of direct social assistance and support for community development}

Assistance to the least privileged population groups living in absolute poverty, through the Food Subsidy and Income Generation programmes, will remain the priority in the efforts under way seeking to ameliorate poverty and promote employment for those able to work. Thus for 2005, among other actions, the following are planned:

\section{Under the Food Subsidy Programme}

- To assist more than 92,300 beneficiaries of the programme; and

- To continue divulging the Programme's procedures manual.

\section{Under the Social Benefits for Work Programme}

- To enrol 20,000 beneficiaries in the Programme; and

- To accompany and assess change or the socio-economic situation of the beneficiaries.

\section{Under the Income Generation Programme}

- To enrol 31,911 beneficiaries and support the development of savings systems in rural communities; and

- To train beneficiaries to handle their businesses better.

\section{Under the Community Development Programme}

- Mobilise resources and establish partnerships to implement community development integrated pilot projects (agricultural, livestock, industry, trade and basic social infrastructures) in all provinces.

\section{Under the Direct Social Support Programme}


- Provide support to 35,500 disabled people who are proved to be living in poverty.

\section{F. VETERANS OF THE NATIONAL LIBERATION STRUGGLE}

In this area, in 2005, the government will continue to orient its efforts towards valuing history and the better social insertion of the Veterans of the National Liberation Struggle though the following activities:

- Ensure the social insertion of Veterans of the National Liberation Struggle;

- Promote the creation and construction of monuments, museums, libraries and historical sites that document and illustrate the history of the National Liberation Struggle;

- Promote the collection of testimony and research on the history of the National Liberation Struggle;

- Draw up a project to build a centre for the training and the physical, psychological and social rehabilitation of veterans;

- Implement the Veterans' Statute.

\section{G. CULTURE}

In the area of culture, in 2005 attention will remain concentrated on preserving and publicising the national cultural heritage, in developing creativity and promoting the cultural industry.

\section{Cultural Heritage}

In the area of identifying, registering and preserving cultural works and values that represent the cultural and natural heritage, the following activities are planned:

- Conclusion of redefining the mechanisms for applying the Law on Protecting Cultural Heritage;

- Start drafting proposals for those items of the natural cultural heritage to be submitted for world heritage status;

- Draw up proposals for revising the legal framework for the cultural heritage area;

- Draw up a proposal to revise the Law Protecting Cultural Heritage, particularly as regards the classification of the built and urban heritage. 
To encourage the use of monuments, museums and other institutions of cultural preservation and publicity, the following activities will be undertaken in coordination with the education and tourism sectors:

- Definition and standardisation of the terms and concepts used in the area of tangible and intangible cultural heritage;

- Publicising projects of conserving, preserving and valuing heritage, and techniques of preserving intangible heritage;

- Begin drafting the proposal for revising museum regulations;

- Drafting manuals on techniques for the preventive preservation of tangible cultural heritage, and a national programme for conservation and restoration of museum collections;

- Implement the programme to celebrate national cultural diversity.

As for adopting measures conducive to actions envisaged in the Mozambique Island Restoration Programme, in 2005 it is planned to continue rehabilitating infrastructures on the Island, to create the Island Conservation Office and conclude drafting the Island Management Plan.

\section{Cultural Action}

In this area, efforts will be centred on promoting the training and upgrading of the managers and makers of culture. The following activities are envisaged:

- 1st National Seminar on Cultural Associations;

- National Seminar on Houses of Culture; and

- $\quad$ Training and upgrading cultural inspectors.

In order to publicise the vast artistic and cultural potential, the national institutions and makers of culture, and easy access to information in this area, the following activities are proposed:

- Development of the Data Bank project on the national artistic and cultural movement and potential;

- Commemoration of cultural dates (World Poetry Day, World Theatre Day, World Book and Copyright Day, International Dance Day, World Culture Day, Day of SADC Artists and Creators, World Cinema Day).

In the framework of improving conditions and expanding the supply of public spaces for cultural activities, areas for artistic and cultural creation will be created or rehabilitated. 
As for establishing a legal environment favourable to the development of artistic creativity and to the cultural industry, the following activities are proposed:

- $\quad$ Revision of the regulations on concerts (Seminars and debates);

- Regulations on filming in Mozambique;

- Drafting legislation on the circulation and sale of works of art and handicrafts.

In the area of civil education about HIVIAIDS, cultural sessions will be held, and technical staff in the cultural area in the communities will be trained.

In the area of training, managers, technical staff, cultural instructors and monitors, and directors of the houses of culture will be trained and upgraded.

To strengthen the protection of intellectual property, in the area of copyright it is planned to introduce a system to combat piracy of computer programmes, videos and DVDs.

To promote books, a taste for reading, and the book industry, the following activities will be undertaken:

- $\quad$ Submit the National Book Policy for approval by the Council of Ministers; and

- $\quad$ Prepare the project to introduce the International Book Numbering System in Mozambique.

\section{Institutional Development}

The construction and rehabilitation of cultural infra-structures, particularly the houses of culture, open air stages, provincial public libraries, historic sites (monuments), the buildings of art schools and museums, for cultural promotion and publicity, will continue to merit special attention.

\section{H. YOUTH AND SPORTS}

In the area of youth and sports, priority will continue to be given in 2005 to involving young people in the development of the country, in the fight against HIVIAIDS and in mass physical and sporting activity. Thus programmes will be implemented for the employment and professional training of young people, and to promote socio-cultural interchanges and the practice of mass sport, and high competition sport. 


\section{Youth}

In order to promote young people's participation in the country's development, in 2005 the priority will remain education, training, employment and housing programmes. In this context, among other activities, the following are planned:

- Provide technical and methodological assistance to institutionalise the Youth Initiatives Support Fund and make it operational;

- Provide technical, methodological and financial support to the National Youth Council, and to the establishment of Provincial and District Youth Councils;

- Guarantee that programmes to fight against STD/HIV/AIDS, and against illicit drug trafficking and consumption, are expanded and made operational;

- Strengthen inter-sector coordination mechanisms, by reactivating the Inter-Sector Adolescents and Young People Support Committee (CIADAJ);

- Provide technical and financial assistance to the Mozambique Scouts League (LEMO) in holding the $5^{\text {th }}$ African Scouts Festival;

- Encourage initiatives that generate employment, self-employment and other sources of income for young people under the National Integrated Social Action, Employment and Youth Programme.

\section{$\underline{\text { Sport }}$}

Mass participation in sports will continue to merit special attention. Thus there will be continued implementation of the school holidays sports programme, and the Mozambique in Movement Programme. Women's sports and sport for disabled people will be promoted. Holding the School Sports Festival will remain a government priority in stimulating mass participation in sport.

With the aim of raising the technical and scientific knowledge of cadres and trainers, training and upgrading activities will be held for sports technical cadres, monitors and leaders at national level.

Restoration, expansion, improvement and conservation of sports premises and equipment nationally will continue to receive special attention as part of the efforts under way seeking to install modern and properly equipped infrastructures in the country's main urban centres.

Encouragement will be given to setting up a national sports equipment industry. 


\section{ENVIRONMENT}

In the area of the environment, in 2005 activities will be pursued seeking to guarantee environmental preservation and an appropriate use of natural resources, prioritising environmental inspection, inter-sector coordination, and the involvement of communities in planning and using natural resources.

In this context, in 2005 the following actions will be prioritised:

\section{Inter-sector Coordination}

- Approve and implement the Environmental Strategy for the Sustainable Development of Mozambique;

- Set up inter-sector committees to control soil erosion, and prevent bush fires and deforestation.

\section{Environmental Management}

In the area of conserving natural resources, it is planned to:

- Draft the proposal for the National Strategy on community management of Natural Resources;

- Implement international conventions (on drought and desertification, climate change, biodiversity, and Ramsar on wetlands);

- Revise the National Plan of Action to combat drought.

In the area of coastal management, it is planned to formulate and implement coastal management policies/programmes in Mozambique, draw up a strategy on wetlands, and promote demonstrative actions on their management.

In the Urban Environment, priority will be given to developing strategies to combat environmental problems in the urban centres, particularly those associated with the management of urban solid waste, with the exploitation of green areas, and with urban pollution.

\section{Environmental Impact Assessment}

With the purpose of ensuring that economic and social undertakings operate in a perspective of economic, environmental and social sustainability, activities will be concentrated on the following:

- Environmental Impact Assessment (EIA) of development projects;

- Strategic Environmental Assessment (SEA);

- Prevention and control of environmental pollution; 
- Environmental audits of activities under implementation;

- Implementation of the system of licensing and environmental auditing;

- Setting up a system to manage dangerous wastes, and making it operational;

- Implement international conventions (Stockholm, Basle, Bamako, Vienna and the Montreal Protocol).

\section{Territorial Planning and Classification}

In this area, priority will go to the following:

- Following the drafting of plans on territorial classification, and implementing the information system at provincial level;

- Holding upgrading courses on territorial planning and classification, and organising seminars to divulge the legislation in force on the planning area;

- Train local bodies in the use of the new methodological guide for drafting territorial plans;

- Drafting norms and regulations for the Territorial Classification Policy;

- Draw up the programme of urban reclassification in some neighbourhoods of Maputo City and Pemba;

- Draw up structural plans for the towns of Mocuba, Metangula, Chókwè and Chimoio;

- Draw up partial plans for Mozambique Island and Nicoadala town;

- Draw up urbanisation plans for the settlements of Namialo, Inchope, Vila Franca do Save, Muxúngoe and Pambara;

- Draw up land use plans with priority for the Zambezi Valley;

- Draw up 9 district plans in the area of planning and finance in Zambézia, Sofala, Tete and Manica provinces.

\section{Environmental Promotion}

Information and education on the environment will continue to be prioritised, in order to guarantee sustainability in the exploitation of natural resources. Thus, in 2005 , it is planned to:

- Divulge policies and strategies relevant to the environmental sector;

- Promote the development of educational activities and environmental awareness;

- Promote campaigns of awareness about uncontrolled bush fires; 
- Make radio and television programmes, and publish educational magazines and brochures on environmental questions.

\section{Environmental General Inspectorate}

With the purpose of ensuring that every citizen lives in a healthy environment and enjoys social and economic well-being, environmental inspection activities will be undertaken of development projects, as well as administrative inspection at the level of the ministry.

\section{Environmental Legislation}

In the area of Environmental Legislation, the following activities will be undertaken:

- Draw up the Environmental Inspection Regulations;

- Draw up the Regulations of the Law on Territorial Planning and Classification;

- Draw up the Regulations on Waste Management;

- Draw up the Regulations on Preventing Marine and Coastal Pollution;

- Draft norms for the implementation of the Environmental Impact Assessment Regulations.

Institutional Capacity Building

In this area, in 2005 it is planned to:

- Set up the Environmental Statistics Office;

- Strengthen the planning system, so as to guarantee implementation of the Strategic Plan;

- Draw up and adopt indicators on sustainable development and on the performance of the Ministry;

- Develop institutional capacity building activities at all levels;

- Ensure integration of environmental matters into PARPA. 


\section{V.2 ECONOMIC AREA}

\section{A. AGRICULTURE}

In this sector, the actions to be undertaken in 2005 will prioritise activities in the sustainable use of natural resources with community participation, livestock assistance, encouragement of fruit trees, of cash crops such as cotton, paprika and tobacco, community reforestation, making appropriate technologies available to low cost within the reach of small producers through liaison between research and Rural Extension, simplification of the procedure for obtaining Land Use Title (DUAT), particularly for small producers, and actions seeking to conserve agricultural products in order to reduce post-harvest losses. Thus, the policy measures are as follows:

- Undertake inspections of local production of seeds and formal production in Inhambane and Maputo;

- Undertake multiplication of seeds and vegetative material in Maputo, Gaza, Sofala, Manica, Zambézia and Tete, and ensure that $16 \%$ of grain production is marketed;

- Distribute low cost processing machines in the zones producing root crops, grains and coconuts (5 for Maputo, 10 for Inhambane and Nampula and 5 for Zambézia);

- Transmit technological messages in all provinces;

- Produce and distribute cashew seedlings benefitting 38,000 household so as to promote new plantings of cashew trees;

- Continue implementing the CDRs and on-farm tests in Nampula, Niassa and Tete, and undertake the integrated management of cashew pests and illnesses in Nampula, Gaza, Zambézia, Maputo and Cabo Delgado provinces;

- Produce and distribute saplings of various fruit species in Cabo Delgado, Inhambane, Maputo and Nampula provinces;

- Promote the creation of community management nuclei at local level and support the producers in the construction of improved corrals;

- Facilitate access to mechanised cassava processing in Inhambane, Nampula and Cabo Delgado;

- Encourage the use of animal traction in Tete, Gaza and Inhambane provinces, hold livestock vaccination campaigns in all provinces, brand and register livestock in Gaza, Maputo and Tete, and keep a watch for cases of foot and mouth disease and African swine fever in Maputo province; 
- Participate in activities of the household poultry development programme in Manica province;

- Demarcate the Chirindzene reserve and undertake forestry and wild life surveys and their respective zoning in the Matibane and Mecuburi reserves;

- Draw up an Inventory of areas for forestry concessions;

- Monitor elephant migratory corridors in order to mitigate man/animal conflicts;

- Undertake radio campaigns in local languages against uncontrolled bush fires;

- Make forestry concessions operational, and implement the management plans;

- At least $10 \%$ of community companies established and operational, training of extensionists and communities in market analysis and development, and grant the community companies $20 \%$ extra seed money;

- Publicise the land legislation and procedures, gather and prepare information to update the provincial land registers, issue land titles throughout the country, and recognise new requests for land;

- Undertake consultations with local communities for the land award process;

- Identify and select the places to benefit from the installation of new irrigation schemes and/or rehabilitate the existing ones in Gaza, Niassa and Nampula provinces, and partially rehabilitate the Chipembe irrigation scheme;

- Make staff and producers aware of the danger of HIVIAIDS;

- Strengthen the organisational, technical and financial capacity of grass roots organisations.

\section{B. INFRASTRUCTURES}

\section{Roads}

Much of the activity in the area of roads will be concentrated on continuing the work defined in the Third Roads Programme, with the objective of reducing the proportion of the national road network that is impassable. This programme began in 2002 and is scheduled to end in June 2005. 
The main actions planned for the roads area are as follows:

In institutional capacity building, there will be continued efforts to strengthen the response capacity of ANE staff at central and provincial level through technical assistance to the ANE and contracting local consultants to inspect routine maintenance work on the roads.

In the development of human resources, there will be continued training and upgrading of workers in the roads area.

In the road rehabilitation and maintenance programme, there will be continued work on rehabilitating the main roads, secondary and tertiary roads, rehabilitating and assembling metallic bridges, periodic maintenance of roads and routine maintenance, as the following table summarises, which will make a $62 \%$ contribution to the evolution of the conditions of the roads.

Roads Programme

\begin{tabular}{|l|r|r|r|r|}
\hline & $\begin{array}{c}\text { Achieved } \\
\mathbf{2 0 0 3}\end{array}$ & $\begin{array}{c}\text { Forecast } \\
\text { 2004 }\end{array}$ & $\begin{array}{c}\text { Planned } \\
\mathbf{2 0 0 5}\end{array}$ & \multicolumn{1}{|c|}{$\begin{array}{c}\text { T.C.Vol. } \\
\text { 2005(\%) }\end{array}$} \\
\hline Rehabilitation of Main Roads & 63.7 & 330.0 & 221.0 & -49.3 \\
Rehabilitation of Secondary Roads & 171.4 & 188.0 & 336.0 & 78.7 \\
Rehabilitation of Tertiary Roads & 592.3 & 521.0 & 534.0 & 2.5 \\
Periodic Maintenance & 396.4 & 918.0 & 1635.0 & 78.1 \\
Routine Maintenance & 10591.6 & 13834.0 & 14343.0 & 3.7 \\
Rehabilitation and Assembly of Metallic & & 7 & 5 & \\
Bridges & & & & \\
\hline
\end{tabular}

In the rehabilitation of main roads, the programme will involve the following stretches:

\section{Rehabilitation of Main Roads}

\begin{tabular}{|l|r|}
\hline Stretch to Rehabilitate & Length in Kms \\
\hline EN1 Maputo - Marracuene & 18.0 \\
EN1 Manhiça - Incoluane & 30.0 \\
EN1 Maxixe - Crossroad EN1/ER520 & 62.0 \\
EN1 Crossroad EN1/ER 520 -Crossroad EN1/212 & 40.0 \\
EN102 Vanduzi - Changara & 16.0 \\
EN7/104/232 Namacurra - R. Ligonha & 55.0 \\
\hline TOTAL & 221.0 \\
\hline
\end{tabular}

The rehabilitation of secondary roads will follow the programme below: 


\begin{tabular}{|l|r|}
\multicolumn{2}{|c|}{ Rehabilitation of Secondary Roads } \\
\hline Stretch to Rehabilitate & Length in Kms \\
\hline EN221 Bene - Fíngoè & 36.0 \\
EN206 Chissano - Chibuto & 22.0 \\
EN223 Crossroad EN103/223 Calómue & 71.0 \\
EN239 Nametil - Crossroad EN239/260 & 49.0 \\
EN242 Litunde - Front.C.Delgado & 145.0 \\
EN256/205 Chókwe - Nova Lagoa & 13.0 \\
\hline TOTAL & 336.0 \\
\hline
\end{tabular}

Under the road maintenance component, periodic maintenance work is envisaged on about $1,635 \mathrm{Kms}$ and routine maintenance on 14,343 Kms which will be undertaken throughout the country as the table below indicates:

Road Maintenance

\begin{tabular}{|l|r|r|}
\hline Description & Periodic Maintenance & Routine Maintenance \\
\hline Rehabilitation of Main Roads & 301 & 3190 \\
Rehabilitation of Secondary Roads & & \\
Rehabilitation of Tertiary Roads & 152 & 5260 \\
& 1182 & 5893 \\
\hline TOTAL & 1635 & 14343 \\
\hline
\end{tabular}

In the area of rehabilitating bridges, there stand out the start of building the bridge over the Zambezi river at Caia, the start of work on building the bridge over the Limpopo river between Guijá and Chokwe, continued rehabilitation work on the Mozambique Island bridge, the start on building the Unity Bridge between Mozambique and Tanzania, the start on building the Moamba (Maputo province) bridge, the start on building the bridge over the Lugela river (Zambézia), rehabilitation of the bridge over the Meluli river (Nampula) and the assembly of 5 metallic bridges.

Much of the routine maintenance work will be done by labour intensive brigades employed by the ECMEP's and by other private national contractors, since technology is regarded as of great importance for the roads sector.

\section{Water and Sanitation}

In the area of water, activities will be aimed at improving the level of coverage, and the level of service provision, accompanied by institutional measures aimed at the sustainability of water supply to the rural, urban and peri-urban population.

In the area of water resource management, the following activities are planned: implementation of short term actions arising from the National Water Resource Management Strategy; viability studies for ARA-Centre-North and ARA-North; preparation of the construction projects for 10 small dams in Manica, Gaza, 
Inhambane, Sofala and Tete provinces; holding viability studies on rehabilitating the Chipembe dam, and building the Mapai dam on the Limpopo river. In the context of the weather station network, it is planned to rehabilitate 50 stations throughout the country, 30 of them measuring rainfall and 20 measuring river levels. Finally, installing a telemetric network in the Limpopo basin is planned.

As for water sharing agreements, stress should be laid on the following:

INCOMAPUTO - Interim tripartite agreement between Mozambique, South Africa and Swaziland for cooperation in the protection and sustainable use of the water resources of the Incomati and Maputo river basins. Under this agreement, through the Tripartite Technical Committee (TPTC) between South Africa, Mozambique and Swaziland, it is intended to promote implementation of the INCOMAPUTO Joint Plan of Action, and ensure implementation at internal level through coordination and regular follow-up of activities with the relevant national institutions.

LIMPCOM - Agreement between Mozambique, South Africa, Botswana and Zimbabwe on establishing the Limpopo River Basin Commission, under which it is intended to promote implementation of the agreement at national and international level, through preparing draft plans and activities for LIMPCOM to take effect, and developing mechanisms for complying with the obligations arising from signing the agreement creating LIMPCOM in coordination with the institutions involved in the management and use of the water resources of the Limpopo Basin.

ZAMCOM - Agreement between Mozambique, Angola, Botswana, Malawi, Namibia, Tanzania, Zambia and Zimbabwe on establishing the Zambezi River Basin Commission, under which it is intended to promote implementation of the agreement at national and international level through drawing up draft plans and activities for ZAMCOM to take effect.

Under the Rural Water Supply Programme, continued activities are planned to rehabilitate and to build scattered sources to increase coverage, and to build, rehabilitate and extend Small Water Supply Systems that will serve towns and district capitals. Thus, studies will begin to draw up Executive Projects for the rehabilitation and expansion of systems in Niassa, Nampula and Tete provinces, studies will be concluded for systems in Cabo Delgado and Nampula provinces, and, as regards implementation of the work, emphasis should be laid on the start of work on systems in Cabo Delgado, Tete, Manica, Inhambane and Maputo provinces. The target for rural water coverage for 2005 is $46.5 \%$. The construction and rehabilitation of 2,310 sources is planned, thus raising the percentage of the population with access to rural water to $46 \%$. 
Rehabilitation and Construction of Water Sources

\begin{tabular}{|r|r|r|r|r|}
\hline Province & \multicolumn{2}{|c|}{ Construction } & Rehabilitation & \multicolumn{1}{c|}{$\begin{array}{c}\text { Total } \\
\text { Sources }\end{array}$} \\
\cline { 2 - 4 } & $\begin{array}{c}\text { Mechanical } \\
\text { boreholes }\end{array}$ & Wells & $\begin{array}{c}\text { Boreholes } \\
\text { and Wells }\end{array}$ & 183 \\
\hline C. Delgado & 50 & 23 & 110 & 225 \\
Niassa & 55 & 50 & 120 & 625 \\
Nampula & 180 & 90 & 380 & 440 \\
Zambézia & 170 & 80 & 190 & 152 \\
Tete & 42 & 25 & 85 & 85 \\
Manica & 30 & 5 & 50 & 65 \\
Sofala & 30 & 35 & 25 & 330 \\
Inhambane & 115 & 40 & 140 & 90 \\
Gaza & 25 & 10 & 55 & 115 \\
Maputo & 25 & 10 & 80 & 2310 \\
\hline Total & 722 & 368 & 1235 & \\
\hline
\end{tabular}

The target for urban water supply is to guarantee that $40 \%$ of the urban population has access to clean drinking water. 28,000 new connections are planned. Under the 5 cities projects, the following are projected: Maputo City continue work on building the Hulene Distribution Centre, and its distribution network, and the expansion of the system to neighbourhoods in the northeastern part of Maputo; Beira - continue work on building the new impoundment station on the Pungue River, to guarantee improved quality and greater quantity of water; Quelimane - start of work on building the new water supply system, and building the new reserve system in Nicoadala and Quelimane; Nampula rehabilitation work on the old treatment station in order to double the existing treatment capacity, and expand the network, covering new areas and improving services.

In the sanitation area, special attention will be paid to actions that seek to reduce mortality from water borne diseases, and to promote hygiene and public health through introducing an approach integrating water and sanitation.

In order to improve the urban sanitation system, it is planned to start rehabilitating the Maputo, Matola and Beira systems.

As for water supply and sanitation, particular attention will be paid to continuing the 4 cities project (Inhambane, Maxixe, Xai-Xai and Chókwe) in its 2nd phase, construction of latrines in low-lying areas and monitoring the results, building of solid waste decomposition units, and improving the sanitation systems in the 4 cities.

The urban sanitation target is to guarantee that $37 \%$ of the urban and peri-urban population has access to sanitation services. The building of 25,000 improved latrines is planned. As for rural sanitation, the construction and improvement of 13,000 latrines is envisaged, thus raising the percentage of the rural population with access to sanitation services to $37.6 \%$. 


\section{Institutional Development}

Some reforms will be introduced in the implementation of the National Water Policy in order to improve the sector's performance. In this area, the following should be mentioned:

- Continuation of the process to set up the nuclei of the Centre-North and North ARAs, and consolidation of the Centre and Zambezi ARAs;

- Continued implementation of the demand principle in water supply to rural areas;

- Improve the performance of monitoring systems, particularly with regard to gathering water supply and sanitation coverage data. To improve the monitoring system, it will be necessary to strengthen institutional monitoring capacity, mainly at provincial level;

- Implement the Water Sector Human Resource Management and Development Strategy;

- Continue drawing up the Water Resource Integrated Management Strategy, and proceed to revise the Water Law;

- Continue decentralised planning and implement the Water Sector Human Resource Management Strategy in order to strengthen capacity, particularly at provincial level;

- Approve and test the models of the National System for the Management of Small Systems in 3 systems by the end of 2006;

- Consultative process for the strategy and action plan for promoting small and medium rural water and sanitation companies, including the future of EPARs and the implementation of pilot activities that will be carried out in at least 3 provinces in 2005 and in the rest by the end of 2008;

- Approval of the total allocation from the decentralised sector budget for wells and boreholes;

- With regards to the introduction of SWAP within the water sector programme, the start of long term planning and an ever greater adherence by partners are envisaged;

- Start implementing the regulations on Licences and Concessions, and the draft statutes for the creation of CEDESA (Centre of Studies for Water Sector Strategic Developments).

In order to guarantee increased access to energy for domestic use and for economic activities, actions will be undertaken to expand the national electricity grid, and the network for the distribution and sale of liquid fuels, as well as actions seeking to implement identified energy projects and reforms in the sector. Thus the actions to be undertaken are: 
- Continue expanding the national electricity grid to connect the following places: (Nampula) - Moma, Netia, Nacaroa, Chalaua, Murrupula and Muecate; (Cabo Delgado) - Montepuéz, Chiúre, Namapa, Ancuabe and Metoro; (Niassa) - Lichinga and Metangula; (Zambézia) - Namacurra, Maquivale, Zalala, Macuse, Maganja da Costa and Inhassunge; (Tete) Chitima, Chicoa, Mágoè, Mukumbura, Chipanga, Murraça and Changara; (Manica) - Catandica, Guro, Inhazoia, Cruz and Macossa; (Sofala) Micane, Caia, Inhamitanda, Inhaminga, Marromeu, Nhansacara and Missana; (Inhambane) - Zandamela, Chissibuca, Mavila, Cambine, Morrumbene, Massinga and Murrungulo; (Gaza) - Limpopo Valley and Massingir;

- Electrification based on solar powered systems of the following localities: (Tete) - Boroma, Doa and Domue; (Manica) - Mungari and Mavonde; (Sofala) - Muxungue and Estaquinha, (Inhambane) - Vila Franca do Save;

- Continue implementing the project to build the Switching Centre, which will allow centralised management of the National Transmission Network, and better coordination with the regional energy transmission system within the Southern Africa Power Pool;

- Continue actions seeking to implement energy projects under the Memorandum of Understanding between Mozambique and South Africa about the NMPD (North Mozambique Power Development Initiative);

- Conclude the viability study on the Massingir hydro-electric project;

- Continue reforms in the energy sector, including the promotion of private participation in a concession regime;

- Develop incentive mechanisms to expand the distribution and sales network for liquid fuels, particularly to rural areas, and for kerosene and LPG, as well as ensuring the supply of unleaded petrol nationally;

\section{FISHERIES}

In this sector, the activities to be undertaken will be aimed at improving domestic supplies of fisheries produce, through increasing the amount landed, and reducing post-catch losses, growth in exports through increasing the amount produced by fish farming and adding value to artisanal production, and improving the living conditions of fishing communities. Thus, the actions to be undertaken are:

In the area of artisanal fishing: 
- Development of conditions for adding value to artisanal fishing production through the extension of improved processing techniques and conservation mechanisms as well as promoting measures to collect and market production with the involvement of private operators;

- Increasing the economic yield of the fishermen through the extension and modernisation of fishing techniques for operations on the open sea, and diversification of production;

- Study mechanism for mass collection and use of the by-catch from industrial prawn trawling, with the involvement of artisanal operators;

- Continue action to improve the living conditions of the fishing communities through support for building schools, health centres and water sources, and for the rehabilitation of tertiary access routes in Zambézia, Sofala and Nampula provinces, under the Integrated Sofala Bank Artisanal Fisheries Project;

- Conclude treatment of the data from the national artisanal fisheries census, and harmonise the results within the National Statistical System in coordination with the INE;

- Continue micro-credit activities in the areas covered and expand them to new areas where fishing can be encouraged;

- Hold training seminars and sessions for associations of fishermen with priority for areas where integrated projects are implanted, and in promoting the training of community councils and co-management district forums in Cabo Delgado, Nampula, Sofala and Zambézia provinces.

In the area of semi-industrial and industrial fisheries:

- Undertake research and experimental activities in new fishing areas;

- Improve capacity to inspect fisheries activity and to control fishing efforts in order to ensure sustainable fisheries;

- Hold bio-economic studies of the prawn fishery;

- Introduce fishing equipment that is compatible with protecting turtles while trawling, and adopting combined measures to reduce the by-catch (fish) caught during prawn trawling, and to maximise the economic use made of the by-catch that is caught;

In the area of Fish Farming and Fisheries Research:

- Continue to promote the development of sustainable farming of prawns and seaweed, in order to increase exports; 
- Continue support for initiatives to develop fish farming in inland areas to guarantee increased production of fish for consumption and of a surplus for export;

- Continue promoting conditions whereby fish farming produce can enjoy access to export markets, through inspecting hygienic and sanitary conditions on the fish farms, and audits of the quality control systems;

- Expand the micro-credit system to promote artisanal fish farming;

- Monitor and evaluate the state of exports of the resources of surface water and deep water prawns, and fish (including Kapenta from Cahora Bassa) in order to support management measures;

- Consolidate application of the sampling system in the artisanal fisheries statistics, with a view to expanding the sample, and designing a method of extrapolating from the results;

- Assess the potential for developing marine and fresh water fish farming.

With regard to public administration, infrastructures and fisheries equipment:

- Continue revising and drafting the general and specific regulations of the Fisheries Law, particularly the Regulations for Inland Waters Fisheries;

- Continue the financial clean-up and restructuring of the state business sector, namely Emopesca and the fishing ports;

- Continue implementing the Monitoring, Control and Inspection System $(\mathrm{MCV})$, with stress on inspection via satellite (VMS);

- Draft the sector's Statistical Master Plan, and finish developing the Methodology for Planning and Monitoring activities of the fisheries sector in the framework of the National Statistical System;

- Start the project to rehabilitate Beira Fishing Port, and build installations for the Cabo Delgado Provincial Fisheries Services;

- Rehabilitate the premises of the Fisheries School, and of the Small Scale Fisheries Development Institute;

- Design the project to build new premises for the Ministry of Fisheries and study the project to rehabilitate the Angoche Fishing Port.

\section{MINERAL RESOURCES}

In this sector, in 2005 activities will be centred on increasing production and exports, through stimulating mining, and making electricity available. Among the main activities to be undertaken the following stand out: 
In the mining sector:

- Continue activities seeking to develop the heavy sands projects at Moma, Chibuto and Moebase, as well as promoting the licensing of new areas for prospection and mining research;

- Establish mechanisms for incentives for increased production, processing and primary transformation of mineral products such as tantalum, graphite, diatomite, granite, titanium, industrial beryl, among others;

- Implement a fiscal regime more attractive to investment;

- Promote small scale and artisanal mining, as well as the exploitation of deposits of apatites and phosphates with a view to setting up a fertiliser industry in the country;

- Promote the extraction and processing in an organised way of precious and semi-precious stones, in order to formalise this sector throughout the country, through associations;

- Continue consolidating the pilot centres for small scale mining in Zambézia, Tete and Nampula;

- Guarantee implementation on the ground of the Moatize Coal Project, and the signing of agreements under the technical and economic viability study to be presented by the company granted the concession;

- Promote the licensing of coal research in other coal basins.

In the geological sector, attentions will be directed to:

- Continuing the geological inventory and mapping under the Capacity Building and Reform Project in the Mining Geology Sector;

- Promote and follow the prospection for heavy minerals in potential sands along the coastal strip from Quelimane to Quinga in Zambézia and Nampula provinces, respectively;

- Draw up the new geological map of Mozambique on the scale of 1:1.000.000 and guarantee continued prospection and research in selected areas on the scale of 1:50.000;

- Start the environmental geological mapping of the Mozambican coastal zone on the scale of 1:50.000 and draw up the Engineering Geology Map of Maputo on the scale of 1:50.000;

- Promote the inventory of non-metallic minerals in Maputo, Gaza and Inhambane and the inventory of the country's mineral and thermal waters;

- Conclude the geological mapping of the entire national territory on the scale of 1:250.000, and continue establishing the National Geological Museum; 
- Guarantee the expansion, upgrading and maintenance of the seismographic stations throughout the country.

As for the hydrocarbon sector, measures for 2005 are:

- Guarantee continued and systematic prospection for hydrocarbons in the Moçambique and Rovuma basins;

- Guarantee prospection activities in the Rovuma basin, in the Zambezi offshore blocks, in blocks 16 and 19, and in other onshore and offshore blocks;

- Ensure additional prospection in the Pande and Temane blocks, including opening research and production wells so as to increase the reserves and maximise use of the gas resources of these blocks;

- Ensure conclusion of the study on options for processing inside the country and of transporting condensed gas from Pande and Temane, including the possibility of building a quay specifically for transport and sale on the domestic and foreign markets;

- Guarantee conclusion of the studies assessing the Inhassoro deposit, which may make its commercial exploitation possible;

- Guarantee conclusion of the studies for the use and distribution of natural gas at the five offtake points along the gas pipeline between Temane and Ressano Garcia to implement projects aimed at the industrial and domestic sectors;

- Ensure expansion of the Data Centre, so as to make it a national and international reference point providing assistance to companies interested in investing in the petroleum sector;

- Consolidate the legal framework for the sector, and set up the National Petroleum Institute;

- Monitor the production of natural gas at Temane, and its export to South Africa;

- Promote the licensing of new areas for hydrocarbon prospection;

- Ensure the conclusion of the pipeline from Ressano Garcia to Matola, for the supply of natural gas.

As for the inspection sub-sector, the measures for 2005 are:

- Continue monitoring and inspection of geological, mining and hydrocarbon activities in order to ensure compliance with the legislation in force;

- Ensure legality, regularity and good management of acts and procedures in the budgetary and patrimonial areas of the sector; 
- Control the legality of the procedures and operation of the administrative services of the sector.

\section{E. INDUSTRY AND TRADE}

In this sector, the specific objectives for 2005 are to regulate competition, integrate the informal sector into the formal system, ensure permanent access to international sources of information on prices, market trends and national statistics, and improve the quality and competitiveness of Mozambican products and services. The main actions planned for 2005 are:

- Reformulate industrial policy and strategy;

- Draw up and implement strategies for the textile and clothing, and metalworking sectors;

- Draw up and implement the Strategy for Small and Medium Companies (PME`s);

- Implement the Strategy for developing Exports of Wood Produce processed in Mozambique;

- Draft the Competition Policy;

- Draw up and implement the Agricultural Marketing Strategy (ECA) for the period 2005/2009;

- Participate in joint missions: Government, FAO and WFP;

- Simplify and computerise commercial and industrial licensing;

- Publicise the Regulation on Commercial Licensing;

- Restructure the ICM;

- Ensure the country's participation and representation in bilateral, regional and multilateral trade systems;

- Step up bilateral trade relations, particularly with neighbouring countries;

- Guarantee inspection of industrial and commercial activities;

- Implement and monitor the Quality Policy and Strategy, and also support economic associations and the productive sectors in quality matters so as to make them more competitive;

- Guarantee the restructuring of the Small Scale Industry Fund (FFPI);

- Expand implementation of single counters for attending to the public. 


\section{F. TOURISM}

In this sector, activities will be centred on continuing and complementing actions that have already begun. Taking into account the existing opportunities from the perspective of growing evolution of the sector, of tourist activity and of the promotion of the sustainable development of tourism and of its fundamental role in poverty reduction through job creation, and its contribution towards attenuating imbalances in regional development, the following are planned for 2005 :

In the institutional field

- Disseminate the Tourism Policy and the Strategic Plan nationally, from the perspective of mobilising funding for the activities included in the Strategic Plan for the Development of Tourism in Mozambique;

- Set up a National Tourism Forum with the purpose of establishing a platform for consultation between those involved in the development of tourism;

- Continue assessing the institutional structure of the Ministry of Tourism, and make it adequate for responding to the needs of the industry;

\section{Human resources}

- Continue activities to stimulate mid-level training in the area of the hotel industry, tourism and conservation;

- Approve the Human Resource Strategy for the tourism sector;

- Develop a mechanism for the career placement of wardens allocated to the conservation areas;

- Encourage private sector participation in providing training, education and professional skills in the tourism sector;

- Revive the training centre at the Gorongosa National Park, and the basic training school for game wardens at the Maputo Special Reserve;

- Develop training and upgrading programmes for tourism inspectors;

- Reorient the Andalucia Hotel-School.

Inter-sector Coordination, Inspection of Tourism and of Private Investment:

- Regulate the Tourism Law;

- Revise the classification of hotel establishments;

- Implant the Chimanimani Reserve management structure, and re-occupy the Pomene and Gilé reserves; 
- Encourage the creation of inter-sector coordination platforms at various levels;

- Continue with inspections in tourist zones, and supervision in he conservation areas;

- Promote growing participation by Mozambican investors in tourism through strengthening the FUTUR programme, and

- Develop a strategy to support small and medium companies in the tourism sector, and mobilise investment for the Conservation Areas.

\section{Conservation areas}

- Consolidate the development of the Libombo, Limpopo and Chimanimani cross-border conservation areas, by mobilising public and private investment;

- Adopt measures for the economic use, and develop systems to monitor and evaluate the development of the conservation areas, namely the Quirimbas Park, Gorongosa, Limpopo and Chimanimani;

- Design guiding standards for the establishment of administrative and recreational infrastructures, reorganise the management structure, and develop a corps of wardens in the conservation areas;

- Continue actions to rescale the hunting areas;

- Start establishing new cross-border conservation areas, namely: ZIMOZA and Niassa/Cabo Delgado.

\section{Tourist promotion}

- Develop mechanisms to make use of the services provided by Mozambique's representations abroad to promote tourism;

- Approve the Marketing Strategy;

- Continue setting up information counters for travellers at the main crossing points;

- Continue actions to encourage domestic tourism;

- Explore the possibilities for strategic alliances with neighbouring countries to participate in international tourism fairs;

- Install/develop a Portal for "Tourism in Mozambique";

- Develop a public relations programme and promote awareness programmes for the various sectors that deal with tourists; 
- Hold in Mozambique the Congress of Travel Agencies, which involves thousands of economic agents and media professionals, and which serves as a vehicle for increasing the number of tourists and revenue in coming years, as well as placing the country on the international tourist market;

- Work in partnership with other sectors to consolidate the programme of cultural and events tourism.

\section{G. TRANSPORT AND COMMUNICATIONS}

In this sector, the actions planned for 2005 will continue to be marked by a gradual improvement in the reliability, safety, comfort and expansion of transport services provided to the public in urban and rural areas, in more efficient participation by the national business class in control, operation and investment in the sub-sectors, and the rapid development of the sector through updating legislation, adapting it to the changes/demands that are taking place, making it more inclusive and dynamic. Thus in 2005 the following will be undertaken:

\section{In the area of Communications}

- Telecommunications Policy drafted and approved by the Council of Ministers;

- Draft the Policy on Universal Access;

- Draw up the Strategy for Developing Universal Access;

- Draw up the Postal Sector Policy;

- Draw up the Postal Service Law;

- Develop the Strategy for Restructuring the Postal Sector; and

- Privatise TDM.

In the area of Civil Aviation

- Develop Nacala International Airport;

- Continue actions to improve conditions of air safety and navigation.

In the area of Maritime, River and Lake Transport

- Hydrographic surveys in the ports of Maputo, Beira, Inhambane, Quelimane, Bazaruto and Mocímboa da Praia/Chinde;

- Hydrographic surveys in Niassa (ICEIDA Project);

- Production of sailing directions for southern Mozambique and Lake Niassa; 
- Build the lighthouse at the approach to the port of Chinde;

- Rehabilitate the Mafamede lighthouse, in Angoche;

- Maintain the network of navigation aids;

- Study the general circulation in the bays of Maputo and Sofala;

- Study the distribution of pollutants within Maputo bay;

- Rehabilitate docking infrastructure particularly for the Maputo/Catembe and Inhambane/Maxixe ferries;

- Acquire vessels for the crossings.

In the area of Road Transport

- Revise the Automobile Transport Regulations (RTA);

- Set up road terminals along the main transport corridors, with priority for the cities of Maputo, Beira, Nampula and Tete;

- Reorganise the road traffic inspection system, in order to combat illegal exercise of this activity;

- Encourage expansion of the freight transport network into rural areas, in order to support peasants in marketing agricultural surpluses;

- Redefine the policy of technical assistance for automobiles;

- Consolidate the operations of the road transport management subcommittees to monitor and implement bilateral and multilateral agreements;

- Review the bilateral road transport agreements.

\section{In the area of Road Safety}

- Continue actions to improve road safety conditions;

- Make compulsory insurance operational;

- Introduce road inspection and supervision;

- Set up a system of information and harmonisation of norms and procedures in the context of SADC.

\section{In the area of Ports and Railways}

- Continue actions aimed at leasing out the Nacala port and railway, and

- Continue actions aimed at leasing out the port of Quelimane, as well as mobilising funds for dredging the port of Beira. 


\section{In the area of Meteorology}

- Continue actions to improve the quality of weather forecasts, through the introduction of numerical models; and

- Continue actions to improve the system for communicating meteorological information to the public through the publication of weather forecasts on television, the Internet, audiotext and newspapers in a format easier to understand.

\section{V.3. GOOD GOVERNANCE, LEGALITY AND JUSTICE, DECENTRALISATION AND DECONCENTRATION}

Good governance is one of the fundamental conditions for a successful strategy of fighting poverty. PARPA includes policies to promote good governance, such as: decentralisation and deconcentration, reform of the public administration so that it responds better to the needs of citizens, the strengthening of the capacity and efficiency of the legal and judicial system, improvements in public security, and the development of a programme focused on reducing corruption at all levels.

\section{A. REFORM OF THE PUBLIC SECTOR, DECENTRALISATION AND DECONCENTRATION}

The reform of the public sector covers components of decentralisation and rationalisation of structures and procedures of service provision, improved formulation and monitoring of public policies, professionalisation of the staff in the Public Sector, improved financial management and accountability, and the fight against corruption.

In decentralisation and deconcentration, PARPA establishes as the main objective endowing the Local State Bodies at district and provincial level with greater dynamism and capacity. Thus, among other actions to be developed to this end, the following deserve mention:

- Monitor implementation of Law $n^{\circ} 8 / 2003$ on Local State Bodies and its Regulations, in training and upgrading civil servants, taking the following aspects into account: institutional reform, rationalisation of human resource management, rationalisation of administrative procedures and assistance to the Local State and Local Authority Bodies;

- Clarify information on the budgetary transfers in the Budget Execution Report for the municipalities (FCA and FIIL); 
- Monitor district performance in participatory planning, based on the Participation Guide;

- Investigate options for increasing allocations of Local Development funds to the districts through clear criteria of intergovernmental transfer using a basic formula, and establish targets for 2006-2007;

- As for the transfer of allocations from the Finance Ministry and the Sectors to the Districts for capital expenditure: clarify the functionality of SISTAFE for integrated district planning and for accountability at district level;

- Conclude the Regulations for the Local Authority package of laws;

- Continue building and rehabilitating the infrastructures of District, Administrative Post and Locality Administrations;

- Extension of District Development Plans to 53 districts and undertake the placing of street names in 27 municipalities;

In the context of rationalising their structures and providing services, all the ministries (Health, Education, Agriculture, State Administration, Industry and Trade, and Finance) are undertaking functional analyses, For 2005, it is envisaged that restructuring plans already submitted to UTRESP will be approved and a start will be made on implementing them. But some challenges remain, related with the need to ensure a detailed analysis and dialogue based on identifying the problem and drawing up concrete recommendations for the restructuring phase.

As regards the professionalisation of the civil service, and administrative modernisation in order to attain the final goal of improving the quality of services provided to citizens, the following activities shall be undertaken:

- Study of the wage policy, in which it will be important to ensure agreement on wage policy and implementation of related activities such as the integration of data bases with different forms of payment, concluded in accordance with the target and appropriate advice;

- Make the SIP operational in a network between MAE, MF and the TA;

- Draw up the National Policy for Managing State Documents, Records, and Archives;

- Continue studies to allow identification of services that the state could provide electronically;

- Start implanting the Single Counter (concentrated units of public services) in the cities of Maputo, Beira and Nampula;

- Adopt the Mozambican Civil Service Charter;

- Approve the General Statute of State Functionaries; 
- Set up the Higher Institute of Public Administration (IISAP);

- Undertake studies aiming at the gradual introduction of e-government; and

- Translate the explanatory text of Decree $n^{\circ} .15 / 2000$, of 20 June, about the Community Authorities.

In the monitoring and evaluation of PARPA, the main objective of which is to harmonise the medium and short term instruments to guarantee proper integration between PES, PARPA and the CFMP, efforts in 2005 will remain concentrated on revising PARPA. This should be undertaken through a consultative process, and incorporating cross-cutting issues, including HIVIAIDS and gender. Thus the greatest priority will go to the following actions:

- Inclusion of the indicators from the PAF/PES matrix in the reports on the Balance Sheet of the PES;

- The revision of PARPA;

- Integration of the cross-cutting issues (gender, HIV/AIDS and others) in the PARPA process which should be consultative;

- Hold a study on the social impact, and impact on poverty of the land tenure regulations. This is in line with the letter of intent between the Government of Mozambique and the IMF;

- Monitor the impact of district planning and financing in relation to the PARPA objectives in some districts, results from which will be published in 2006;

- Mainstreaming of gender into planning and monitoring;

- Greater harmonisation of support, including technical assistance on Monitoring and Evaluation.

In the area of improving financial management and accountability, stress will be laid on the implementation of e-SISTAFE, on programme budgeting, on the reform of state procurement, tax reform and the strengthening of internal and external audits.

With regard to strengthening the systems of financial and budgetary planning, one should mention strengthened management of reform, and identification of realistic objectives in the implementation of e-SISTAFE and the selection of an indicator for effective anti-poverty budgeting and budgetary execution, including provinces and districts that will be analysed in 2005 as part of PARPA II, to be introduced in 2006, conclusion of the Budgetary Execution Report for the first quarter through e-SISTAFE and publication on the Internet.

In tax reform in 2005, it is planned to approve the regulations and procedures of the Tax Authority of Mozambique (ATM), progress in processing VAT 
reimbursements, achieving the revenue targets, and strengthening the functions of the tax administration through the computerised system.

With regard to Procurement, in order to adopt a transparent and efficient system, in 2005 it is planned to implement a modern procurement system in line with best international practices, based on the new procurement regulations, and linked up with e-SISTAFE.

In terms of strengthening internal and external audits, the government will start a constructive dialogue with the Administrative Tribunal, so that the two may jointly define an indicator before the end of 2004 to monitor progress in external audit activities and drafting strict monitoring of the follow-up for implementing recommendations of the priority components of the strategic internal audit strategy, which is an important factor in the work of the IGF.

The need to develop an Assessment of Fiduciary Risk as a credible instrument for monitoring management of public finances, including implementation in 2005 of follow-up measures agreed during the workshop held in November 2004.

In drawing up the strategy for implementation of the IAS, a study will be held to understand the implications of the IAS on fiscal policies and regulations, supervise the insurance sector using the new plan of accounts, and prepare the study on transition to the IAS. Develop and implement a plan for restructuring EMOSE. Prepare regulations on complementary (private) pensions, and revise the Law on Social Protection.

To strengthen the institutional capacity of the Bank of Mozambique and other regulatory authorities, for 2005 the issuing and implementation of the LICSF regulations are planned. In the area of micro-finances, it is envisaged that regulations on micro-finance will be implemented, with attention paid to sustainability, and the finalisation and implementation of the strategy to regulate investment by public companies. The insurance sector will also be improved and the social protection system strengthened. It is planned to submit to parliament the bill on social protection, and to begin the actuarial study on the social security system.

In the area of Good Governance and the Fight against Corruption, it is planned to draw up and approve the anti-corruption strategy, and begin implementing it based on the data from the National Research on Governance and Corruption (analytical report of the research).

Publication of the first study, which is related with the survey on corruption in the justice system, and identification of the other institutions to be covered by the study. 
Efforts will also be made to reactivate the State Administrative Inspectorate (IAE).

In the sphere of Justice in 2005, efforts will continue to be made to implement the Integrated Strategic Plan, with the aim of simplifying procedures and increasing efficiency in the provision of services by the judicial system. By components, the main actions are:

Strategy for Inter-Institutional Development and Communication

- Institutionalise the Legality and Justice Coordinating Council;

- Conclude the vision document and the ensuing revision of the PEI and POPEl;

- Draw up a harmonised Monitoring and Evaluation system;

- Hold a training seminar in Maputo for 50 staff of the Ministry of Justice on questions of statistics, planning and monitoring;

- Make technical support visits on planning and monitoring to the provinces.

\section{Strategy on Access to Justice}

- Establish the conditions for the community courts to operate;

- Entry into operation of Commercial Sections in the Maputo City Law Court: Creation of two more sections to settle commercial questions;

- Hold a seminar to harmonise the creation of dispute settlement mechanisms;

- Draw up and distribute 1,000 copies of a brochure on Human Rights in the southern, central and northern zones. Hold 3 sessions on human rights for 1,000 people in districts to be selected;

- Development plan for the areas of administrative and customs disputes, including the reorganisation of registry offices, rules and procedures;

- Increase efficiency in the provision of services by the judicial system, through:

o Increasing the number of verdicts by $42 \%$ in comparison with 2002 ;

0 Reducing the number of prisoners awaiting charge and trial, so that a maximum of $57 \%$ of prisoners are awaiting trial.

\section{Training Strategy}

- Initial training of 14 Judges, 7 Prosecutors, 5 Registrars, and 5 Notaries;

- Training of 60 Law Officers and 5 Judicial Assistants; 
- Complementary training of 10 judges and 10 prosecutors;

- Training of 10 judges and 3 prosecutors in commercial matters;

- Establishment of a Professional Institute of Auditors for the bodies of internal and external control - viability study.

\section{Legal Reform Strategy}

- Draft reform of the Civil Procedural Code;

- Draft reform of the Inheritance Law;

- Draft reform of the Notarial Code;

- Draft reform of the Organic Law on Law Courts;

- Draft Organic Law on Community Courts;

- Draft Organic Law on IPAJ;

- Draft Organic Law on the Administrative Tribunal;

- Concluding the draft law on prison organisation;

- Draw up a revision of the Real Estate Registration Code (seeking to improve the financial environment);

- Draw up a revision of the Automobile Registration Code (seeking to improve the financial environment);

- Draft the Code on Bankruptcies and Recovery of Companies (seeking to improve the financial environment);

- Concluding the draft Organic Law on the Prison Guards of Mozambique;

- Law on Protecting Children;

- Law on Trafficking in Migrants;

- Drawing up a bill on Trafficking in People, particularly Women and Children.

- Drawing up a bill on Trafficking in Arms, their components, and ammunition;

- Concluding the bill on Extradition and International Cooperation and delivering it to CIREL;

- Drafting a bill on organised, cross-border crime;

- Drafting a bill on terrorism.

\section{Infrastructure and Equipment Strategy}

- Continue building open Prison Centres through the pilot self-build project; 
- Continue building the Beira and Xai-Xai prisons;

- Start the construction of new buildings for the Attorney-General's Office and for the Law Courts in Inhambane, Zambézia, Maputo and Niassa provinces and Maputo City;

- Continue rehabilitating the Maputo Central Prison and the penitentiaries of Mabalane, Nampula and Manica;

- Conclude building the registry office in Mopeia (Zambézia);

- Acquire and distribute to the prisons 30 television and video sets for use by the inmates;

- Undertake a diagnostic study on the costs of rehabilitating the main prisons;

- Undertake a classified inventory of the assets of the Prison System.

\section{Legal Documentation Strategy}

- Project to Reproduce the Codes - CP, CPP, CC, CPC, and CE;

- Acquire 50 copies of the main legislation on the civil service and distribute them to the sectors of the Ministry of Justice.

\section{Modernisation and Computerisation Strategy}

- Design and start establishing software for information on prisoners and for the registry and notarial offices.

\section{Human Resource Strategy}

- Recruit and select so that that the staff table of the provincial law courts is $90 \%$ complete by the end of 2005 ;

- System of inspection and control of the Ministry of Justice human resources. Hold a training course for National and Provincial Directors on performance control and career progression;

- Recruitment of 20 magistrates with university degrees.

Control of legality

- Select investigators and inspection staff for the Public Prosecutor's Office;

- Select investigators, magistrates, experts and staff for the Central AntiCorruption Office;

- Regulations and decree on inspection. 
Other actions in the justice sector

- Undertake a diagnostic study on the HIVIAIDS situation in the prisons;

- Produce educational material on HIVIAIDS for prisoners;

- Hold sessions on HIVIAIDS for prisoners.

In the sphere of Public Order, one of the priority objectives is to improve the capacity of the Police to prevent and pursue crime. In 2005, the following actions will be undertaken:

- Strengthen and guarantee the protection and security of people and property;

- Expand the Community Policing programme;

- Build the following premises: Civil Identification Directorate of Inhambane, District Police Command of Muembe, Fire Brigade command in Tete, District Police Command of Nicoadala, District Police Command of Mossuril, Building of DIC - Cabo Delgado, and District Police Command of Meluco;

- Rehabilitation of the Matalane Centre, the Maputo City PIC building, the Nampula PIC Laboratory, the Maputo Civil Prison, the Top Security Prison (BO), the Tete provincial immigration services, and the Sofala DIC building;

- Introduction of biometric passports.

\section{V.4. FOREIGN RELATIONS AND DEFENCE}

In the area of Foreign Relations, the government will pursue and increase privileged relations with all Mozambique's development partners, in order to make its plans and programmes operational, publicising the country's potential, mobilising means and resources to carry out the government's Five Year Programme, and to eradicate absolute poverty, and strengthening the prestige and standing of Mozambique in the international arena.

Thus the government will undertake activities that seek to strengthen existing relations of friendship and cooperation and give fresh impulse to the joint cooperation commissions and the annual consultations with other countries. Likewise, the government will continue to widen the universe of partnerships with other countries and organisations in order to implement the 2005 Economic and Social Plan.

Thus the government will: 
- Prepare and organise official and working visits abroad by the Head of State, to strengthen bilateral cooperation;

- Organise participation by the Head of State at Summits, Conferences and other relevant events;

- Hold working and official visits and participation in international conferences by the Minister of Foreign Affairs and Cooperation and other government members;

- Analyse the government's diplomatic activity, draw up perspectives for future activity and rationalise diplomatic and consular representation abroad, so as to make these representations better able to perform their duties;

- Study the practice of multiple accreditation for greater presence and diplomatic coverage;

- Continue to negotiate with partners for the total forgiveness of Mozambique's foreign debt, both in the context of the Club of Paris, and through bilateral understandings with other countries that are not members of this group;

- Undertake activities in the areas of negotiation, conclusion and ratification of international conventions and treaties, bilateral agreements and their consequent incorporation into the national legal order;

- Disseminate information about business opportunities in Mozambique;

- Speed up identification and implementation of the priority national, subregional and regional development programmes and projects, in the context of NEPAD;

- Ensure implementation of SADC protocols, particularly the Trade Protocol, and facilitate the free circulation of people;

- Look after the defence of national interests in the framework of negotiating Economic Partnership Agreements (EPAs) between SADC and the European Union, seeking to strengthen regional integration and consequent integration into the world economy;

- Participate in the negotiations on the multilateral trade system, through the World Trade Organisation;

- Continue monitoring and evaluating projects financed by cooperation partners, through visits to the provinces;

- Continue working to assist Mozambican communities in the diaspora, and promoting their involvement in the country's political, economic and social life; 
- Continue negotiations on demarcating the maritime border, and reaffirming the land borders with the neighbouring countries;

- Draw up the draft Cooperation Policy of the Republic of Mozambique.

In the area of Disaster Management, the government will:

- Readjust the National Disaster Management Plan, and strengthen mechanisms for coordination and response to disasters among the countries of southern Africa;

- Mobilise resources for the prevention and mitigation of disasters;

- Map areas at risk of disasters;

- Step up training activities and civic education among the people vulnerable to disasters;

- Strengthen the resources allocated to the disaster early warning system;

- Sign regional agreements on mutual assistance in the event of disasters.

In the area of Demining, the government will:

- Hold, in coordination with the donors, the annual meeting with the demining operators, with the participation of the provincial governments and other stakeholders in demining, seeking to draw up strategies for the activity of the IND;

- Continue the study on the socio-economic impact of demining in Mozambique.

In the area of support for refugees, it is intended to set up INAR representation in Cabo Delgado, Nampula and Tete.

In the area of Defence, the following activities will be undertaken in 2005:

- Approve the package of complementary legal diplomas, particularly the Strategic National Defence Concept, the Equipment and Weaponry Policy, the draft amendments to the Law on Military Service and its respective Regulation, the draft revision of the Military Fee, and the bill on Honours and Decorations;

- Establish, maintain and expand the conditions for access by citizens to military service;

- Raise the capacity and combat readiness of the Mozambican Armed Forces for the defence of the country, and compliance with peace-keeping missions;

- Continue participation in peace-keeping missions, particularly in the Democratic Republic of Congo, Timor, Burundi and Sudan; 
- Guarantee that FADM officers will be sent to courses on peace-keeping and for military observers;

- Continue to ensure the FADM's participation in efforts at cooperation and regional integration, at continental and international level, as regards the harmonisation of defence and security mechanisms;

- Gradually reduce external dependence in the training of military technical staff;

- Implement the new Organic Diploma of the Ministry of Defence in the light of Presidential Decree $n^{\circ} 4 / 2003$, of 27 December, and continue the restructuring of the military area and the modernisation of the FADM;

- Establish the necessary conditions for the Nampula Military Academy to begin functioning;

- Strengthen the training of soldiers for participation in humanitarian missions, mainly in rescuing the public in cases of natural disasters and other missions of public interest;

- Guarantee the continued operation of the CPLP Strategic Analysis Centre in Maputo, as a project to strengthen military cooperation between the member countries;

- Prepare and participate in military exercises and manoeuvres in the context of SADC and the CPLP;

- Participation at SADC and African Union level in the work of the technical teams appointed to draw up the legal instruments for the African Union and SADC Region Defence and Security sector;

- Guarantee the maintenance and functioning of the current five Military chancelleries (Spain, Malawi, Portugal, Russia and Tanzania) to ensure the continuity and expansion of the gains in the military area resulting from the close relations with the military of these countries, and open three more Military Chancelleries in South Africa, the USA and China;

- Incorporate 1,200 young people into the ranks of the FADM, for the necessary renewal of the military, ensuring the demobilisation of those conscripts incorporated in 2003;

- Ensure that classification and military inspection of the recruits are carried out during the various stages of their incorporation;

- Rehabilitate, equip and maintain degraded defence infrastructures, particularly military hospitals, barracks, and training centres, among others. 


\section{BUDGETARY POLICY}

Budgetary policy in 2005 will continue to be guided so as to achieve the objectives laid down in the government programme, which seeks to maintain sustainable and inclusive economic and social development, resting on increasing rigour and rationality in the use of public resources, and in ensuring public awareness to pursue the poverty reduction strategy.

To achieve this objective, it will be essential to maintain an environment of macro-economic stability characterised by reduction in the main macro-economic imbalances, by the continual mobilisation of internal and external resources to finance development programmes, and to ensure their sustainability.

Thus, for 2005, measures will be taken that seek to increase the availability of resources and improvement of the economic environment in order to allow our economy to compete with the outside world.

\begin{tabular}{|c|c|c|c|c|}
\hline \multirow{2}{*}{ STATE BUDGET - $109 \mathrm{MT}$} & \multicolumn{2}{|c|}{ Achieved Planned } & \multicolumn{2}{|c|}{$\%$ of GDP } \\
\hline & 2004 & 2005 & 2004 & 2005 \\
\hline EXPENDITURE & 32,507 & 44,932 & $25.9 \%$ & $31.0 \%$ \\
\hline Recurrent Expenditure & 18,899 & 22,604 & $15.1 \%$ & $15.6 \%$ \\
\hline Capital Expenditure & 12,881 & 19,001 & $10.3 \%$ & $13.1 \%$ \\
\hline Net Loans & 727 & 3,326 & $0.6 \%$ & $2.3 \%$ \\
\hline FUNDING: & 32,507 & 44,932 & $25.9 \%$ & $31.0 \%$ \\
\hline Revenue & 16,562 & 22,226 & $13.2 \%$ & $15.3 \%$ \\
\hline Grants & 10,918 & 11,544 & $8.7 \%$ & $8.0 \%$ \\
\hline Transf. BM HIPC & 484 & 368 & $0.4 \%$ & $0.3 \%$ \\
\hline Net External Credit & 4,791 & 7,875 & $3.8 \%$ & $5.4 \%$ \\
\hline Net Internal Credit & -248 & 2,919 & $-0.2 \%$ & $2.0 \%$ \\
\hline
\end{tabular}

Public sector reform and administrative and financial decentralisation should constitute strong challenges for 2005. Making operational the Law on Local State Bodies, which transforms districts into budgetary units, consolidating implementation of the Law on State Financial Administration, and modernization of our administrative apparatus will be fundamental for greater fiscal discipline, transparency, efficiency and effectiveness in the use of public resources. 


\section{State Revenue}

State revenue in 2005 could reach 22,174.1 billion meticais, equivalent to about $15.3 \%$ of GDP. Of this sum, $21,492.4$ billion meticais is recurrent revenue, while 681.8 billion meticais is capital revenue. The figure for recurrent revenue means an increase of $30.5 \%$ over what was collected in 2004 . This forecast rests on assumptions of a favourable economic growth, broadening of the tax base, and improvements in the efficiency of the tax administration.

The recurrent revenue of $21,492.4$ billion meticais envisaged is equivalent to about $14.8 \%$ of GDP, which is 0.8 percentage points (pp) higher then the previous year. Included in this category are fiscal revenue, non-fiscal revenue and earmarked revenue.

\begin{tabular}{lrrrr|}
\hline & \multicolumn{3}{c}{ Achieved Planned } & \multicolumn{2}{c|}{ of GDP } \\
\multicolumn{1}{c}{ STATE REVENUE - $\mathbf{1 0}^{\mathbf{9}} \mathbf{M T}$} & $\mathbf{2 0 0 4}$ & $\mathbf{2 0 0 5}$ & $\mathbf{2 0 0 4}$ & $\mathbf{2 0 0 5}$ \\
\hline & & & & \\
FISCAL REVENUE & 14,435 & 18,409 & $11.5 \%$ & $12.7 \%$ \\
$\quad$ Taxes on income & 3,470 & 4,694 & $2.8 \%$ & $3.2 \%$ \\
Taxes on goods and services & 7,575 & 9,520 & $6.0 \%$ & $6.6 \%$ \\
Taxes on foreign trade & 2,218 & 2,765 & $1.8 \%$ & $1.9 \%$ \\
Other taxes & 1,172 & 1,430 & $0.9 \%$ & $1.0 \%$ \\
NON-FISCAL REVENUE & 779 & 1,388 & $0.6 \%$ & $1.0 \%$ \\
EARMARKED REVENUE & 1,290 & 1,747 & $1.0 \%$ & $1.2 \%$ \\
CAPITAL REVENUE & 59 & 682 & $0.0 \%$ & $0.5 \%$ \\
TOTAL & $\mathbf{1 6 , 5 6 2}$ & $\mathbf{2 2 , 2 2 6}$ & $\mathbf{1 3 . 2} \%$ & $\mathbf{1 5 . 3 \%}$ \\
\hline
\end{tabular}

Non-fiscal revenue could reach 1,411.9 billion meticais, about $1.0 \%$ of GDP, an increase of $0.4 \mathrm{pp}$ compared with the previous year. This increase is mainly due to the inclusion in this heading of the own revenue of district administrations and central institutions.

Earmarked revenue will record a major increase in 2005, compared with 2004, rising from 282.3 to $1,673.6$ billion meticais. This increase results from application of the decree approving the fuel tax regulations, and increased collection of this revenue by the fiscal administration. When compared to GDP, this revenue rises from $0.2 \%$ of GDP in 2004 to $1.2 \%$ in 2005 .

Capital revenue should increase substantially, due to concessions for prospection and exploitation of the country's mineral resources, particularly of the Moatize coal. In this area the government always took into account the need to guarantee sustainable exploitation. Thus, in 2005 the collection of 681.8 billion meticais is envisaged, against 188 billion collected in 2004. 
To attain these revenue targets, various activities will be undertaken, among which the following stand out:

In the area of internal organisation:

- Modernise the apparatus of the Tax Administration, through setting up the General Tax Directorate (DGI);

- Consolidate the system of attributing the Single Tax Identification Number (NUIT) which will allow improvements in controlling compliance with the obligations of taxpayers, and of monitoring the various economic activities, resulting in an increase in revenue;

- Apply the system of automatic daily transfer of revenue collected to the Treasury, in order to improve management of the State Treasury;

- Consolidate the functioning of the Tax Training Centre with the purpose of upgrading the skills of tax administration staff, seeking improved attendance to taxpayers;

- Rescale fiscal areas and create new fiscal areas, as well as setting up the Taxpayers' Information Service, which seeks to provide more information to taxpayers and make it easier for them to fulfill their fiscal obligations;

- Computerise taxes in order to improve management and simplifying procedures in the provision of services to taxpayers by the tax administration;

- Implement specific legislation that regulates the functioning of the tax administration and its staff table;

- Computerise tax processes;

- Make the fiscal tribunals autonomous.

\section{In the area of customs supervision}

- Apply the new procedures concerning the international transit of merchandise, which will guarantee greater control capacity;

- Step up anti-contraband operations in all parts of the country;

- Continue to make sure that the infrastructures of the central and northern regions are adequate for installing the VSAT communications system and RENA (computerised national customs network);

- Hold post-customs clearance audits in the framework of implementing the merchandise valuation agreement of the World Trade Organisation;

- Support rapid installation of Scanners in the main ports and terminals and in establishing the Ressano Garcia dry port, in order to ensure security and facilitation of trade; 
- Formulate and implement a programme of taxpayer education, so that taxpayers voluntarily comply with their fiscal obligations;

- Analysis and continual assessment of systems with a view to simplifying procedures;

- Coordination with other Mozambican and regional institutions in order to protect the health of staff and their families, as a priority measure in preventing and fighting against HIVIAIDS.

\section{In the area of infrastructures}

- In Tete - rehabilitate the Zóbue frontier post, and build an international road terminal in Tete city;

- In Niassa - rehabilitate and build residences in Mandimba;

- Start construction and rehabilitation work in the following places:

$>$ In Maputo province - build a border complex at Ponta do Ouro;

$>$ In Cabo Delgado - construct the building, offices and housing at the Namoto Fiscal Post;

$>$ In Nampula, start the 2nd phase of building the Nacala residential complex.

\section{In the area of international cooperation and facilitating legitimate trade}

- Align national legislation to international conventions, particularly the Kyoto Convention of the simplification of customs procedures;

- Facilitate regional trade by implementing bilateral agreements with the countries of SADC, particularly with Zimbabwe;

- Strengthen cross-border security by revising and implementing memoranda of understanding with the neighbouring countries;

- Consolidate mechanisms of cooperation and consultation with the countries of the region in the exchange of information capable of restraining tax evasion in inter-regional trade.

\section{State expenditure}

Total state expenditure should reach $46,731.6$ billion meticais. Of this sum, $41,553.76$ billion meticais constitutes the effective state expenditure to implement the activities envisaged in the Economic and Social Plan and 5,177.84 billion meticais concern financial operations - that is, they are resources destined to amortise public debt (internal and external) and channelled to public companies, or companies with a state holding, through agreements of retrocession. 
Staff costs consume the greatest part of total recurrent expenditure total. They represent $48.8 \%$ of total recurrent costs. They are followed by expenditure on goods and services, with $23.5 \%$ and current transfers with $17.7 \%$.

\begin{tabular}{lrrrr|}
\hline & \multicolumn{3}{c}{ Achieved Planned } & \%of GDP \\
\multicolumn{1}{c}{ RECURRENT EXPENSES - $\mathbf{1 0}^{\mathbf{9}} \mathbf{\text { MT }}$} & 2004 & $\mathbf{2 0 0 5}$ & $\mathbf{2 0 0 4}$ & $\mathbf{2 0 0 5}$ \\
\hline Staff expenditure & 9,195 & 11,045 & $7.3 \%$ & $7.6 \%$ \\
Goods and services & 3,966 & 5,308 & $3.2 \%$ & $3.7 \%$ \\
Debt servicing & 1,213 & 1,284 & $1.0 \%$ & $0.9 \%$ \\
Current transfers & 3,555 & 4,003 & $2.8 \%$ & $2.8 \%$ \\
Subsidies & 208 & 222 & $0.2 \%$ & $0.2 \%$ \\
Other recurrent expenditure & 581 & 603 & $0.5 \%$ & $0.4 \%$ \\
Past financial years & 0 & 0 & $0.0 \%$ & $0.0 \%$ \\
Capital Expenditure & 126 & 0 & $0.1 \%$ & $0.0 \%$ \\
Complementary period & 0 & 0 & $0.0 \%$ & $0.0 \%$ \\
TOTAL & $\mathbf{1 8 , 8 9 9}$ & $\mathbf{2 2 , 6 0 4}$ & $\mathbf{1 5 . 1 \%}$ & $\mathbf{1 5 . 6 \%}$ \\
TOTAL EXCL. DEBT SERVICING & $\mathbf{1 7 , 6 8 6}$ & $\mathbf{2 1 , 3 2 1}$ & $\mathbf{1 4 . 1 \%}$ & $\mathbf{1 4 . 7 \%}$ \\
\hline
\end{tabular}

Staff costs should reach $11,051.9$ billion meticais, about $7.6 \%$ of GDP, which is a growth of about $0.1 \mathrm{pp}$ of GDP compared with 2004. This growth, as mentioned above, is intended to face the costs inherent in admitting staff, in promotions, progression along career structures, and wage increases resulting from the negotiations between the government, employers and trade unions held every year.

The goods and services line will record a real increase in comparison with 2004, reaching about $3.7 \%$ as against $3.0 \%$ of GDP in 2004. In absolute terms, this sum is $5,319.7$ billion meticais, and is intended to deal with the physical expansion of the main areas of action in the fight against poverty, including Education, Health and Infrastructures. Apart from the costs arising from the capital expenditure under way in these areas, this sum is intended to finance the goods and services that are indispensable for the functioning of existing public institutions, such as schools and hospitals.

In 2005, debt servicing should reach 1,283.7 billion meticais, compared with $1,228.0$ billion in 2004 , which is a slight drop of $0.1 \%$ of GDP. This trend is the result of the government's policy to pursue budgetary sustainability, which involves controlling the levels of the state's indebtedness, and the consequent debt servicing.

For 2005, public capital expenditure is fixed at $18,927.4$ billion meticais, corresponding to $13.1 \%$ of GDP, a growth of $2.0 \mathrm{pp}$ compared with the previous year. Of this sum, $30.1 \%$ is funded by internal resources, and the remaining $69.9 \%$ by external resources provided directly to public investment projects. 


\begin{tabular}{lrrrr|}
\hline \multirow{2}{*}{ CAPITAL EXPENDITURE - } & \multirow{2}{*}{$\mathbf{1 0}^{\mathbf{9}} \mathbf{M T}$} & $\mathbf{2}$ Achieved Planned & \multicolumn{2}{c|}{$\%$ of GDP } \\
\hline Internal Financing & & 2005 & $\mathbf{2 0 0 4}$ & $\mathbf{2 0 0 5}$ \\
External Financing & 4,074 & 5,763 & $3.3 \%$ & $4.0 \%$ \\
$\quad$ Grants & 8,807 & 13,239 & $7.0 \%$ & $9.1 \%$ \\
$\quad$ Loans & 6,356 & 7,573 & $5.1 \%$ & $5.2 \%$ \\
Complementary Period & 2,451 & 5,666 & $2.0 \%$ & $3.9 \%$ \\
TOTAL & & & & \\
\hline
\end{tabular}

\section{Implementation of expenditure in the PARPA priority sectors}

During the period 2000-2004, on average the government allocated about two thirds of total available resources to the PARPA priority sectors. For the term of office now starting, continuation of the same volume of resources for these sectors is expected. 
-103 -

ECONOMIC AND SOCIAL PLAN FOR 2005

\begin{tabular}{|c|c|c|c|}
\hline \multirow[b]{3}{*}{ Total expenditure (recurrent and capital) } & \multirow{2}{*}{$\begin{array}{l}2003 \\
\text { CGE }\end{array}$} & \multirow{2}{*}{$\begin{array}{l}2004 \\
\text { Achieved }\end{array}$} & \multirow{2}{*}{$\begin{array}{c}2005 \\
\text { Plan }\end{array}$} \\
\hline & & & \\
\hline & $26,821.3$ & $31,780.2$ & $41,605.5$ \\
\hline Interest on public debt & $1,318.2$ & $1,212.9$ & $1,283.7$ \\
\hline Total expenditure excl. Debt interest & $25,503.2$ & $30,567.2$ & $40,321.9$ \\
\hline \multicolumn{4}{|l|}{ Priority Areas } \\
\hline Education & $5,149.7$ & $6,638.9$ & $7,480.8$ \\
\hline General Education & $4,345.1$ & $5,671.2$ & $5,789.5$ \\
\hline Higher education & 804.6 & 967.7 & $1,691.3$ \\
\hline Health & $2,709.0$ & $3,495.8$ & $4,999.5$ \\
\hline HIVIAIDS & 80.5 & 127.1 & 267.6 \\
\hline Infrastructures & $3,540.4$ & $3,495.8$ & $7,528.8$ \\
\hline Roads & $2,816.2$ & $2,796.7$ & $5,703.3$ \\
\hline Water and Public Works & 724.2 & 699.2 & $1,825.5$ \\
\hline Agriculture and Rural Development & $1,260.6$ & $1,366.5$ & $1,684.3$ \\
\hline Governance, security and judicial system & $2,387.1$ & $2,987.3$ & $3,893.0$ \\
\hline Governance and public administration & 482.8 & 476.7 & 856.3 \\
\hline Security and public order & $1,421.5$ & $1,779.7$ & $2,072.9$ \\
\hline Judicial system & 482.8 & 730.9 & 963.8 \\
\hline Other priority sectors & $1,046.0$ & $1,048.7$ & 896.4 \\
\hline Social action & 187.7 & 190.7 & 258.4 \\
\hline Labour and employment & 80.5 & 127.1 & 132.9 \\
\hline Mineral Resources and energy & 777.8 & 730.9 & 505.1 \\
\hline TOTAL priority areas & $16,173.3$ & $19,160.3$ & $26,750.2$ \\
\hline \multicolumn{4}{|c|}{ As $\%$ of total expenditure (exl. Financial operations and interest payments) } \\
\hline Education & $20.2 \%$ & $21.7 \%$ & $18.6 \%$ \\
\hline General education & $17.0 \%$ & $18.6 \%$ & $14.4 \%$ \\
\hline Higher education & $3.2 \%$ & $3.2 \%$ & $4.2 \%$ \\
\hline Health & $10.6 \%$ & $11.4 \%$ & $12.4 \%$ \\
\hline HIVIAIDS & $0.3 \%$ & $0.4 \%$ & $0.7 \%$ \\
\hline Infrastructures & $13.9 \%$ & $11.4 \%$ & $18.7 \%$ \\
\hline Roads & $11.0 \%$ & $9.1 \%$ & $14.1 \%$ \\
\hline Water and public works & $2.8 \%$ & $2.3 \%$ & $4.5 \%$ \\
\hline Agriculture and rural development & $4.9 \%$ & $4.5 \%$ & $4.2 \%$ \\
\hline Governance, security and judicial system & $9.4 \%$ & $9.8 \%$ & $9.7 \%$ \\
\hline Governance and public administration & $1.9 \%$ & $1.6 \%$ & $2.1 \%$ \\
\hline Security and public order & $5.6 \%$ & $5.8 \%$ & $5.1 \%$ \\
\hline Judicial system & $1.9 \%$ & $2.4 \%$ & $2.4 \%$ \\
\hline Other priority sectors & $4.1 \%$ & $3.4 \%$ & $2.2 \%$ \\
\hline Social action & $0.7 \%$ & $0.6 \%$ & $0.6 \%$ \\
\hline Labour and employment & $0.3 \%$ & $0.4 \%$ & $0.3 \%$ \\
\hline Mineral resources and energy & $3.0 \%$ & $2.4 \%$ & $1.3 \%$ \\
\hline PARPA priority sectors & $63.4 \%$ & $62.7 \%$ & $66.3 \%$ \\
\hline
\end{tabular}

\section{Note: $\mathrm{CGE}=$ General State Accounts}

The table shows the evolution of expenditure in the priority sectors and a forecast for 2005 . As may be noted, total expenditure in the priority sectors will amount to $66.3 \%$ of total expenditure, excluding debt servicing and financial operations.

The largest sums in running costs are concentrated in the priority areas for fighting poverty. Because of the large number of staff they employ, education and 
health account for the greatest amount of resources for staff and for other costs required for the operations of schools and hospitals.

The following graph shows the distribution of total expenditure among the priority sectors:

Composition of expenditure on the PARPA priority sectors, 2005

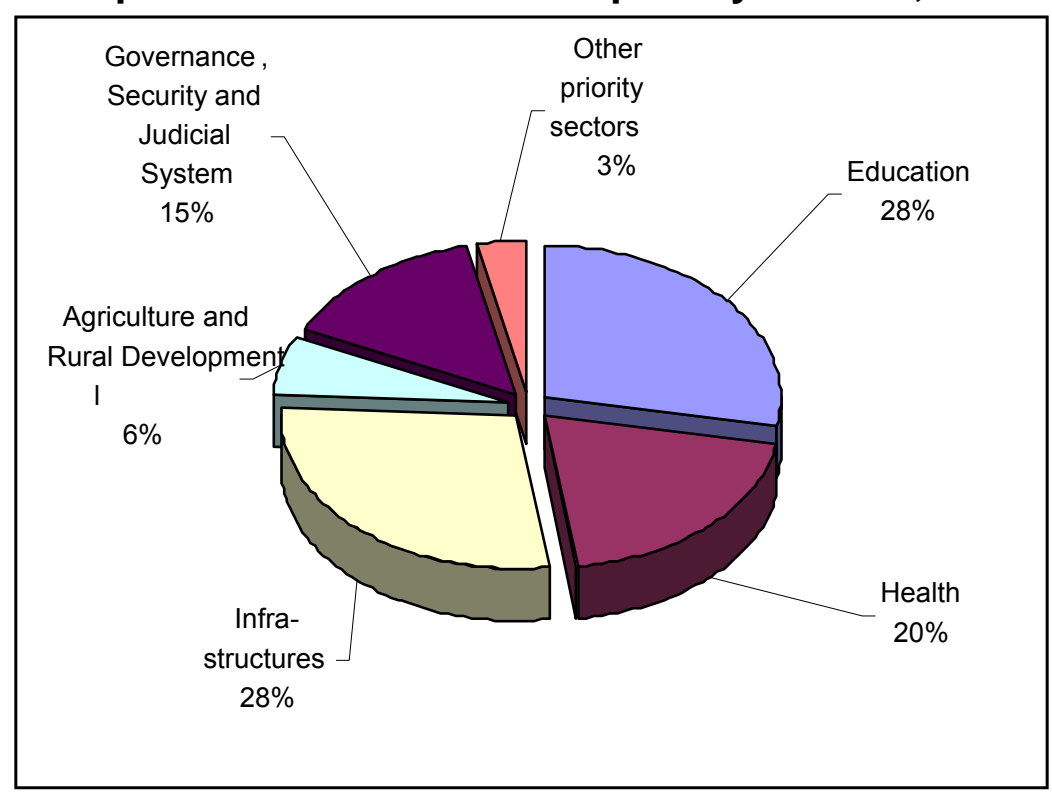

Budgetary balance sheet

\begin{tabular}{|c|c|c|c|c|}
\hline \multirow[b]{2}{*}{ BUDGETARY FRAMEWORK $10^{9}$ MT } & \multirow{2}{*}{$\begin{array}{l}\text { Result } \\
2004\end{array}$} & \multirow{2}{*}{$\begin{array}{c}\text { Planned } \\
2005 \\
\end{array}$} & \multicolumn{2}{|c|}{$\%$ of GDP } \\
\hline & & & 2004 & 2005 \\
\hline REVENUE & 16,562 & 22,226 & $13.2 \%$ & $15.3 \%$ \\
\hline RECURRENT EXPENDITURE & 18,899 & 22,604 & $15.1 \%$ & $15.6 \%$ \\
\hline CAPITAL EXPENDITURE & 12,881 & 19,001 & $10.3 \%$ & $13.1 \%$ \\
\hline NET LOANS & 727 & 3,326 & $0.6 \%$ & $2.3 \%$ \\
\hline OTHER REVENUE (-)/EXPENDITURE (+) & 0 & 0 & $0.0 \%$ & $0.0 \%$ \\
\hline TOTAL EXPENDITURE & 31,780 & 41,606 & $25.4 \%$ & $28.7 \%$ \\
\hline TOTAL EXPENDITURE INC. NET LOANS. & 32,507 & 44,932 & $25.9 \%$ & $31.0 \%$ \\
\hline CURRENT BALANCE & $-2,337$ & -379 & $-1.9 \%$ & $-0.3 \%$ \\
\hline OVERALL DEFICIT BEFORE GRANTS & $-15,945$ & $-22,706$ & $-12.7 \%$ & $-15.7 \%$ \\
\hline GRANTS & 10,918 & 11,544 & $8.7 \%$ & $8.0 \%$ \\
\hline OVERALL DEFICIT AFTER GRANTS & $-5,027$ & $-11,162$ & $-4.0 \%$ & $-7.7 \%$ \\
\hline TRANSFER FROM BM TO HIPC & 484 & 368 & $0.4 \%$ & $0.3 \%$ \\
\hline LOANS & 4,791 & 7,875 & $3.8 \%$ & $5.4 \%$ \\
\hline Disbursements & 5,376 & 8,696 & $4.3 \%$ & $6.0 \%$ \\
\hline Amortisations & -585 & -820 & $-0.5 \%$ & $-0.6 \%$ \\
\hline NET INTERNAL CREDIT & -248 & 2,919 & $-0.2 \%$ & $2.0 \%$ \\
\hline
\end{tabular}




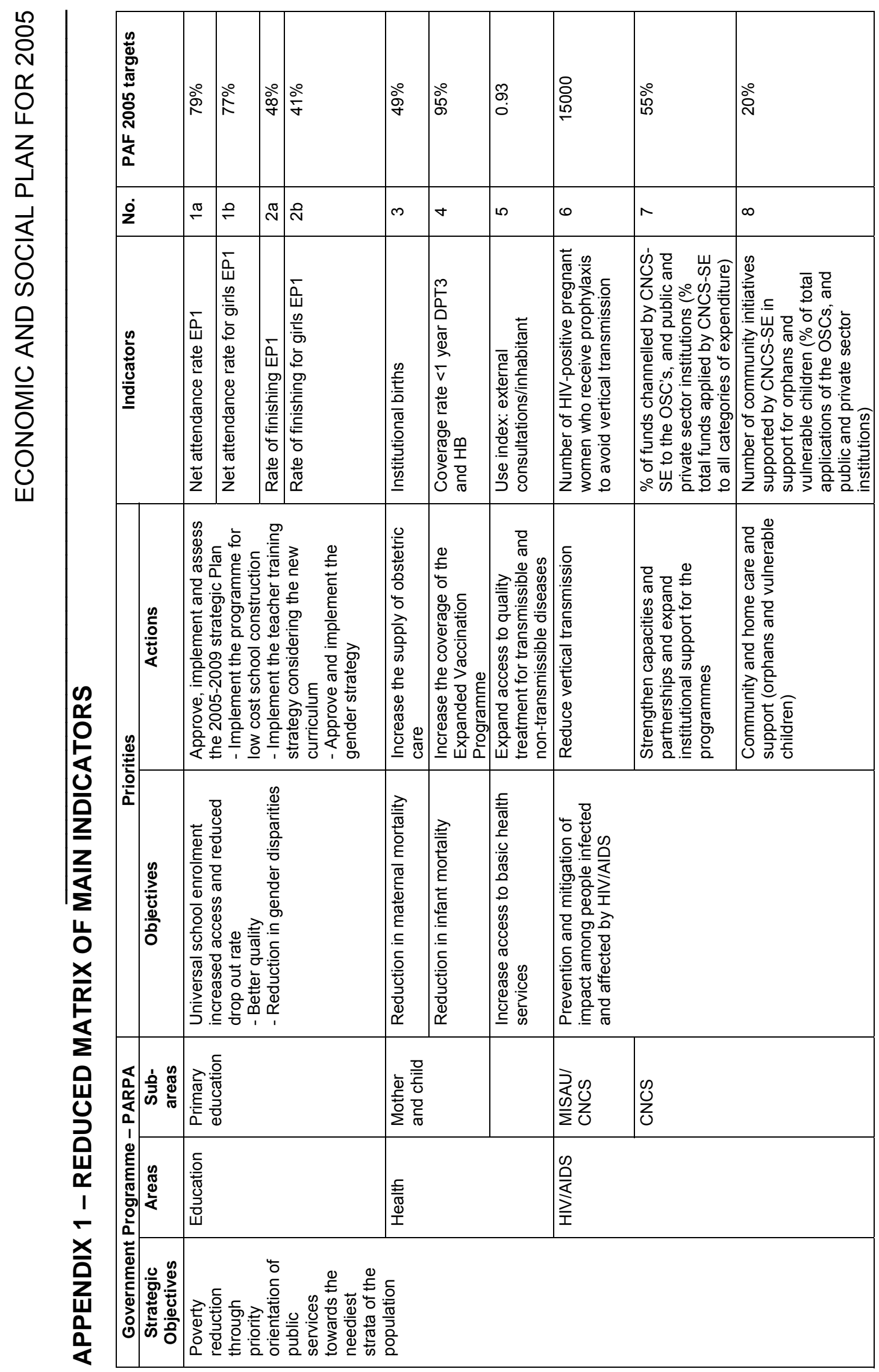




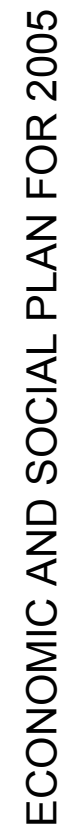

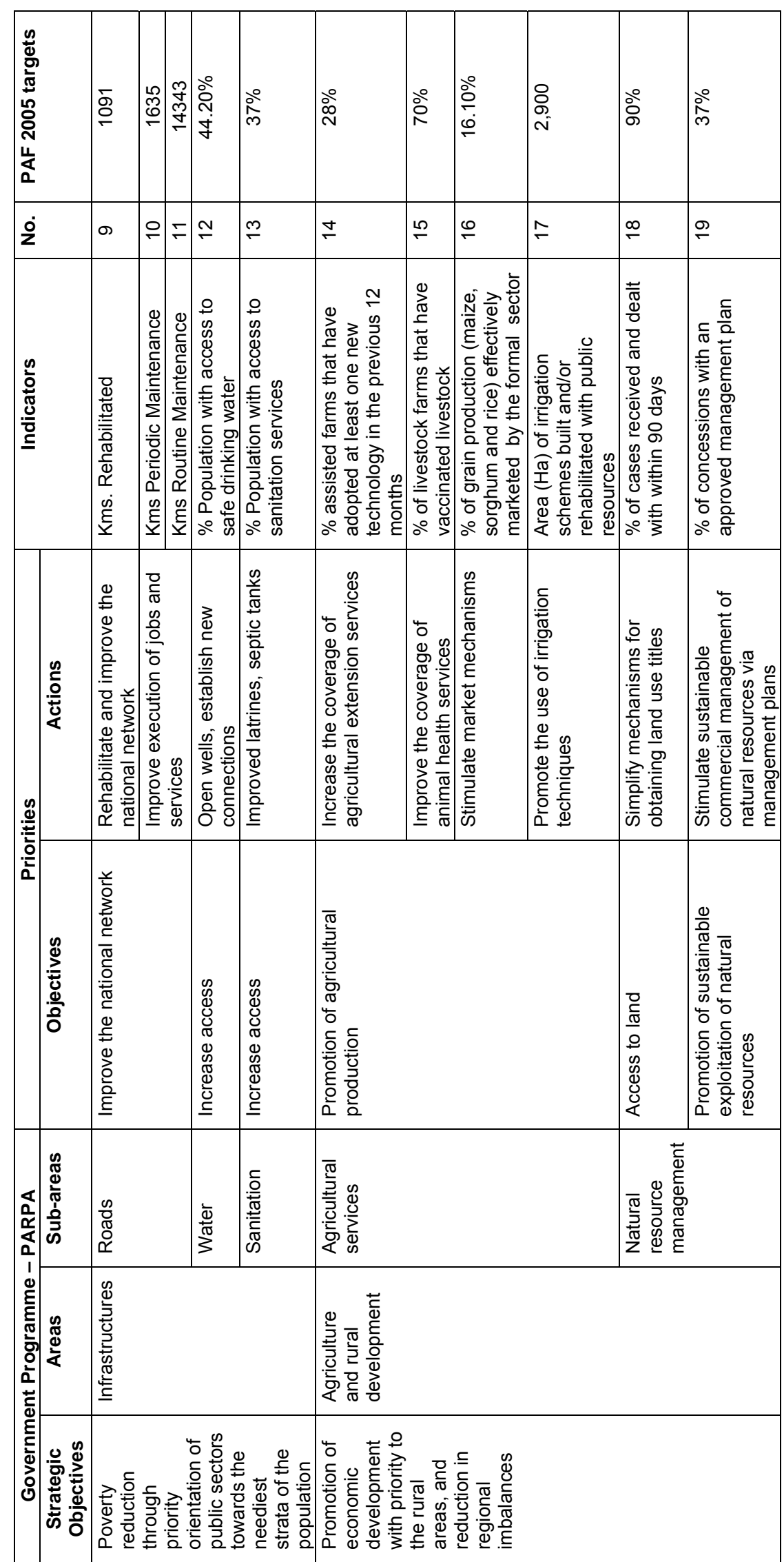




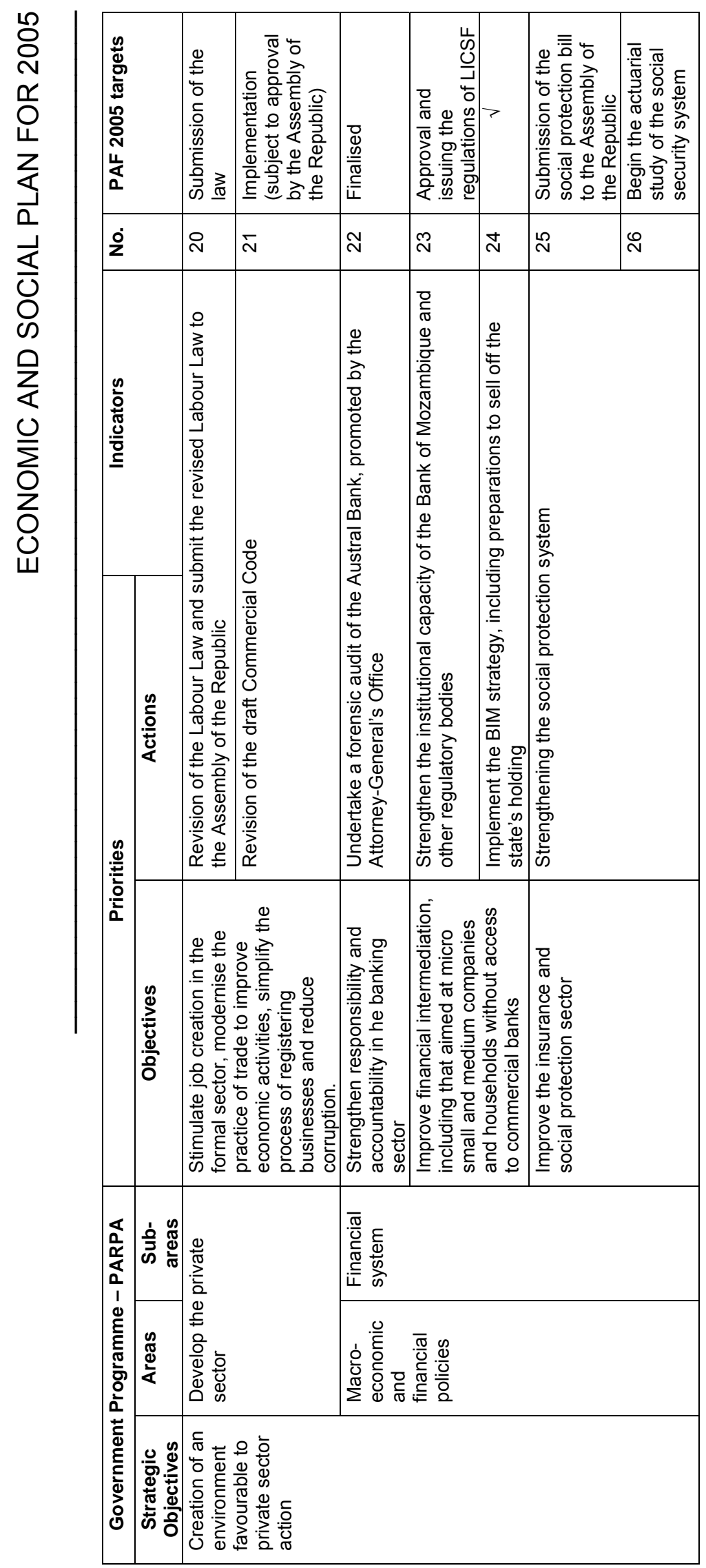




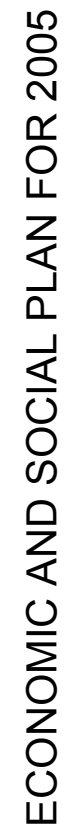

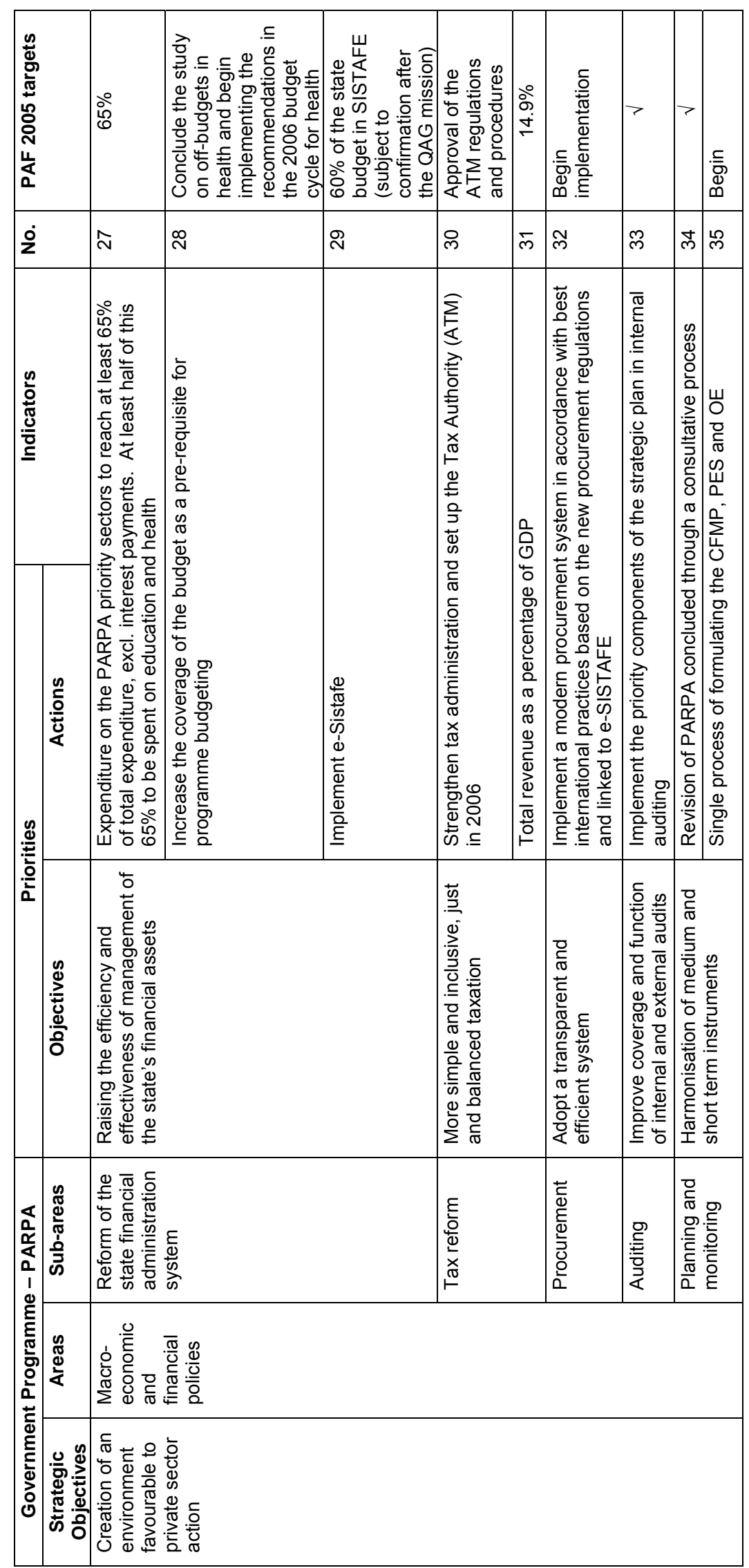




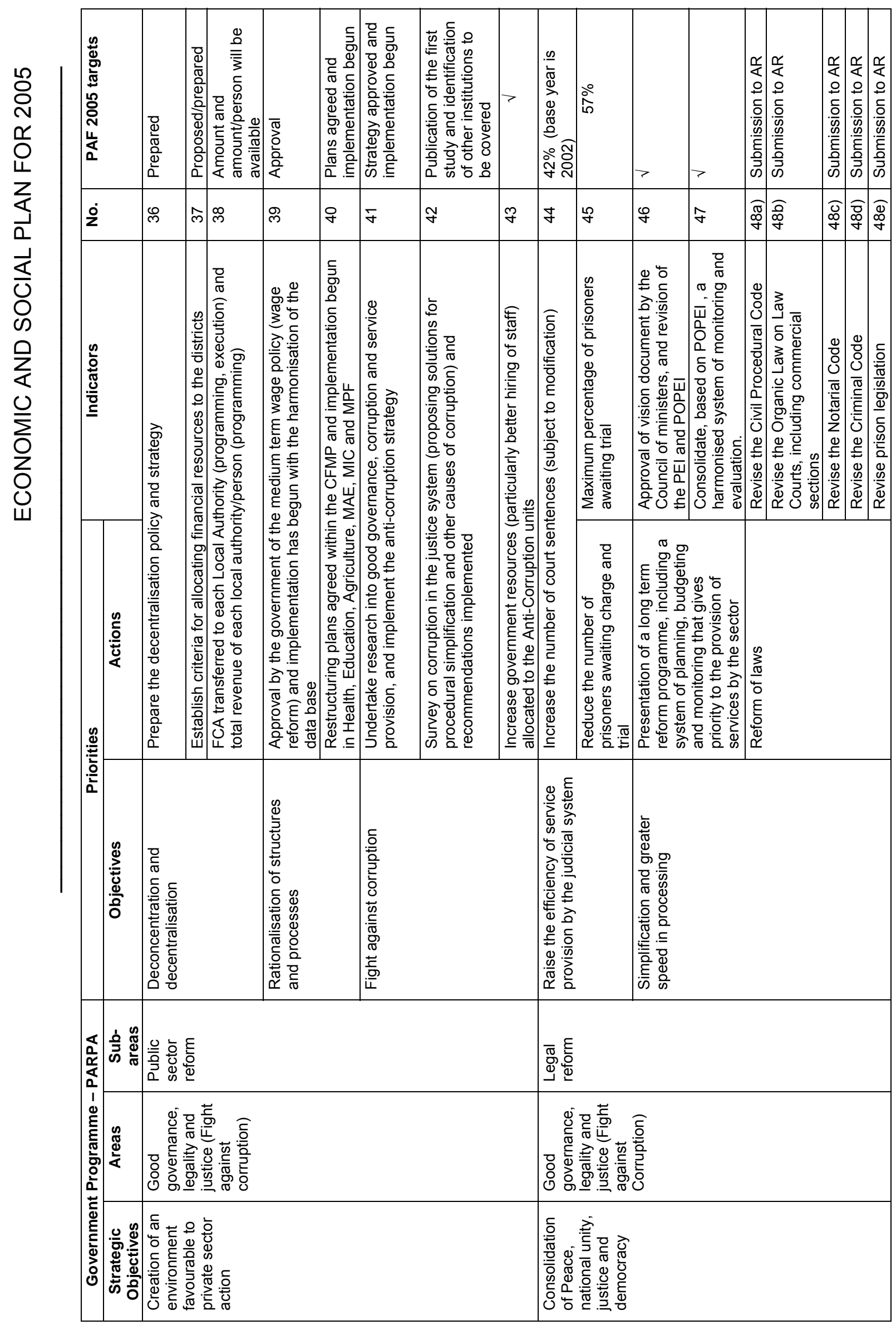

